\title{
COMPARAÇÃO DE DIETAS ARTIFICIAIS PARA A CRIAÇÃO DE Diatraea saccharalis (FABRICIUS, 1794) (Lepidoptera - Pyralidae)
}

\author{
LAILA HERTA MIHSFELDT \\ Engenheiro Agrônomo
}

Orientador: Dr. JOSÉ ROBERTO POSTALI PARRA

Dissertaçāo apresentada à Escola Superior de Agricultura "Luiz de Queiroz", da Universidade de Sāo Paulo, para obtençāo do título de Mestre em Ciências Biológicas, Área de Concentração: Entomologia.

$P \mid R A C I C A B A$

Estado de São Paulo - Brasil

Abril - 1985 


\section{AGRNECIMENTOS}

Ao Dr. José Roberto Postali Parra, Professor Adjunto do Depar tamento de Entomologia, da Escola Superior de Agricultura "Luiz de Queiroz", da Universidade de São Paulo, pela criteriosa e objetiva orientação na elaboração do presente trabalho;

A Financiadora de Estudos e Projetos (FINEP), pelo financiamento da pesquisa;

Ao Conselho Nacional de Pesquisa e Desenvolvimento Cientifico e Tecnológico (CNPq) pela concessão de uma bolsa-de - estudos para realização do Curso de Pós-Graduação;

Ao Dr. Raul Machado, professor assistente doutor do Departamento de Zoologia da ESALQ, pela análise eletroforêtica e orientação na interpretação da mesma;

Ao Dr. Geraldo A. Tosello, professor adjunto do Departamento de Genética da ESALQ, pelo fornecimento de sementes dos ge nötipos de milho e informasões sobre suas caracteristicas genëticas; 
Ao Dr. William J. Silva, do Departamento de Genética e Evolução do Instituto de Biologia, da Universidade Estadual de Campinas, pelo fornecimento de sementes do genótipo de milho 'Nutrimaiz';

A Engọ Agrọ Drạ Marinéia de Lara Haddad, pelo apoio estatístị co;

Aos Professores do Curso de Pös-Graduação em Entomologia da Escola Superior de Agricultura "Luiz de Queiroz", pelos ensinamentos transmitidos;

A Empresa Brasileira de Pesquisa Agropecuāria (EMBRAPA), atra vês do Centro Nacional de Pesquisa - Arroz, Feijão (CNPAF), pelas facilidades concedidas na fase final do presente trabalho;

Ao Engọ Agrọ Hélio José Castilho, M.S., responsável pela laboratōrio de Entomologia da Cia. Industrial e Agrícola de San ta Bärbara d'Oeste, SP, pelo fornecimento de insetos;

Aos amigos César Pagotto Stein e Irineu Lobo Rodrigues Filho, pe 10 apoio na condução deste trabalho e, especialmente, pela amizade e carinho recebidos; 
Aos colegas do Curso de Pós-Graduação, especialmente os amigos A ci Enimar Loeck, Ervino Bleicher, Josē Francisco da Silva Martins e Joselito Souza Correia, pela amizade e companhefrismo;

E a todos que direta ou indiretamente auxiliaram na condução do presente trabalho. 


\section{INDICLE}

LISTA DE TABELAS.................... ix

LISTA DE FIGURAS..................... xviii

RESUMO $\ldots \ldots \ldots \ldots \ldots \ldots \ldots \ldots \ldots \ldots \ldots \ldots \ldots \ldots \ldots \ldots \ldots$

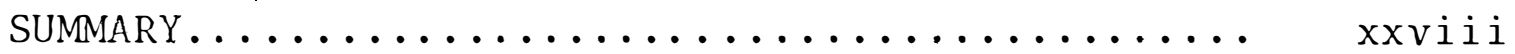

1. INTRODUCAO $\ldots \ldots \ldots \ldots \ldots \ldots \ldots \ldots \ldots \ldots \ldots \ldots \ldots \ldots \ldots$

2. REVISÃO DE LiteratURA.................... 3

3. MATERIAL E METODOS...................... 13

3.1. Comparação de parâmetros biológicos de 0 . sac charalis em diferentes dietas artificiais...

3.1.1. 1ạ Etapa - fontes protéicas variáveis:

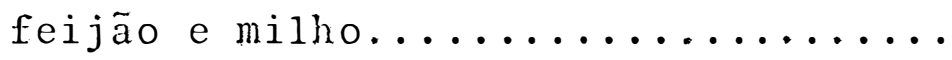

3.1.2. 2a Etapa - fontes protéicas variảveis: (germe de trigo, soja, levedura, caseína,fe jão, farelo de trigo).............

3.1.3. 3ạ Etapa - fontes protéicas variáveis:

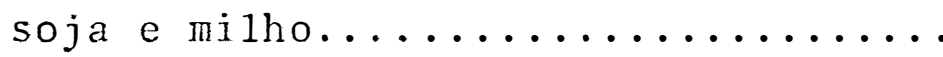

3.1.4. 4ạ Etapa - fonte protéica variável:m

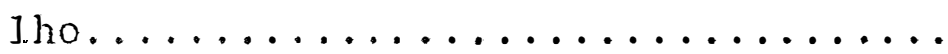

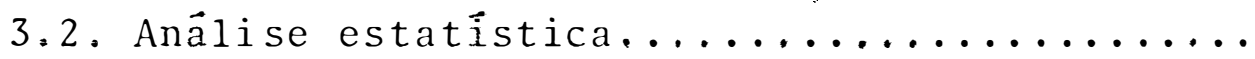

3.3. Comparação das 4 dietas selecionadas....... 
.vii.

Página

3.3.1. Número de ínstares larvais......... 36

3.3.2. Tabela de vida de fertilidade....... 37

3.3.3. Nutrição quantitativa - consumo e uti 1ização do alimento............. 38

3.3.4. Anälise protéica.............. 42

3.3.4.1. Método de Kjedah1........ 42

3.3 .4 .2 . Eletroforese........... 42

3.3.5. Custo das 4 dietas selecionadas...... 43

3.3.6. Anāise estatistica............. 43

4. RESULTADOS E DISCUSSÃO................. 46

4.1. 1ạ Etapa - fontes protéicas variáveis: fei-

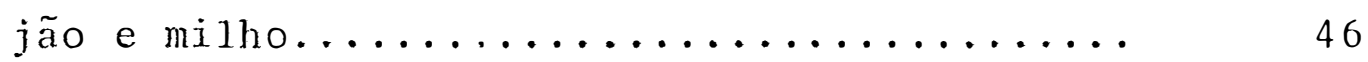

4.2. 2ạ Etapa - fontes protéicas variáveis: germe de trigo, soja, levedura, caseína, feijão e

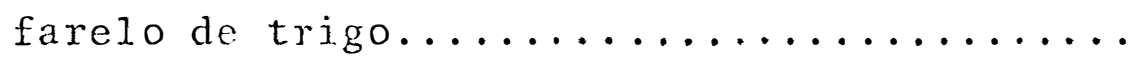

4.3. 3ạ Etapa - fontes nrotéicas variáveis: soja e $\operatorname{milho\ldots \ldots \ldots \ldots \ldots \ldots \ldots \ldots \ldots \ldots \ldots \ldots } 63$

4.4. 4ạ Etapa - fonte protéica variável: milho... 70

4.5. Comparação das 4 dietas selecionadas....... 77

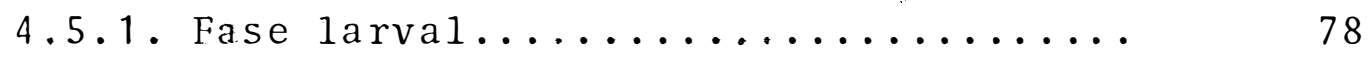

4.5.1.1. Duração e viabilidade...... 78

4.5.1.2. Número e duração dos insta res larvais nas 4 dietas selecionadas.................... 


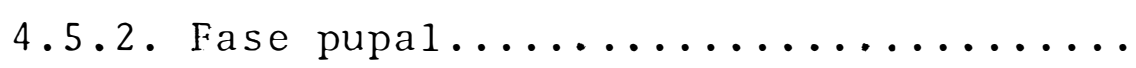

4.5.3. Fase adulta: longevidade, período de pré-oviposição, nümero de ovos por fê mea e porcentagem de deformação.....

4.5.4. Fase de ovo: período de incubação e viabilidade..................

4.5.5. Efeito fagoestimulante e viabilidade $\operatorname{tota} 1 \ldots \ldots \ldots \ldots \ldots \ldots \ldots$

4.5.6. Tabela de vida de fertilidade.......

4.5.7. Consumo e utilização do alimento nas 4 dietas selecionadas.............

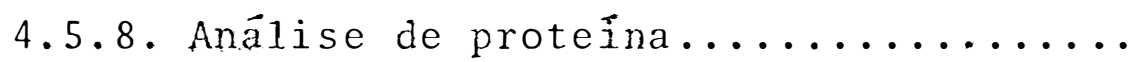

4.5.8.1. Método de Kjedah1.........

4.5.9. Custo das 4 dietas selecionadas..... 


\section{LISTA DE TABELAS}

TABELAA

Pāgina

1 Composição da dieta de HENSLEY e HAMMOND $(1968) \ldots \ldots \ldots \ldots \ldots \ldots \ldots \ldots \ldots \ldots \ldots \ldots \ldots \ldots \ldots \ldots \ldots \ldots \ldots \ldots$

2 Composição da dieta utilizada nos labora tórios da Usina Santa Bārbara, em Santa Bārbara d'Oeste, $s ! \ldots \ldots \ldots \ldots \ldots \ldots$

3 Composição da dieta de KASTEN et alii $(1978) \ldots \ldots \ldots \ldots \ldots \ldots \ldots \ldots \ldots \ldots \ldots \ldots \ldots \ldots \ldots \ldots \ldots \ldots$

4 Composição da dieta à base de milho híbrido moído e levedura.............

5 Composição da dieta à base de farinha de soja e germe de trigo (Dieta A).......

6 Composição da dieta à base de germe de trigo e farinha de soja (BERGER, 1963) (Dieta $B) \ldots \ldots \ldots \ldots \ldots \ldots \ldots \ldots$

7 Composição da dieta à base de germe de

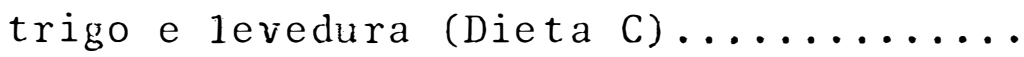


8 Composição da dieta à base de germe de trigo e caseína (USDA, 1976) (Dieta D)..

9 Composição da dieta à base de feijão 'Câ rioca', germe de trigo e levedura (USDA,

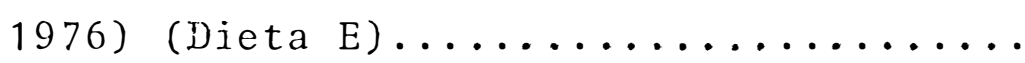

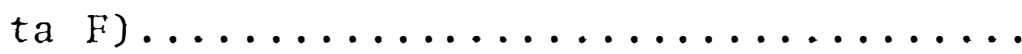

11 Composição da dieta à base de germe de trigo e farinha de soja (USDA, 1976) (Dieta $G) \ldots \ldots \ldots \ldots \ldots \ldots \ldots \ldots \ldots$

12 Composição da dieta à base de farinha de soja, farelo de trigo e levedura (1)ieta

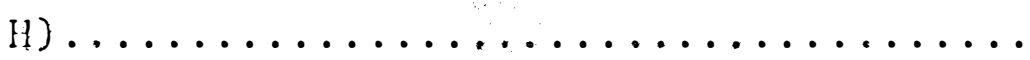

13 Composição da deita à base de farinha de

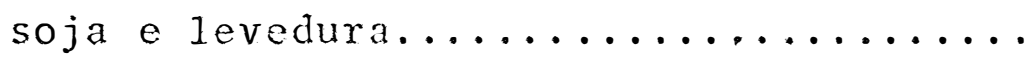

14 Composição da dieta à base de farinha de milho, germe de trigo e levedura (modifi cação proposta por BUES e POITOUT (1970) ..... 
15 Porcentagem de proteina total e lisina das diferentes variedades de milho utilizadas nas dietas para criação de $D$. saccharalis.

16 Planilha utilizada para anotações dos dados para o cálculo de perda d'água da alí-

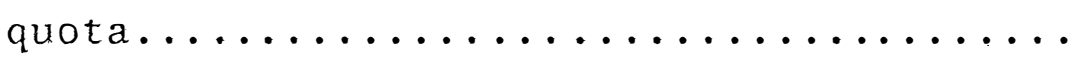

17 Planilha utilizada para anotações dos dados de consumo e utilizaşão de alimentos

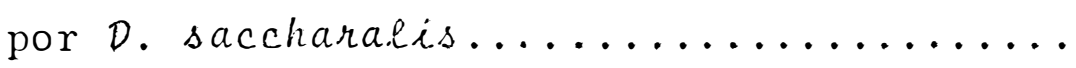

18 Duração média do período larval (machos e fêmeas) de $D$. saccharalis criada em dietas artificiais, incluindo 6 genötipos de feijão e um híbrido de milho e porcentual de contaminas̃ão por fungos. Temperatura: $25 \pm$ $10 \mathrm{C}$; UR: $70 \pm 10 \%$; fotofase: 14 horas......

19 Peso médio de pupas (machos e fêmeas) criada em dietas artificiais incluindo 6 genötipos de feijão e um híbrido de milho. Temperatura: $25 \pm 1{ }^{\circ} \mathrm{C}$; UR: $70 \pm 10 \%$; fotofase:

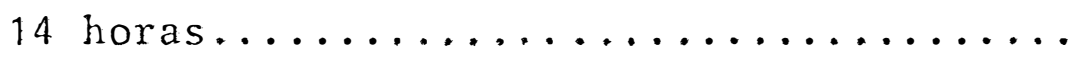


20 Duração média do período pupal de machos e fêmeas de $D$. saccharalis, criada em dietas artificiais, incluindo 6 genótipos de feijão. Temperatura: $25 \pm 10 \mathrm{C}$; UR: $70 \pm 10 \%$ foto

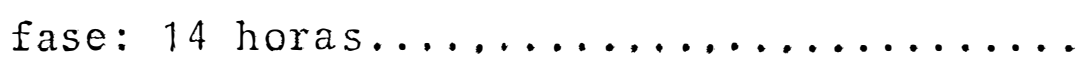

21 Efeito fagoestimulante. ("pegamento in cial") e viabilidade das diferentes fases de desenvolvimento de $D$. saccharalis criada em dietas artificiais incluindo 6 genótipos de feijão e um híbrido de milho. Tem peratura: $25 \pm 10 \mathrm{C}$; UR: $70 \pm 10 \%$ fotofase: 14

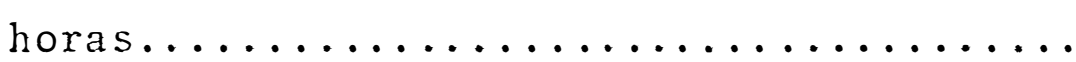

22 Porcentagem de adultos deformados de $D$. saccharalis obtios de lagartas mantidas em dietas artificiais incluindo 6 genótipos de feijão e um hỉbrido de milho. Temperatura: $25 \pm 10 \mathrm{C}$; UR: $70 \pm 10 \%$; fotofase: 14 horas...

23 Duração média do período larval de machos e fêmeas de $D$. saccharalis criadosem dietas artificiais incluindo fontes protéicas variāveis (germe de trigo, soja, levedura, c $\underline{a}$ 
seína, feijão e farelo de trigol e porcentual de contaminação por fungos. Temperatu ra: $25 \pm 10^{\circ} \mathrm{C}$; UR: $70 \pm 10 \%$; fotofase: 14 horas

24 Peso médio de pupas (machos e fêmeas) de 0 . saccharalis criada em dietas artificiais incluindo fontes protéicas variāveis (germe de trigo, soja, levedura, caseína, feijão e farelo de soja). Temperatura: $25 \pm 10 \dot{C} ; \quad$ UR: $70 \pm 10 \%$; fotofase: 14 horas...........

25 Duração média do período pupal de machos e fêmeas de $D$. saccharalis criada em dietas artificiais incluindo fontes protëicas variảveis (germe de trigo, soja, levedura, caseína, feijão e farelo de trigo). Temperatura: $25 \pm 1{ }^{\circ} \mathrm{C}$; UR: $70 \pm 10 \%$ fotofase: 14

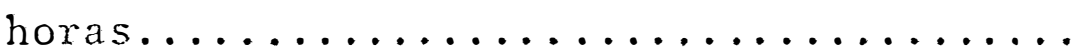

26 Efeito fagoestimulante ("pegamento inicial") e viabilidades das diferentes fases do desenvolvimento de $P$. saccharalis criada em dietas artificiais incluindo fontes pro tẻicas variäveis (germe de trigo, soja, Ie 
TABELA

vedura, rnsuína, feijão e farelo de trigo). Temperatura: $25 \pm 1{ }^{\circ} \mathrm{C}$; UR: $70 \pm 10 \%$; fotofase:

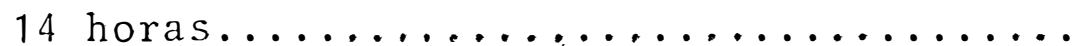

27 Porcentagem de adultos deformados de $D$. saccharalis obtidos de lagartas mantidas em dietas artificiais incluindo fontes protêicas variâveis (germe de trigo, soja, 1e vedura, caseína, feijão e farelo de soja). Temperatura: $25 \pm 10 \mathrm{C}$; UR: $70 \pm 10 \%$; fotofase:

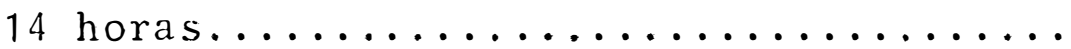

28 Duração média do período larval de machos e fêmeas de $D$. saccharalis criada em dietas artificiais incluindo 6 genótipos de soja e uma com milho. 'Nutrimaiz' e porcentual de contaminação por fungos. Temperatú ra: $25 \pm 10 \mathrm{OC}$; UR: $70 \pm 10 \%$; fotofase: 14 horas

29 Peso médio de: pupas (machos e fêmeas) de 0 . saccharalis criada em dietas artifi ciais incluindo 6 genótipos de soja e uma de milho 'Nutrimaiz'. Temperatura: $25 \pm 1{ }^{\circ} \mathrm{C}$; UR: $70 \pm 10 \%$; fotofase: 14 horas......... 
Duração mêdia do período pupal de machos e fêmeas de $D$. saccharalis criada em dietas artificiais incluindo 2 genótipos de soja e uma de milho 'Nutrimaiz'. Temperatura : $25 \pm 1{ }^{\circ} \mathrm{C}$; UR: $70 \pm 10 \%$; fotofase: 14 horas...

31 Efeito fagoestimulante ("pegamento inicial") e viabilidades das diferentes fases do desenvolvimento de $D$. saccharalis criada em dietas artificiais incluindo 6 genōtipos de soja e'uma de milho. 'Nutrimaiz'. Temperatu ra: $25 \pm 1{ }^{\circ} \mathrm{C}$; UR: $70 \pm 10 \%$; fotofase: 14 horas

32 Porcentagem de adultos deformados de $D$. saccharalis obtidos de lagartas mantidas em dietas artificiais incluindo 6 genót pos de soja e uma de milho. 'Nutrimaiz'. Tem peratura: $25 \pm 10 \mathrm{C}$; UR: $70 \pm 10 \%$ fotofase: 14

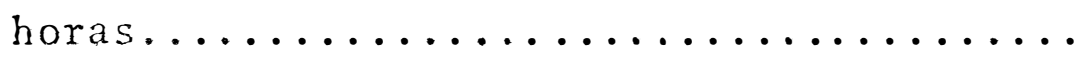

33 Duração média do período larval de D. saccharalis criada em dietas artificiais incluindo 5 genótipos de milho e porcentual de contaminação por fungos. Temperatura: $25 \pm 1{ }^{\circ} \mathrm{C}$; UR: $70 \pm 10 \%$; fotofase: 14 horas... 
34 Peso médio de pupas (machos e fêmeas)

de $D$. saccharalis criada em dietas artifi ciais incluindo 5 genótipos de milho. Temperatura: $25 \pm 10 \mathrm{C}$; UR: $70 \pm 10 \%$ fotofase: 14

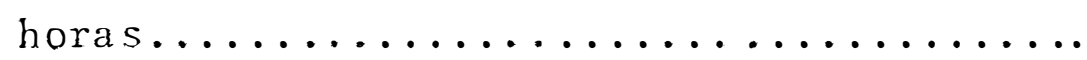

35 Duração média do período pupal de machos e fêmeas de $D$. saccharalis obtidos de lagartas criadas em dietas artificiais incluindo 5 genótipos de milho. Temperatura: $25 \pm$ $10 \mathrm{C}$; UR: $70 \pm 10 \%$; fotofase: 14 horas......

36 Porcentagem de adultos deformados de $D$. saccharalis criada em dietas artificiais incluindo 5 genōtipos de milho. Temperatura: $25 \pm 1{ }^{\circ} \mathrm{C}$; UR: $70 \pm 10 \%$; fotofase: 14 horas

37 Efeito fagoestimulante ("pegamento inicial") e viabilidades das diferentes fa ses do desenvolvimento de $D$. saccharalis cria da em dietas artificiais incluindo 5 genótipos de milho. Temperatura: $25 \pm 10^{\circ} \mathrm{C}$; UR:

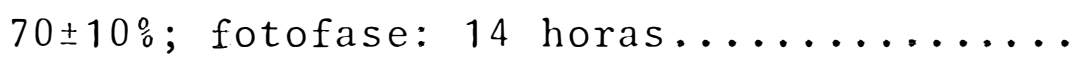


38 Duração média e viabilidade do período la $\underline{r}$ val de $D$. saccharalis criada em 4 dietas artificiais e porcentual de contaminação por fungos. Temperatura: $25 \pm 1{ }^{\circ} \mathrm{C} ; \mathrm{UR}: 70 \pm 10 \%$ fo-

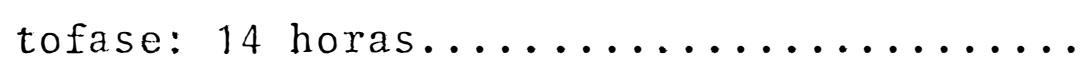

39 Largura média da cảpsula cefảlica, razão de crescimento e duração de cada ínstar de 10 lagartas de $D$. saccharalis criadas em dieta artificial de HENSLEY e HAMMOND (1968). Tem peratura: $25 \pm 10 \mathrm{C}$; UR: $70 \pm 10 \%$; fotofase: 14

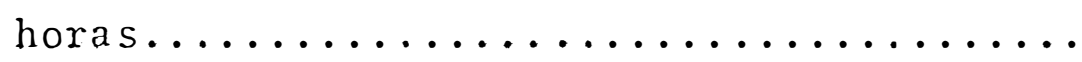

40 Largura mêdia da cápsula cefálica, razão de crescimento e duração de cada ínstar de 10 lagartas de $D$. saccharalis criadas em dieta artificial utilizada na Usina Santa Bärbara. Temperatura: $25 \pm 10 \mathrm{C}$; UR: $70 \pm 10 \%$ fo-

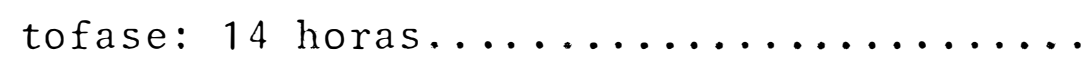

41 Largura média da cāpsula cefālica, razão de crescimento e duração de cada ínstar de 10 lagartas de 0 . saccharalis criadas em dieta de feijão. 'Carioca', germe de trigo e levedura (E). Temperatura: $25 \pm 1{ }^{\circ} \mathrm{C}$; UR: $70 \pm$ $10 \%$; fotofase: 14 horas............. 
42 Largura média da câpsula cefálica, razão de crescimento e duração de cada ínstar de 10 lagartas de 0 . saccharalis criadas em dieta artificial incluindo milho 'Nutrimaiz', germe de trigo e levedura. Temperatura:25 $1{ }^{\circ} \mathrm{C}$; UR: $70 \pm 10 \%$; fotofase: 14 horas......

43 Porcentagem de lagartas de 0 . saccharalis que apresentaram 5 ou 6 instares, criadas em 4 dietas artificiais. Temperatura: $25 \pm$ $1{ }^{\circ} \mathrm{C}$; UR: $70 \pm 10 \%$; fotofase: 14 horas.....

44 Peso médio das pupas (machos e fêmeas) de 0 . saccharalis criada em 4 die tas artificiais. Temperatura: $25 \pm 1{ }^{\circ} \mathrm{C}$; UR:

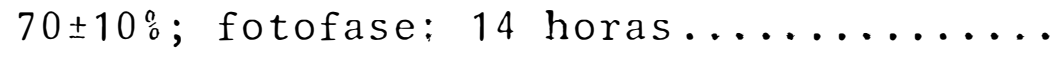

45 Duração média e viabilidade do período pu pal de machos e fêmeas de $D$. saccharalis criada em 4 dietas artificiais. Temperatu ra: $25 \pm 10 \mathrm{C}$; UR: $70 \pm 10 \%$; fotofase: 14 ho-

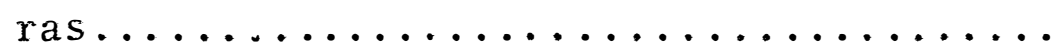


46 Longevidade média de machos e fêmeas e por centagem de adultos deformados de $D$. isaccharalis criada em 4 dietas artificiais. Temperatura: $25 \pm 1^{\circ} \mathrm{C}$; UR: $70 \pm 10 \%$; fotofase:

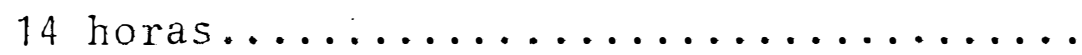

47 Período de prë-oviposição e total de ovos por fêmea de $D$. saccharalis criada em 4 dietas artificiais. Temperatura: $25 \pm 10 \mathrm{C}$; UR: $70 \pm 10 \%$; fotofase: 14 horas..........

Período de incubasão e viabilidade dos ovos de $D$. saccharalis criada em 4 dietas artificiais. Temperatura: $25 \pm 1{ }^{\circ} \mathrm{C}$; UR: $70 \pm$

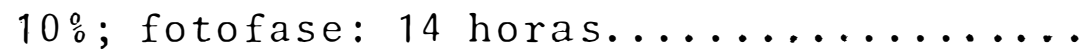

49 Efeito fagoestimulante ("pegamento inicial") e viabilidade total de $D$. saccharalis criada em 4 dietas artificiais. Temperatura: $25 \pm 1{ }^{\circ} \mathrm{C}$; UR: $70 \pm 10 \%$; fotofase: 14 horas

50 Tabela de vida de fertilidade para $D$. saccharalis mantida em dieta artificial à base de feijão 'Carioca', germe de trigo e le- 
vedura. Temperatura: $25 \pm 1{ }^{\circ} \mathrm{C}$; UR: $70 \pm 10 \%$; fo

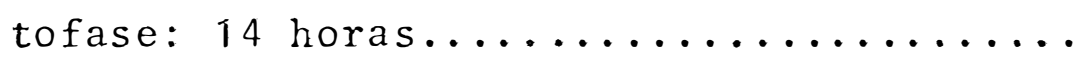

51 Tabela de vida de fertilidade para 0 . saccharalis mantida em dieta artificial de mi 1ho 'Nutrimaiz', germe de trigo e levedu ra. Temperatura: $25 \pm 1^{\circ} \mathrm{C}$; UR: $70 \pm 10 \%$; foto-

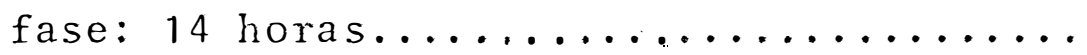

52 Tabela de vida de fertilidade para $D$. saccharalis mantida em dieta artificial de HENSLEY e HAMMOND (1968). Temperatura: $25 \pm$ 10C; UR: $70 \pm 10 \%$; fotofase: 14 horas......

53 Tabela de vida de fertilidade para $D$. saccharalis mantida em dieta artificial da Usina Santa Bárbara. Temperatura: $25 \pm 1{ }^{\circ} \mathrm{C}$; UR: $70 \pm 10 \%$; fotofase: 14 horas..........

54 Alimento consumido (AC), ganho de peso (GP), fezes produzidas (F), digestibilidade apro ximada $(A D)$, eficiências de conversão do $\underline{\text { a }}$ limento ingerido (ECI) e digerido (ECD) de lagartas de $D$. saccharalis, no máximo desen 
TABELA

volvimento, criadas em 4 dietas artificiais. Temperatura: $25 \pm 1^{\circ} \mathrm{C}$; UR: $70 \pm 10 \%$ fo

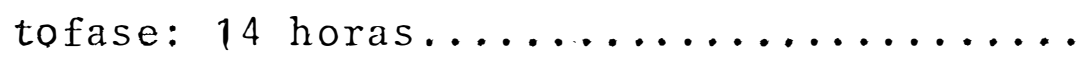

55 Porcentagens de proteína total em lagartas de $D$, saccharalis, no máximo desenvolvimen to, e das 4 dietas utilizadas para a sua criação. Temperatura: $25 \pm 10 \mathrm{C}$; UR: $70 \pm 10 \%$;

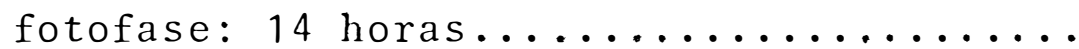

56 Taxa de eficiência,protéica (PER) de laga $\underline{x}$ tas, de $D$. saccharalis, no mäximo desenvol vimento, criadas em 4 dietas artificiais. Temperatura: $25 \pm 1{ }^{\circ} \mathrm{C}$; UR: $70 \pm 10 \%$ fotofase :

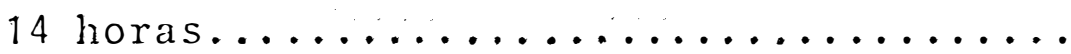

57 Composição e custo de $1000 \mathrm{~g}$ da dieta de HENSLEY E HAMMOND $(1968) \ldots \ldots \ldots \ldots \ldots \ldots$

58 Composição e custo de 1000 g da dieta utilizada na Usina Santa Bärbara..........

59 Composição e custo de $1000 \mathrm{~g}$ da dieta com milho. 'Nutrimaiz' $\ldots \ldots \ldots \ldots \ldots \ldots \ldots$ 
.xxii.

TABELA

Pāgina

60

Composição e custo de 1000 g da dieta com feijão 'Carioca', germe de trigo e levedu-

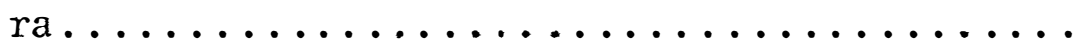

61 Custo da dieta (ORTNi) para a produção de 10.000 lagartas de 0 . saccharalis em 4 meios arti ficiais. Temperatura: $25 \pm 10^{\circ}$; UR: $70 \pm 10 \%$ fo

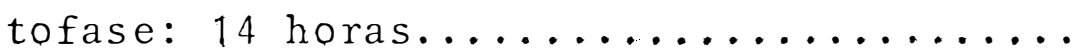




\section{LISTA DE FIGURAS}

FI GURA

Pāgina

1 Grade de arame utilizada para suporte dos tubos de vidro contendo dietas artifi -

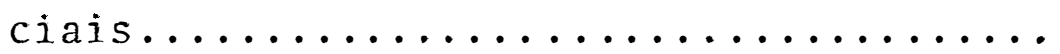

2A Esquema da estante de madeira utilizada pa ra o acondicionamento de tubos de vidro contendo dietas artificiais...........

2B Croqui da estante de madeira utilizada pa ra o acondicionamento de tubos de vidro contendo dietas artificiais...........

3 Posturas e viabilidades diärias de 0 . sac charalis criada em 4 meios artificiais. Temperatura: $25 \pm 10 \mathrm{C} ; \mathrm{UR}: 70 \pm 10 \%$ f fot of ase :

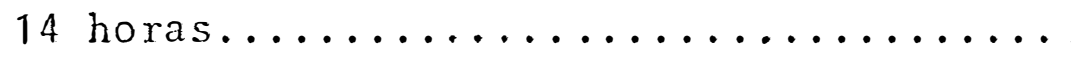

4 Perfil eletroforētico das 4 dietas seleciona-

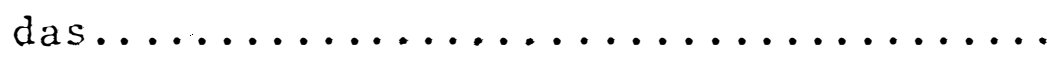


Fenograma obtido da anālise de agrupamento de 4 dietas artificiais, em função dos seus parâmetros biolögicos e nutricionais.. dietas selecionadas, em função dos seus parâmetros biológicos e nutricionais, pe10 método de análise dos componentes prin

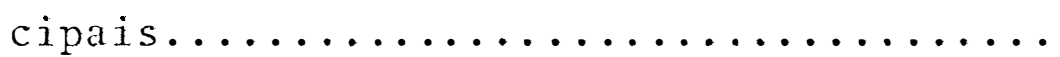




\title{
COMPARAÇ̃̃OO DE DIETAS ARTIFICIAIS PARA A CRIACÃO \\ DE Diatraea saccharalis (FABRICIUS, 1794) \\ (LEPIDOPTERA - PYRALIDAE)
}

\author{
Autor: LAILA HERTA MIHSFELDT \\ Orientador: Dr. JOSE ROBERTO \\ POSTALI PARRA
}

\section{RESUMO}

A presente pesquisa teve por objetivo comparar o desenvolvimento biológico e nutricional de Diatraea sacchara lis (Fabricius, 1794), em diferentes dietas artificiais, tendo como padrão as dietas de HENSLEY e HAMMOND (1968) e a utilizada na Usina Santa Bärbara, município de Santa Bärbara d'0este, SP. Procurou-se desenvolver ou adaptar um meio que fosse compa tível com a realidade brasileira, principalmente em termos de preço e facilidade de aquisição dos componentes.

A pesquisa foi realizada nos laboratórios do Departamento de Entomologia da ESALQ, a $25 \pm 1 \mathrm{OC}^{\circ}$; UR: $70 \pm 10 \%$ e fotofase: 14 horas e dividida em diferentes etapas, variando-se as fontes protéicas utj.lizadas para a preparação das dietas. Deste modo, na 1 a t tapa utilizaram-se, como fontes pro 
têicas, genótipos de feijão e um híbrido de milho; na zạ etapa estas fontes protéicas variáveis foram o germe de trigo, case na, soja, levedura, feijão e farelo de trigo; genótipos de soja e milho 'Nutrimaiz' foram as variáveis da 3a etapa, sendo que na 4 a fase, a fonte protéica constituiu-se de genótipos de milho. Selecionaram-se, assim, 2 dietas e realizou-se uma 5 a $\underline{\text { e }}$ tapa procurando compará-1as às dietas tomadas como padrão, através da avaliação de diferentes parâmetros biológicos, nutr $\underline{i}$ cionais e custo de produção.

As dietas selecionadas foram as que incluíam fei jão 'Carioca', germe de trigo e levedura e aquela com milho 'Nutrimaiz' que também incluía germe de trigo e levedura. A dieta com milho 'Nutrimaiz' apresentou-se como sendo a mais adequada para a criação da broca-da-cana pelos seguintes motivos: as fêmeas tiveram maior capacidade de postura; baixa contaminação por microrganismos; os insetos apresentaram uma alta viabilidade total, taxa líquida de reprodução elevada e alta eficiência de conversão de alimento. Os insetos mantidos neste meio apresentaram também uma elevada capacidade de conversão protéica, embora o nerfil eletroforético tenha revelado um menor número de bandas protéicas em relação à dieta de HEN $\underline{S}$ LEY e HAMMOND (1968). Uma análise global, realizada através da análise de agrupamento, revelou que a dieta com milho 'Nutrimaiz' foi a que se destacou para criação de $D$. saccharalis, den tre: as quatro dietas testadas. 
Devido a adequação biológica e nutricional da dieta de milho 'Nutrimaiz', ao seu baixo custo, facilidade de preparo e aquisição de seus componentes recomenda-se a sua utịlização para a criação da broca-da-cana, em condições de 1aboratório. 
.xxviii.

\author{
COMPARISON OF ARTIFICIAL DIETS FOR REARING \\ OF Diatraea saccharalis (FABRICIUS, 1794) \\ (LEPIDOPTERA: PYRALIDAE)
}

Author: LAILA HERTA MIHSFELDT

Adviser: Dr. JOSE ROBERTO POSTALI PARPA

\title{
SUMMARY
}

This research aimed to compare the biological and nutritional development of Diatraea saccharalis (Fabricius, 1794) on different artificial diets, considering as standard diets that described by HENSIEYY e HAMOND (1968) and the one used by the "Usina Santa Bärbara", Santa Bārbara d'0este, Sp. It was tried to develop or adapt a medium which would be compatible with the Brazilian conditions, mainly in terms of price and easiness for purchasing ingredients. The experimental phase, carried out in the laboratories of the Department of Entomology, "Escola Superior de Agricultura Luiz de Queiroz", at the temperature of $25 \pm 10 \mathrm{C}$, relative humidity $70 \pm 10 \%$ and 14 -hour photophase, was divided into different stages, by varying the protein sources utilized in the preparation of the diets. So, in the $1 \mathrm{st}$ stage, bean genotypes and a hybrid corn were used as protein sources; in the 2 nd stage these variable protein sources were wheat germ, casein, soybean, yeast, bean and 
heat bran; soybean genotypes as well as. 'Nutrimaiz' corn were the variables in the 3rd stage, and corn genotypes were the protein source in the 4 th stage. Tyn diets were selected and a 5 th stage was held in order to compare them to the standard diets, by analysing different biological and nutritional parameters and production costs. The diets selected were those which included 'Carioca' bean, wheat germ and yeast, and that with 'Nutrimaiz' corn, which also included wheat germ and yeast. The 'Nutrimaiz' corn diet arose as the most suitable for rearing the sugarcane borer because of the following: the females had greater oviposition capacity; low contamination by microorganisms was observed; the insects showed high total viability, high net reproduction and high efficiency of conversion of food. The insects that were mantained on that medium also showed a high protein conversion capacity, though the electrophoretic profile revealed smaller number of protein bands as compared to the HENSLEY \& HAMMOND (1968) diet. The overall analysis, made by means of cluster analysis, revealed that the 'Nutrimaiz' corn diet surpassed the others for laboratory rearing of $D$. saccharalis from the 4 diets utilized. Due to the biological and nutritional suitability of the 'Nutrimaiz' corn diet, to its low cost, ready preparation and easy component purchasing, it is suggested that it be utilized for sugarcane borer rearing, under laboratory conditions. 


\section{INTRODUCÃOO}

A manutenção de grandes colônias de insetos fitófagos em laboratório tem-se mostrado primordial para o suces so de programas de Manejo de Pragas (KOGAN, 1980). Assim, visando facilitar ao suprimento contínuo de insetos durante todo o ano, independente da presença da planta hospedeira, houve, nas $\bar{u} 1$ timas décadas, um grande avanço nas pesquisas com meios artificiais, com o objetivo de substituir os meios naturais. A compilação bibliográfica realizada por SINGH (1977), incluindo cerca de 1850 citações de meios artificiais para insetos de di ferentes ordens e famílias, è um eloqüente atestado deste avan ço.

Atualmente, a manutenção de colônias de insetos através de meios artificiais, é uma atividade rotineira em laboratórios ligados às pesquisas entomológicas (básicas ou apli 
cadas), especialmente em países desenvolvidos.

No Brasil, embora não exista tradição na ärea de dietas artificiais, desde 1969 (GALLO et alii, 1969) vem sendo utilizado um meio sintético para a criação ue Diatraea saccharalis (Fabricius, 1794) e produção de seus parasitóides, dentro do Programa deControle Bio lógico da Broca-da-Cana, desenvolvido pelo IAA-PLANALSUCAR - Programa Nacional de Melhoramento da Cana-de-Açúcar, COPERSUCAR - Cooperativa dos Pro dutores de Açúcar e Âlcool do Estado de São Paulo, Universidades e Usinas particulares. Este primeio meio utilizado foi o de HENSLEY e HAMMOND (1968) que, por ser um meio nutricionalmente completo, é até hoje, a base de muitas dietas usadas para a criação de $D$. saccharalis. Muito enbora promova um bom desenvolvimento da broca-da-cana é um meio cujos componentes são cạ ros e de difícil aquisição, especialmente em centros urbanos menos desenvolvidos.

Assim, a presente pesquisa teve por objetivo comparar o desenvolvimento biológico e nutricional de $D$. saccharalis em diferentes dietas artificiais em relação à dieta de HENSLEY e HAMMOND (1968) e a uma dela derivada, tomadas como padrao, procurando desenvolver ou adaptar uma dieta que fos se compatível com a realidade brasileira, especialmente em ter mos de preços de componentes e de facilidade de aquisição dos mesmos, e que proporcionasse, evidentemente, um bom crescimento de $D$. saccharalis. 


\section{REV ISÃO DE LITERATURA}

PAN e LONG (1961) desenvolveram uma criação mas sal de Diatraea saccharalis (Fabricius, 1794) em dieta artificial composta de pó de plantas de milho, sacarose, coíesterol, sais de Wesson, extrato de levedura, āgar e āgua e em meio natural constituído de "ponta" de cana. Quando mediram o consumo alimentar do inseto, os autores não verificaram diferenças significativas entre os dois meios de criação, observan do, porém, que as fêmeas pareciam ser mais sensíveis às defi ciências nutricionais em ambos os substratos.

WONGSIRI e RANDOLPH (1962) compararam a biolo gıa da broca-da-cana à $25^{\circ} \mathrm{C}$, em meio artificial composto de germe de trigo, caseina, sacarose, sais de Wesson, cloreto de colina, ágar, alginato de sódio, ácido ascórbico e āgua, e em meio natural constituído de colmos de sorgo. Observaram a ocor 
rência de 5 instares larvais em ambos os substratos, com a duração da fase larval menor em meio natural. O período pupal foi maior em dieta artificial, sendo que o ciclo total foi de 42,8 e 40 dias, respectivamente, nos meios artificial e natural.

Uma criação massal de $D$. saccharalis foi conduzida por SANTA CRUZ et alii (1964) visando a obtenção de insetos para estudos de resistência de variedades de milho à broca-da-cana. Com a finalidade de desenvolver uma dieta mais adequada para a criação do inseto, os autores compararam quatro dietas e observaram que, por três gerações sucessivas, as dietas à base de soja e milho opaco foram superiores àquelas preparadas com feijão cozido ou cru, levando-se em consideração a viabilidade pupal, peso médio de pupas, longevidade de adul tos e nümero de ovos por fêmea..

MISKIMEN (1965) estudou os efeitos da temperatu ra e umidade relativa do ar no desenvolvimento da broca-da-cana e verificou que a melhor temperatura para a criação do inse to foi a de $26^{\circ} \mathrm{C}$, pois, nesta temperatura foram registradas as maiores viabilidades das fases imaturas e as menores porcenta gens de anormalidades de adultos. Segundo o autor, o primeiro e segundo instares exigem umidades inferiores à $85 \%$, pois $\underline{u}$ midades mais elevadàs podem provocar a condensação de água nas paredes dos tubos de criação e causar a morte das lagartas; a partir do terceiro instar a umidade pode chegar a $90 \%$ sem afe- 
tar o normal desenvolvimento do inseto. A dieta utilizada pelo autor era composta de "pontas". de cana-de-açūcar, ảgua, ảgar, metil p-hidroxibenzoato, ācido sōrbico, formaldeído e äcido as cörbico.

WALKER et alii (1966) pesquisando técnicas de criação para $D$. saccharalis, utilizaram duas dietas: uma com fibra de milho, pó de cenoura, ảgar, levedura de cerveja, caseína, benzoato de sódio, metil p-hidroxibenzoato, äcido ascór bico, ācido hidroclorídrico $1 \mathrm{~N}$ e ägua; na outra, ao invēs de àgua, era utilizado um filtrado de milho. Os autores compararam estas dietas com a proposta por MISKIMEN (1965) e com a dieta natural, constituída de pedaços de colmo de milho e conseguiram, nas duas dietas pescuisadas, una viabilidade total de $90 \%$, em condições de pequenas produções diärias.

BOWLING (1967) relatou que, em uma dieta consti tuída de feijão, levedura de cerveja, ācido ascórbico, metil p-hidroxibenzoato, ảcido sórbico, formaldeído, āgar e āgua, o período médio exigido para o desenvolvimento larval e pupal de D. saccharalis era de 38 dias, sendo o peso médio das pupas de $95 \mathrm{mg}$; foi observada uma oviposição média de 268 ovos/fêmea com um perído de incubação de 6,5 dias.

Estudos da biologia de $D$. saccharalis foram con duzidos por WALKER (1968), visando a aplicação da técnica do inseto estéril. Para verificar o melhor estāgio de desenvolvimento do inseto para realizar a esterilização com raios $\gamma{ }^{60} \mathrm{Co}$, 
o autor observou que a broca desenvolveu-se melhor em dieta ar tificial (milho, cenoura em nó e caseína) do que em dieta natu ral (colmos de milho).

HENSLEY e HAMMOND (1968) apresentaram uma técn ca para a criação de $D$. saccharalis em laboratório, utilizando uma dieta artificial nutricionalmente completa e que apresenta va os seguintes componentes: sais de Wesson, caseina, sacarose, germe de trigo, cloreto de colina, solução vitamínica, áci do ascórbico, formaldeído, metil p-hidroxibenzoato, aureomici na, água e ágar. Os autores constataram que esta dieta com fon te protéica à base de germe de trigo e caseína era favorável ao desenvolvimento larval de 0 . saccharalis, desde que as pupas obtidas eram comparáveis, em vigor e tamanho, às obtidas em campo, sobre milho ou cana-de-açúcar. O ciclo de ovo a pupa durou, em mêdia, 32 dias e a viabilidade total variou de $64 \%$ nos meses de verão a $84 \%$ nos meses de inverno.

o desenvolvimento biolögico de $D$. saccharalis foi pesquisado por VAN DINTHER e GOOSSENS (1970), em nove dietas artificiais que continham diferentes quantidades de feijão, milho, cenoura e arroz. Os insetos foram mantidos em labo ratório em temperaturas variáveis de 24 a $28^{\circ} \mathrm{C}$, umidades relativas de 65 a $90 \%$ e fotofase de 12 horas. A melhor dieta testa da pelos autores foi a que continha os seguintes componentes: feijão, pó de plantas de milho, pó de cenoura, levedura de cer veja, ácido ascórbico, ágar, metil p-hidroxibenzoato, sulfato de estreptomicina, penicilina, ácido sórbico e água; os inse- 
tos nela criados apresentaram alta viabilidade larval (81\%), $\underline{\text { e }}$ levado peso de pupas (machos e fêmeas), maior fertilidade das fêmeas (média de 394 ov́os) e alta viabilidade dos ovos (94\%), em comparação às demais. Nesta dieta, os autores observaram um período larval de 32 dias, período pupal de 8 dias e um período de incubação de 6 dias.

No Brasil, os trabalhos com dietas artificiais foram iniciados no Departamento de Entomologia da ESALQ, em Pí racicaba, SP, por GALLO et alii (1969). Estes autores utilizaram a dieta proposta por HENSLEY e HAMMOND (1968) para a mult $\underline{\mathbf{i}}$ plicação de $D$. saccharalis, em um programa visando ao seu controle biológico, atravës de taquinídeos. A partir daí, outros trabalhos de pesquisa foram desenvolvidos, visando a criação desse inseto no país. Deste modo, SGRILLO (1973) estudou a cria ção do inseto, em condições de laboratório, com a finalidade de automatizar a distribuição da dieta e dos ovos, melhorar as técnicas de manipulação dos insetos e analisar os custos da criação.

SANFORD (1971) comparou 3 dietas artificiais para a criação da broca-da-cana e concluiu que a dieta à base de fei jão era melhor do que a dieta de Adkinsson, modificadapor HENSLEY e HAMMOND (1968), e, esta por sua vez, era superior à dieta CSM composta de farinha de milho, farinha de soja, leite em pó desengordurado, vitaminas, sais minerais, germe de trigo, àcido ascórbico, formaldeído, metil p-hidroxibenzoato, àcido sórbico, āgua e àgar. 
MENDONCGA FILHO (1973) descreveu detalhadamente as operações que se processam em laboratório para a multiplica ção dos taquinídeos parasitóides da broca-da-cana-de-açúcar, $\underline{u}$ tilizando a dieta de HENSLEY e HAMMOND (1968).

RISCO et alii (1973) criando D. saccharalis em uma dieta artificial, que incluía pó de fibra de cana e pó de cenoura, obtiveram uma porcentagem de $54,12 \%$ de lagartas do 4 ? instar, aptas a serem "inoculadas" com parasitóides da broca.

KING et alii (1975) estudaram técnicas de criação da broca-da-cana em laboratório, utilizando a dieta de HENS LEY e HAMMOND (1968) e observaram que as melhores temperaturas para a criação foram as de $26^{\circ} \mathrm{C}$ para ovos e pupas, $28^{\circ} \mathrm{C}$ para as lagartas e $24^{\circ} \mathrm{C}$ para os adultos, com umidade relativa de $85^{\circ}$ e fotofase de 14 horas.

VILLACORTA e MAGRO (1975) descreveram uma metodologia de criação de $D$. saccharalis, em laboratório, com dieta à base de feijão. Testando diferentes variedades de feijão, como fonte de proteína, NOVARETTI e TERAN (1976) verificaram que na dieta com feijão branco ocorreu uma maior poncentagem de brocas aptas para a "inoculação" com parasitöides do inseto e as pupas eram mais pesadas.

MORAES e GALLO (1976) desenvolveram um aparelho para a distribuição de dieta em tubos de criação de $D$. saccharalis, em que conseguiram uma redução de $85 \%$ sobre o tempo gasto com métodos convencionais.

WALDER et alii (1976) pesquisaram e obtiveram 
uma dieta artificial de baixo custo e não suscetível à contami nação por microrganismos, para a criação da broca-da-cana, com posta de feijão, levedura de cerveja, ácido ascórbico, metil phidroxibenzoato, ágar, germe de trigo, aureomicina, bagacilho de cana, sacarose, cloreto de colina, formaldeído, solução vitaminica, ảcido acético glacial e ảgua.

SGRILLO et alii (1976) desenvolveram uma dieta artificial com feijão. 'Jalo', mais barata do que as dietas até então utilizadas no Brasil. A criação da broca-da-cana foi fei ta em salas climatizadas reguladas a $25^{\circ} \mathrm{C}$ e $75 \%$ de UR e, nestas condições, os autores obtiveram uma postura média de 350 o vos por fêmea, com viabilidade de $91 \%$. O período larval foi de, aproximadamente, 30 dias e o pupal de 10 dias. As pupas que originaram fêmeas pesavam, em mêdia, $100 \mathrm{mg}$ e aquelas que deram origem a machos, $63 \mathrm{mg}$.

BREWER (1976) comparou dietas com diferentes fon tes protéicas (feijão, caseína, germe de trigo e soja), discutindo os custos e as qualidades destas dietas para D. sacchara lis. A dieta à base de farinha de soja e germe de trigo propor cionou, segundo o autor, um menor período larval (20,8 dias), baixa mortalidade larval $(4,4 \%)$, pupas mais pesadas (machos: 103,6 mg e fêmeas: 176,8 mg) e baixo custo. O mesmo autor, em 1977a, observou que pantotenato de cálcio, niacina e riboflavi na são essenciais para o crescimento, desenvolvimento e reprodução da broca-da-cana .

Lagartas de $D$. saccharalis foram criadas por 5 
gerações sucešivas em uma dieta à hase de farinha de soja e germe de trigo e esterilizada com luz germicida, por BREWER (1977b). O autor observou que as lagartas apresentavam um período de desenvolvimento menor e davam origem a pupas (fêmeas) mais pesadas do que quando criadas na mesma dieta não esterili zada. O mesmo autor, em 1981, comparou duas dietas, uma à base de soja e óleo de milho e outra contendo soja e germe de trigo. As lagartas foram criadas à $29,5^{\circ} \mathrm{C}, 75^{\circ}$ de umidade relativa e fotofase de 14 horas. Verificou que os períodos larval e pupal foram menores nos insetos criados na dieta de soja e óleo de milho, sendo que as nunas foram também, mais pesadas, nas 5 gerações analisadas.

MENDES (1980) descreveu, detalhadamente, a composição e o preparo da dieta utilizada nos. laboratórios do IAAPLANALSUCAR, para a criação de $D$. saccharalis.

TERAN (1980) citou que as dietas adotadas pelo Setor de Entomologia da COPERSUCAR para a criação da broca-da- cana e de seus parasitóides eram, basicamente, derivadas das dietas de feijão, da de HENSLEY e HAMMOND (1968) e de uma desenvolvida nos insetários da COPERSUCAR à base de milho seco e triturado e solução de ácido fosfórico mais ácido propiônico.

BREWER (1981) comparou duas dietas artificiais para $D$. saccharalis através da avaliação de índices de consumo e utilização. O autor observou que o consumo total de alimento (gramas/lagarta) foi maior na dieta à base de farinha de soja e ôleo de milho. As lagartas alimentaram-se mais, ganharam mais 
peso e produziram mais fezes em períodos de 40 e 120 horas quando se alimentaram desta dieta do que na dieta considerada padrão (à base de farinha de soja e germe de trigo).

ROE et alii (1982) criaram D. saccharalis, com sucesso, em 9 dietas artificiais e observaram que o período larval constou de até 7 instares, sendo que $28,3 \%$ das lagartas apresentaram 5 instares; 68,9, 6 instares e 2,8\%, 7 instares. OSORES et alii (1982) descreveram um método de criação da broca-da-cana-de-açúcar em meio artificial constituîdo de feijãobranco, germe de trigo, levedura de cerveja, a gar, ácido ascórbico, ảcido sórbico, metil p-hidroxibenzoato, formaldeỉdo e água, visando a criação massal dos parasitóides do inseto. Os insetos foram mantidos à $26 \pm 2{ }^{\circ} \mathrm{C}$ e apresentaram um ciclo total médio de 45 dias. Nestas condições, segundo os autores, as lagartas com 18 dias estariam aptas para a "inoculac̣ano" com parasitóides.

Segundo SINGH (1983) uma djeta jdeal para a cria ção massal de insetos deve ter as seguintes características: (1) deve fornecer todos os nutrientes para a produção de insetos comparáveis aos da natureza; (2) deve ser de baixo custo; (3) deve ser facilmente preparada; a partir de ingredientes de fácil aquisição no mercado; (4) deve servir, de preferência, para a criação de um grande número de espécies de insetos; (5) poder ser armazenada por Iongos periodos e (6) deve proporcionar uma viabilidade total de, pelo menos, 75\%. Além disso, o autor reteriu que o tamanho e o indice de desenvolvimento do inseto 
devem ser similares àqueles da natureza. Deve, segundo o autor, haver acasalamento e os ovos serem viáveis, com os adultos reproduzindo-se continuamente, sem perder o vigor ou fecun didade. Assim, este autor desenvolveu uma dieta liofilizada, com todas estas caracteristicas, para 41 espécies de insetos, in cluindo 0 . saccharalis.

MACEDO e.t alii (1983) descreveram detalhadamente o fluxograma de criação da broca-da-cana e de seus parasitóides. A dieta utilizada para a criação do hospedeiro é constituída de ảcido ascórbico, açūcar, sais de Wesson, metil p-hi droxibenzoato, germe de trigo, farelo de soja, cloreto de coli na, acromicina, compiexo vitamínico, solução vitamínica, formaldeído e ágar.

MÉLO (1984) estudou a biologia de D. sacchara lis, utilizando a dieta artificial de HENSLEY e HAMMOND (1968), em cinco temperaturas constantes $\left(20,22,25,30\right.$ e $\left.32^{\circ} \mathrm{C}\right)$, visando dar subsídios para a criação massal da praga, em condi ções de laboratório, bem como determinar suas exigências térmi cas. Concluiu que a temperatura ideal para adultos (obtenção de ovos) e a de $20^{\circ} \mathrm{C}$, sendo a de $30^{\circ} \mathrm{C}$ a mais adequada para manutenção de ovos, lagartas e pupas da broca-da-cana. 
.13.

\section{MATERIAL E MÉTODOS}

A pesquisa com Diatraea saccharalis (Fabricius, 1794) foi conduzida nos laboratórios, de Biologia do Departamento de Entomologia da Escola Superior de Agricultura "Luiz de Queiroz", Universidade de São Paulo, Piracicaba, SP, à tempera tura de $25 \pm 10 \mathrm{C}$, umidade relativa de $70 \pm 10 \%$ e fotofase de 14 ho ras.

3.1. ComparacÃo DE PARÂMETROS BIOLÓgICOS DE D. saccharalis EM DIFERENTES DIETAS ARTIFICIAIS

A presente pesquisa foi conduzida em diferentes etapas, sendo comparadas dietas com fontes protéicas variáveis, 
à base de feijão, soja, milho, germe e farelo de trigo, levedu ra e caseína com duas dietas tomadas como padrão, quais sejam, as dietas de HENSLEY e HAMMOND (1968) (Tabela 1) e uma modificação desta áieta utizizada no laboratório de Entomologia da $\underline{U}$ sina Santa Bárbara, no município de Santa Bárbara d'Oeste, SP (Tabela 2).

Tabela 1 - Composição da dieta de HENSLEY e HAMMOND (1968).

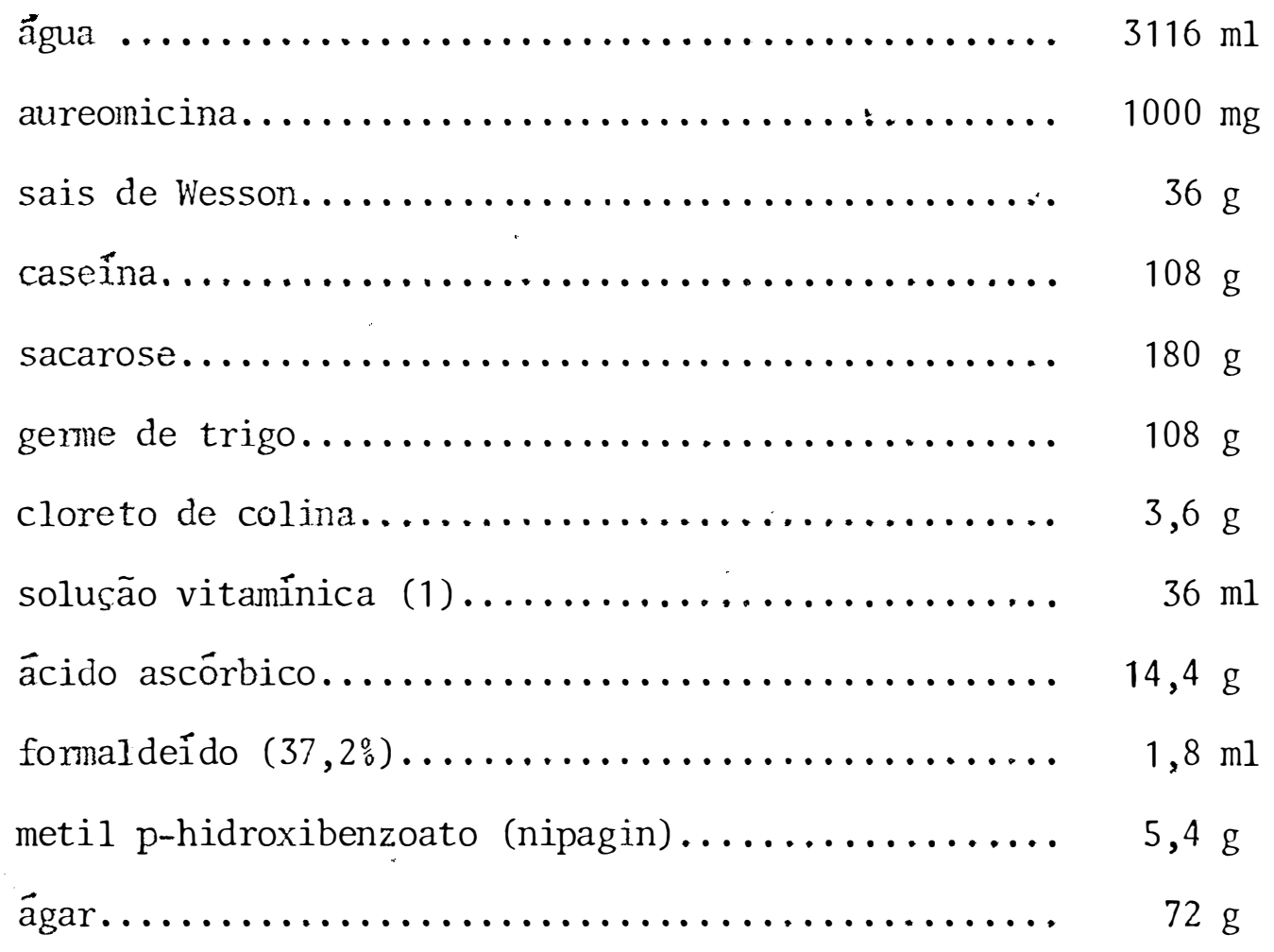

(1) composição da mistura vitamínica (PARRA, 1979): niacinamida: 1,0 g; pan totenato de cálcio: $1,0 \mathrm{~g}$; tiamina: $0,5 \mathrm{~g}$; piridoxina: $0,25 \mathrm{~g}$; ácido fó 1ico: 0,10 g; biotina: $0,02 \mathrm{~g}$; vitamina $B_{12}(1000 \mathrm{mg} / \mathrm{cc}): 2,0 \mathrm{ml}$.

Estes componentes foram diluídos em $1000 \mathrm{ml}$ de âa gua destilada e agitados para perfeita homogeneização. 
Tabela 2 - Composição da dieta utilizada nos laboratórios da Usina Santa Bárbara, em Santa Bárbara d'Oeste, SP.

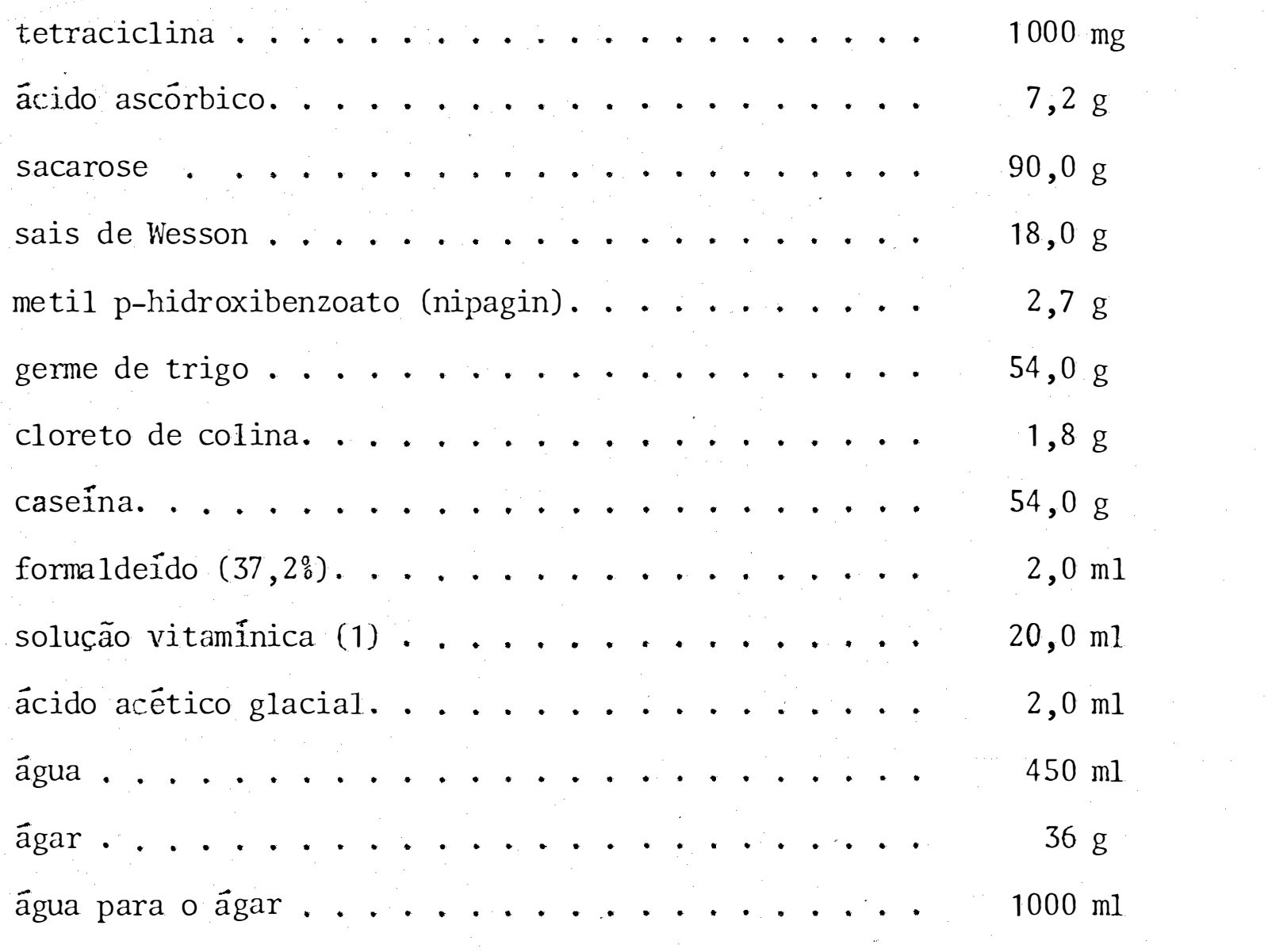

(1.) igual àquela apresentada na Tabela 1.

Os insetos foram obtidos da criação de $D$. saccharalis do laboratório de Entomologia da Usina Santa Bárbara, em Santa Bärbara d'Oeste, SP, exceto na 1 a etapa (item 3.1.) em que foram trazidos do laboratório de Entomologia do PLANALSU $\mathrm{CAR}$, Araras, SP.

Em todas as etapas as dietas foram preparadas 
de acordo com a metodologia descrita por PARRA (1979). Os meios foram então, transferidos para tubos de vidro $(8,5 \mathrm{~cm}$ de comprimento $\times 2,3 \mathrm{~cm}$ de diámetrol tamponados com algodão hidrófobo. Estes tubos tamponados foram nreviamente esterilizados em estufa (à $150^{\circ} \mathrm{C}$ pelo tempo mínimo de 60 minutos).

Cada tubo recebeu uma quantidade de dieta que possibilitasse a complementação da fase larval. Após 24 horas, suficientes para o resfriamento do meio, os tubos foram coloca dos em grades de arame de $25,7 \mathrm{~cm}$ de comprimento $\times 16,2 \mathrm{~cm}$ de largura $\times 7,6 \mathrm{~cm}$ de altura (Figura 1) e levados à uma câmara asséptica modelo PLANALSUCAR (MENDES, 1980), por 60 minutos, para nova esterilização externa. Nesta câmara, fez-se a transferência ("inoculação") de uma lagarta recém-eclodida para cada tubo, com o auxilio de um pincel fino. Estas lagartas foram obtidas da seguinte forma: massas de ovos, colocados em pa pel sulfite, recebidas dos laboratórios mencionados, eram este rilizadas com solução de formaldeîdo a $5 \%$ por 5 minutos e, pos teriormente, lavadas em água destilada por mais 5 minutos, sen do a seguir colocadas para secar. Recortavam-se, então, pedaços do papel sulfite contendo massas de ovos, mantendo-os no fundo de placas de Petri $(10 \mathrm{~cm}$ de diâmetro $x 1,8 \mathrm{~cm}$ de altú ra) revestidos internamente com papel de filtro umedecido. Estas placas eram fechadas com tampas de igual diâmetro, através de fita adesiva, sendo então transferidas para câmara climatizada modelo $095 \mathrm{E}$ da FANEM, regulada a $25 \pm 1^{\circ} \mathrm{C}$, umidade relativa de $75 \pm 10 \%$ e fotofase de 14 horas (condições mantidas no de- 


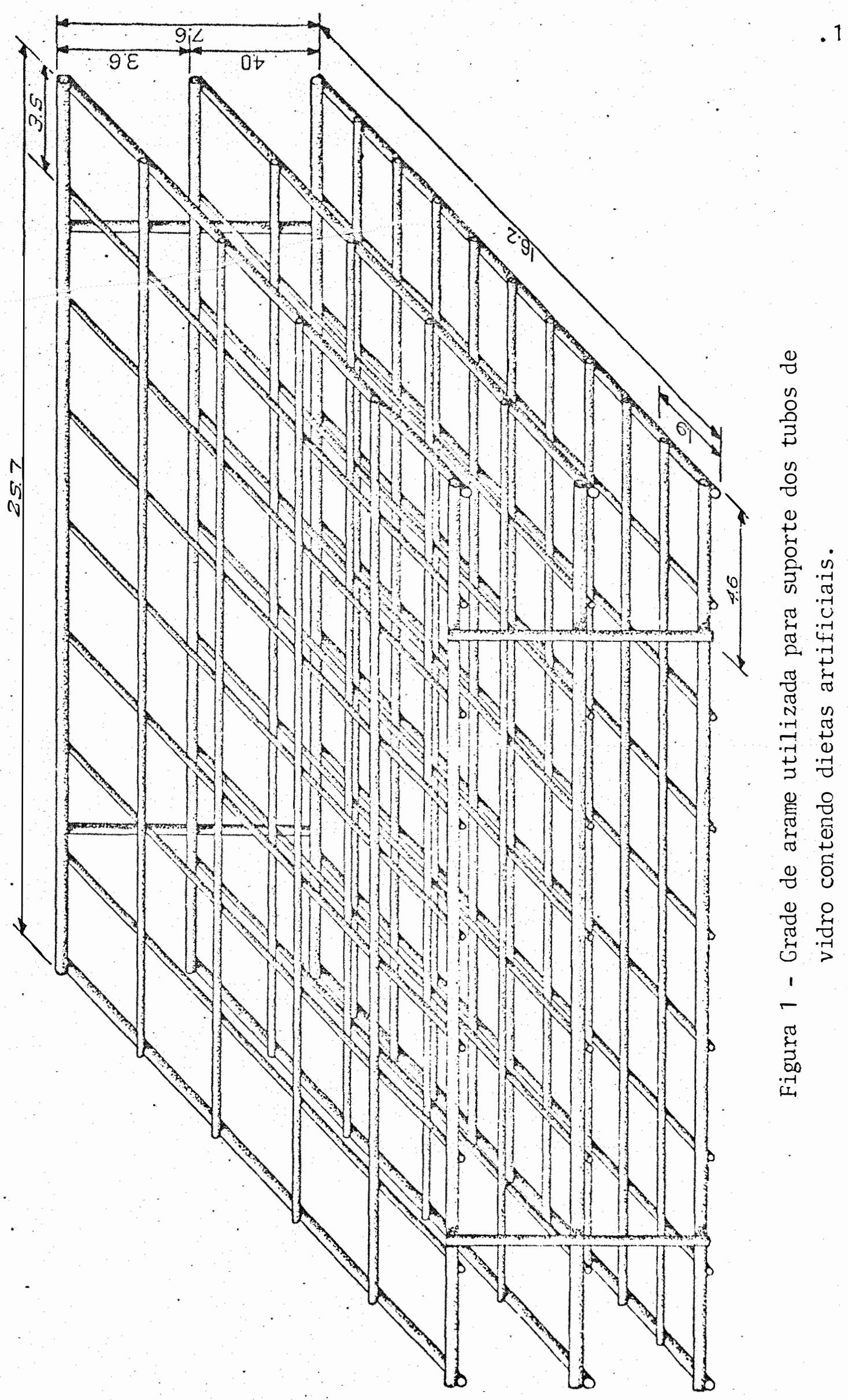


senvolvimento da pesquisa), até a eclosão das lagartas. Após a "inoculação" das lagartas, os tubos eram acondicionados em estantes de madeira (Figs. 2A e B) para que fose completado o desenvolvimento larval. Após a transformação em pupas, estas eram retiradas dos tubos contendo dieta e transfe ridas para outros vazios semelhantes aos utilizados para a criação de lagartas, os quais eram tamponados com algodão hidrófoìo e devidamente identificados. Com 24 horas de idade, as pupas foram pesadas em balança analítica SAUTER, modelo K 1200, separando-as por sexo (BUTT e CANTU, 1962). Observou-se a emergência dos adultos, para a determinação do período pupal.

Os parâmetros biológicos avaliados em cada die ta e em todas as etapas foram as seguintes:

- efeito fagoestimulante da dieta ("pegamento inicial");

- duração e viabilidade da fase larval;

- duração e viabilj.dade da fase pupal;

- peso das pupas com 24 horas de idade;

- porcentagem de adultos com deformações nas asas;

- porcentagem de contaminação por fungos. 


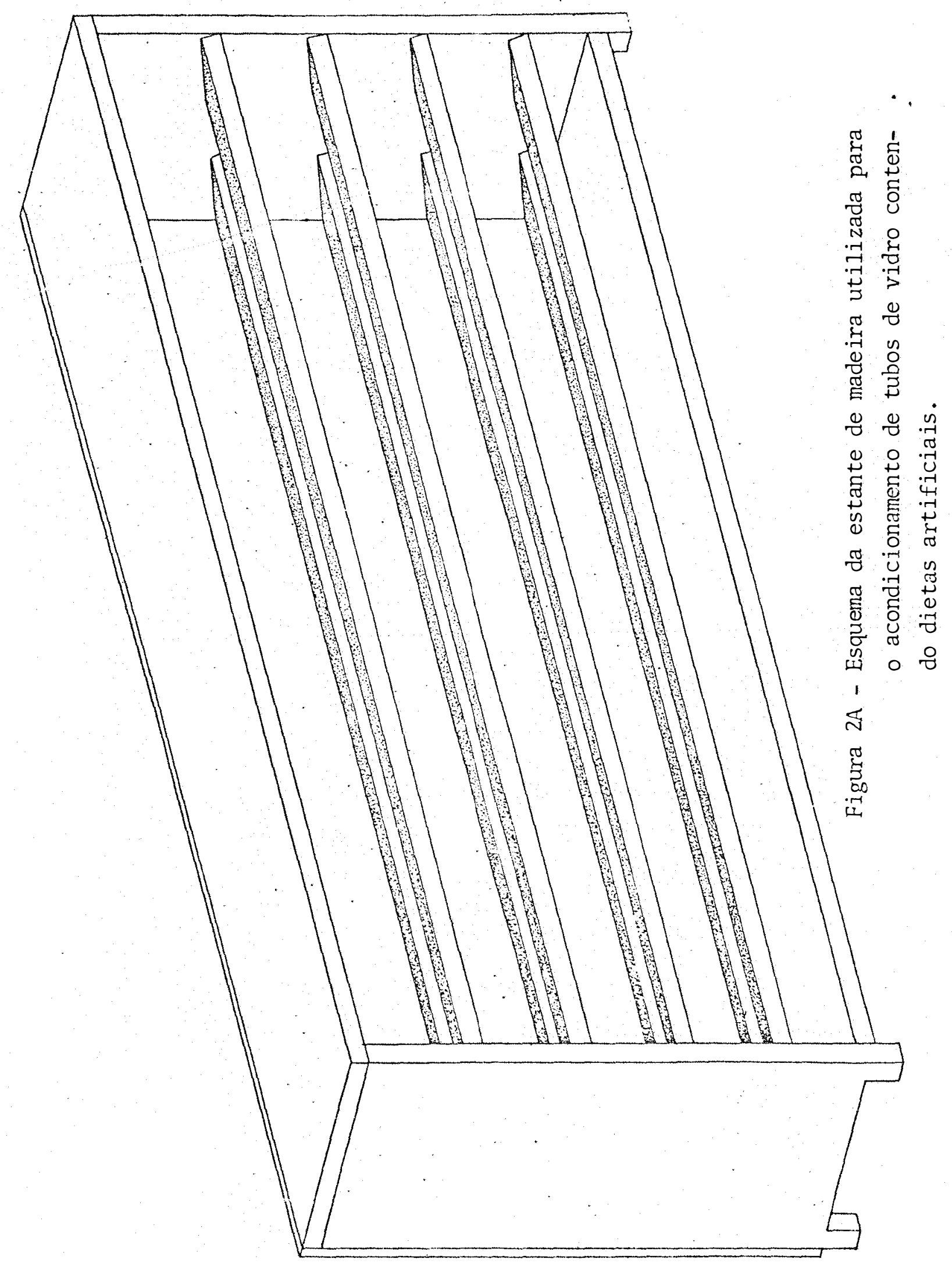




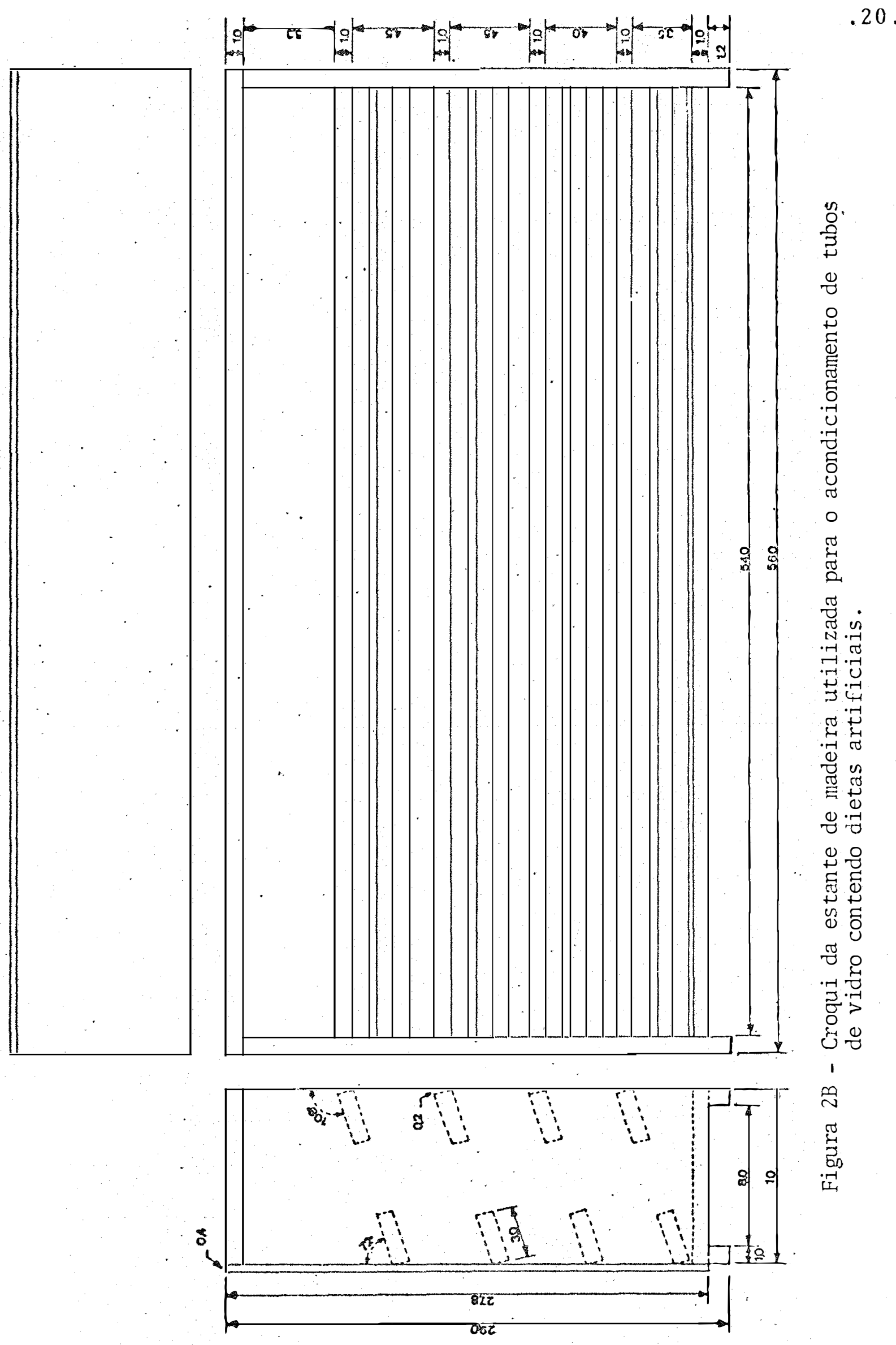




\title{
3.1.1. 1a ETAPA - Fontes Protéicas Variáveis: feijão e milho
}

\begin{abstract}
Nesta etapa, utilizou-se como dieta básica a de KASTEN et alii (1978) (modificação da dieta de BOWLING, 1967) (Tabela 3 ), adotando-se o mesmo procedimento descrito no item 3.1 .
\end{abstract}

Tabela 3 - Composição da dieta de KASTEN et alii (1978j.

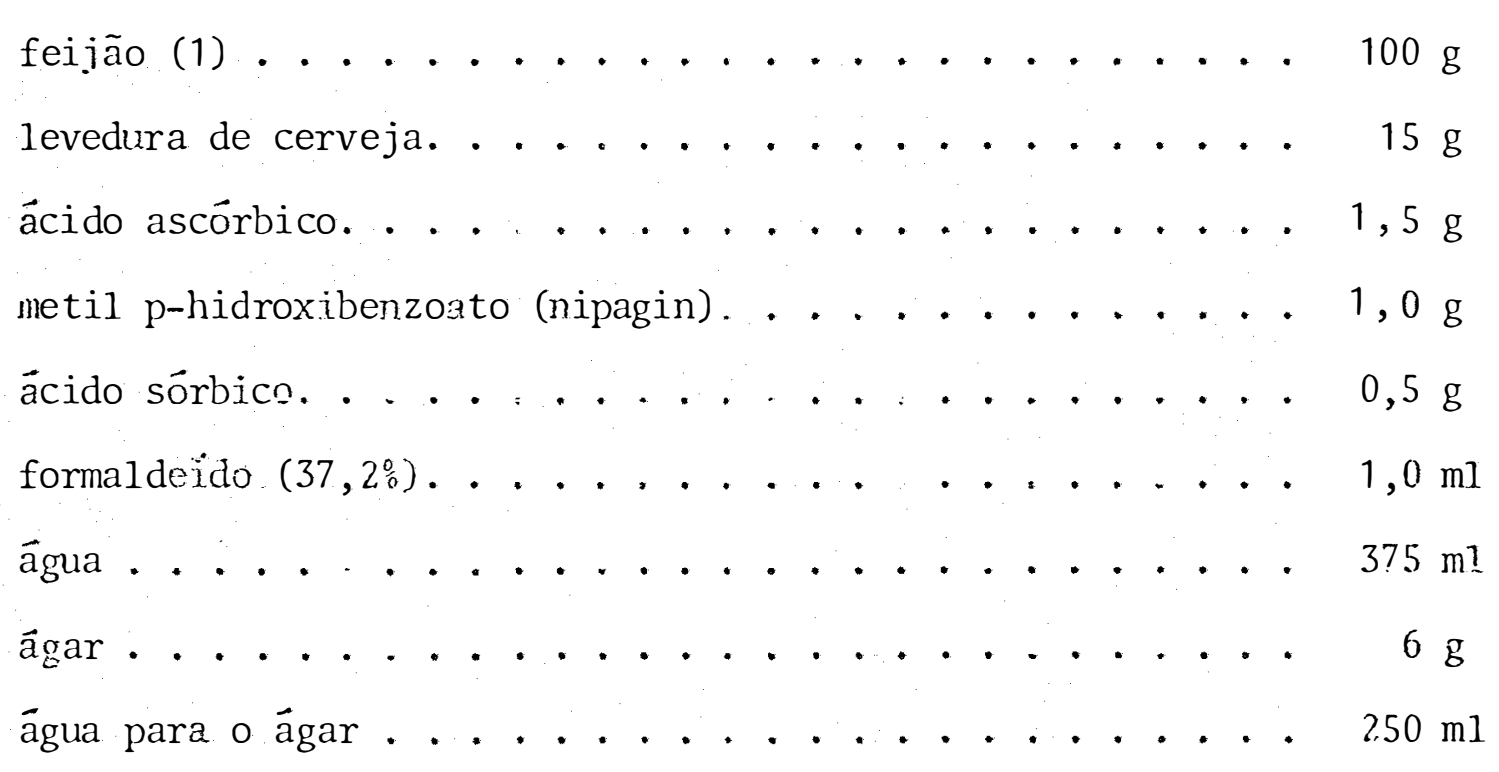

(1) o feijão foi pesado cru e, posteriormente, cozido.

O feijão foi uma das variáveis desta etapa, sendo testadas as variedades Aeté, Aroana, Carioca, Catu, Goiano Precoce e Ro sinha $G_{3}$, num total de 6 dietas. Incluiu-se, tambén, uma dieta contendo milho híbrido moído, cuja composição é apresentada na Tabela 4: 
Tabela 4 - Composição da dieta à base de milho híbrido moído e levedura.

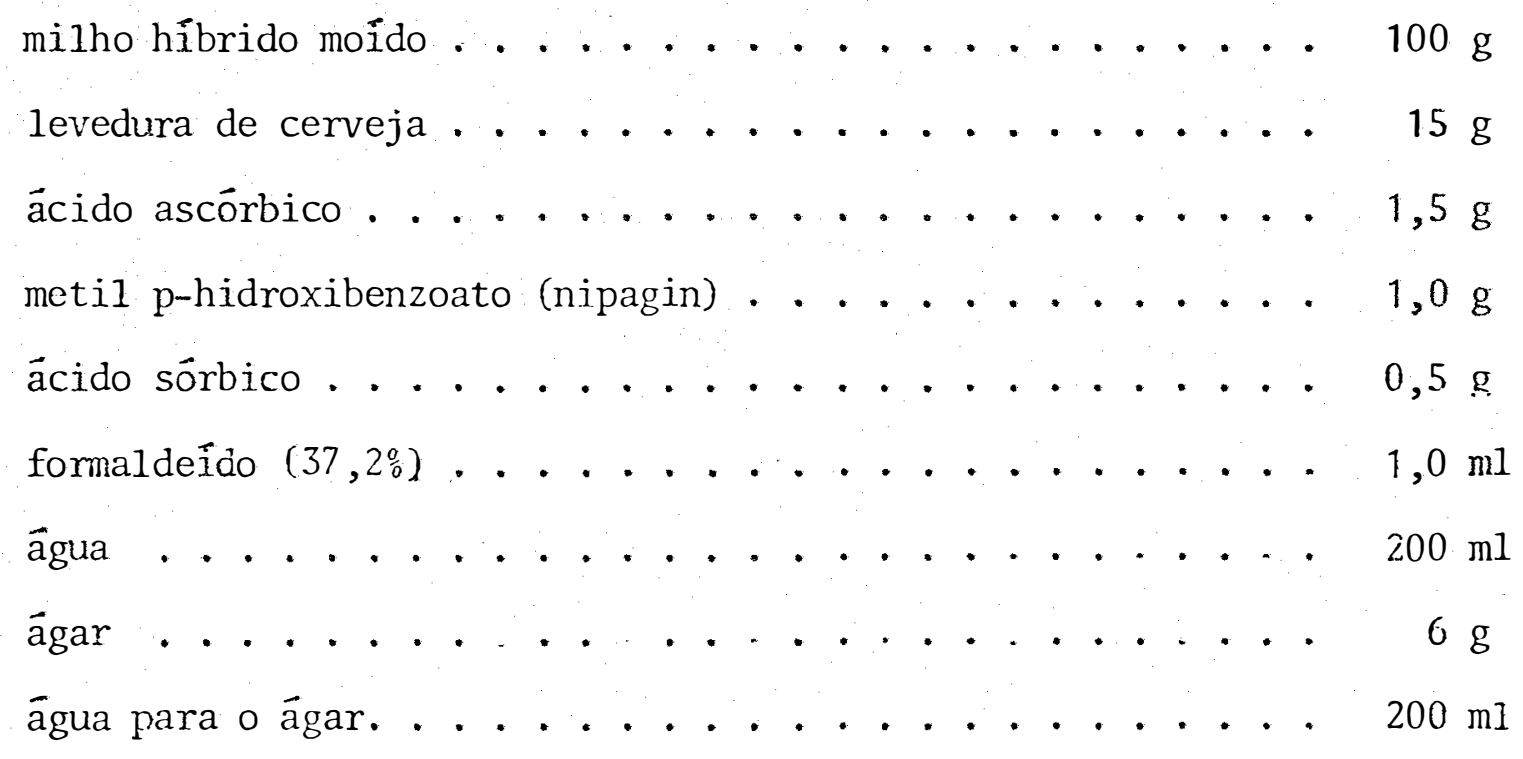

Tanto para as dietas à base de feijão como naquela tendo o milho como variável, a experimentação foi inicia da com 99 lagartas por tratamento.

3:1.2. 2a ETAPA - Fontes Protéicas Variâveis (germe de trigo, soja, levedura, caseína, feijão, farelo de trigo)

Nesta etapa, diversas fontes protéicas foram utilizadas para o preparo das dietas, adotando-se o mesmo proce dimento do item 3.1 . 
As composições das dietas são apresentadas nas Tabelas de 5 a 12 .

Tabela 5 - Composição da dieta à base de farinha de soja e germe de trigo (Dieta A).

germe de trigo . . . . . . . . . . . . . . . 32 g farinha de soja (1) . . . . . . . . . . . 37 g sacarose ........................... 32 g sais de Wesson . . . . . . . . . . . . . . 9 g tetraciclina ............................. $125 \mathrm{mg}$

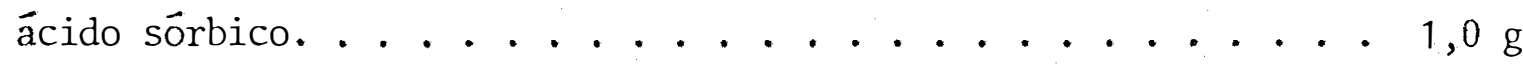
celulose (2) ............................. 4,7 metil p-ridroxibenzoato (nipagin). . . . . . . . 1,6g solução vitamínica (3) . . . . . . . . . . . . . . . 9,0 ml

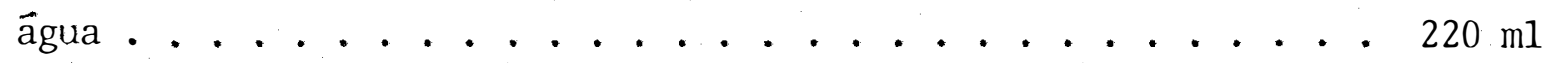

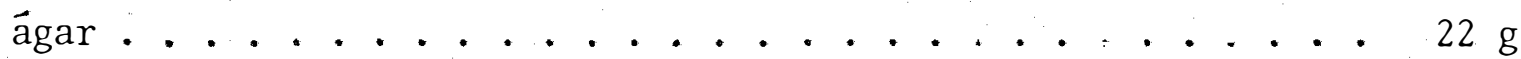

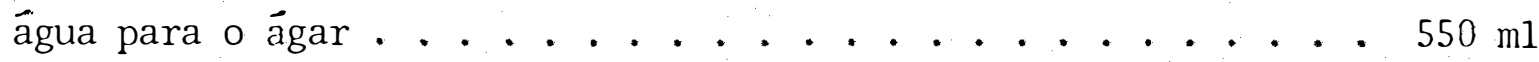

(1) utilizou-se como Earinha de soja o produto Sojinha, da Superbom ${ }^{\circledR}$.

(2) lâminas de celulose de Eucalyptus sp., sulfato branqueadas e trituradas em liquificador.

(3) igual àquela apresentada na Tabela 1. 
Tabela 6 - Composição da dieta à base de germe de trigo e farinha de soja (BERCER, 1963) (Dieta B).

geme de trigo ............... . . 27 g

farinha de soja (1)................... $32 \mathrm{~g}$

sacarose ......................... $32 \mathrm{~g}$

sais de Wesson ................. $9 \mathrm{~g}$

tetraciclina ..................... $125 \mathrm{mg}$

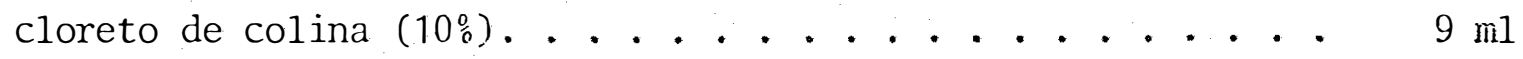

solução vitamínica (2) . . . . . . . . . . . 1,5 ml

ăcido ascórbico. . . . . . . . . . . . . 3,6 m

celulose (3) .................... 4, 4 g

formaldeido $(10 \%) \ldots \ldots . \ldots 3,3 \mathrm{~g}$

metil p-hidroxibenzoato (nipagin). ......... $9 \mathrm{~g}$

$\mathrm{KOH}(4 \mathrm{M}) \ldots \ldots \ldots \ldots \ldots \ldots, \ldots \ldots \ldots$

ägua ........................... $220 \mathrm{ml}$

ägar ......................... $22,5 \mathrm{~g}$

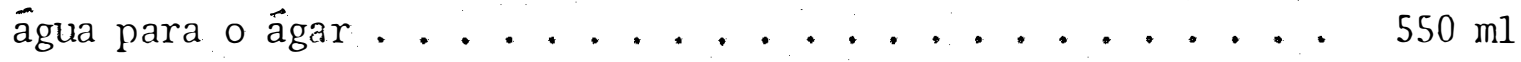

(1) utilizou-se como farinha de soja o produto Sojinha, da Superbom $\left.{ }^{(}\right)$.

(2) igual àquela utilizada na Tabela 1.

(3) igual àquela utilizada na Tabela 5. 
Tabela 7 - Coimposição da dieta à base de germe do trígo c levedura (Dieta C) .

germe de trigo .............. . . $40 \mathrm{~g}$ ácido ascórbico. . . . . . . . . . . . . $26 \mathrm{~g}$ levedura de cerveja........................ 25,5 g metil p-hidroxibenzoato (nipagin). ........... 1,6 g äcido sörbico......................... $0,8 \mathrm{~g}$ formaldeído $(37,2 \%) \ldots \ldots \ldots . \ldots . \ldots 0,65 \mathrm{ml}$ água .............................. $260 \mathrm{ml}$ ägar ............................ àgua para o ägar . . . . . . . . . . . . . 251 g 
Tabela 8 - Composição da dieta à base de germe de trigo e caseína (USDA, 1976) (Dieta D).

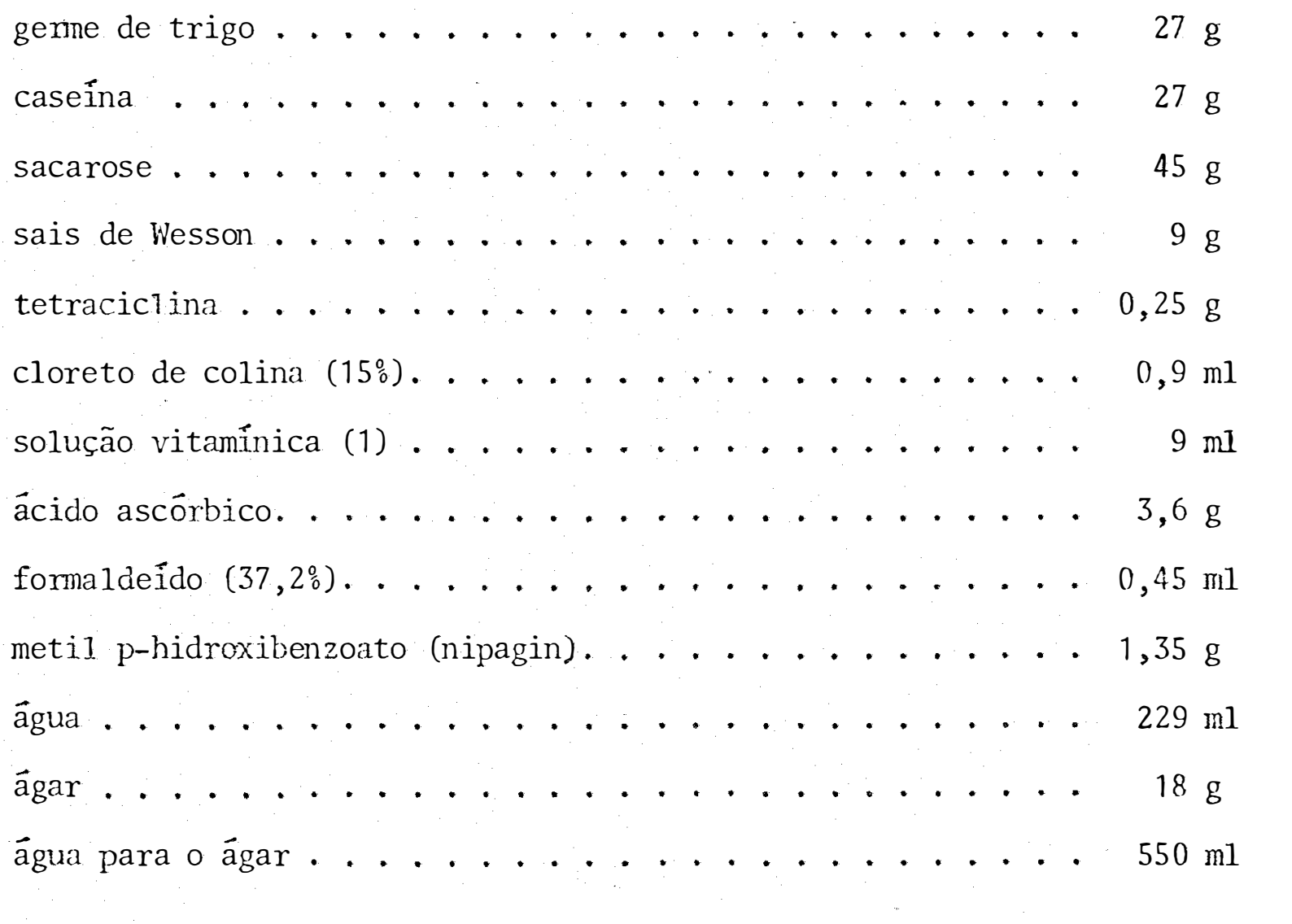

(1) igual àquela apresentada na Tabela 1. 
Tabela 9 - Composição da dieta à base de feijão 'Carioca', germe de trigo e levedura (USDA, 1976) (Dieta E).

germe de trigo .................. $40 \mathrm{~g}$ feijão 'Carioca' ............... 173 g âcido ascôrbico. ................... 2,6 g levedura de cerveja.................... 25,5 g metil p-hidroxibenzoato (nipagin). ........ 1,6 g ácido sórbico. ...................... 0,8g formaldeîdo $\left(37,2^{\circ}\right) \ldots \ldots \ldots \ldots, \ldots \ldots \mathrm{m} 1$

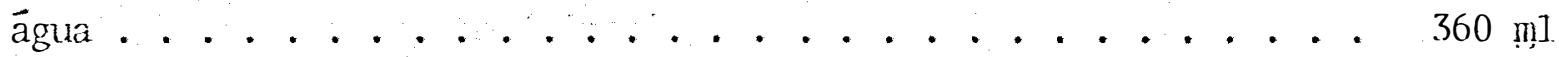

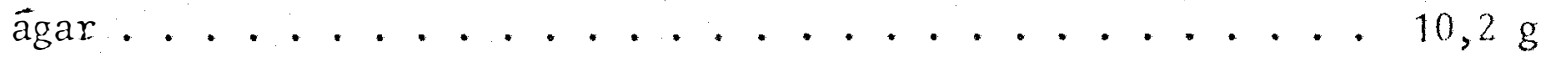
água para o ăgar. . . . . . . . . . . . $251 \mathrm{~m}$. 
Tabela 10 - Composição da dieta de MANGAT (1970) (Dieta F).

germe de trigo .................... $24 \mathrm{~g}$ caseîna .................... $28 \mathrm{~g}$ sacarose .................. $28 \mathrm{~g}$ sais de Wesson ............... $8 \mathrm{~g}$ äcido ascörbico. ................. $16 \mathrm{~g}$ metil p-hidroxibenzoato (nipagin). . . . . . 1,6 g $\mathrm{KOH}(4 \mathrm{M}) \ldots \ldots \ldots \ldots \ldots . \ldots \ldots$ etanol $\left(95_{0}^{\circ}\right) \ldots \ldots \ldots \ldots . \ldots . \ldots . \ldots 15 \mathrm{ml}$ solução vitamínica (1) . . . . . . . . . . 26,4 ml ägua ............................... $300 \mathrm{ml}$ ägar...................... $20 \mathrm{~g}$ ägua para o ágar ............... $350 \mathrm{ml}$

(1) igual àquela apresentada na Tabela 1. 
Tabela 11 - Composição da djeta à hase de germe de trigo e farinha de soja (USDA, 1976) (Dieta G).

germe de trigo ............... . . $27 \mathrm{~g}$ farinha de soja (1).................... 60,5 g sacarose ..................... $11 \mathrm{~g}$ sais de Wesson .................. $9 \mathrm{~g}$ tetraciclina ................. $125 \mathrm{mg}$

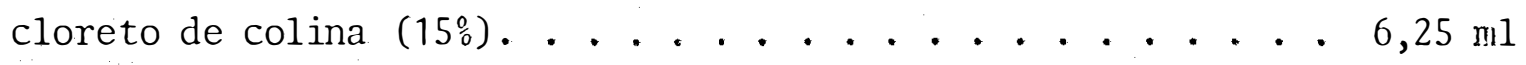

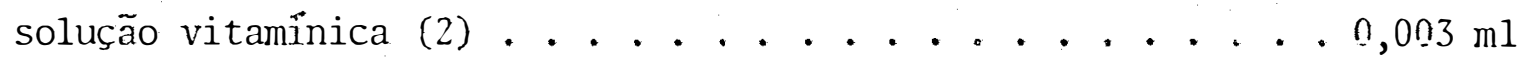

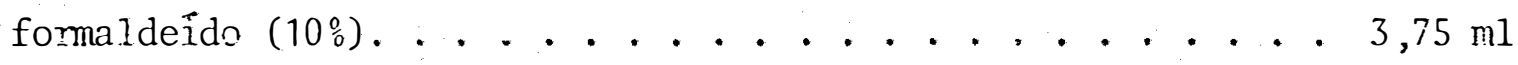
metil p-hidroxibenzoato (nipagin). ........ 1,35 g ácido sörbico. . . . . . . . . . . . . 0,81 g sabugo de milho triturado (3) . . . . . . . 62,5 g $\mathrm{KOH}(4 \mathrm{M}) \ldots \ldots \ldots \ldots . \ldots . \ldots . \ldots 4 \mathrm{ml}$ ácido acético $(25 \%) \ldots \ldots 10 . \ldots 2 . \ldots 1$ ẩgua ............................ $375 \mathrm{ml}$ ágar ............................ àgua para o ágar ............... . . $375 \mathrm{ml}$

(1) utilizou-se como farinha de soja o produto Sojinha, da Superbom ${ }^{\circledR}$.

(2) igual àquela apresentada na Tabela 1.

(3) utilizou-se, em substituição ao sabugo de milho triturado, bagacilho de cana. 
Tabela 12 - Composição da dieta à base de farinha de soja, farelo de trigo e levedura (Dieta $\mathrm{H}$ ).

farinha de soja (1)................... $70 \mathrm{~g}$ farelo de trigo .................. $30 \mathrm{~g}$ levedura de cerveja................. $20 \mathrm{~g}$ ácido ascörbico. . . . . . . . . . . . $20 \mathrm{~g}$ metil p-hidroxibenzoato (nipagin). ........ 1,5 g ácido sórbico. ...................... 0,7g formaldeído $(37,2 \%) \ldots \ldots 20 \mathrm{ml}$ ägua ........................... $200 \mathrm{ml}$ ägar ......................... $7,0 \mathrm{~g}$ ägua para o ägar . . . . . . . . . . . $250 \mathrm{ml}$

(1) utilizou-se como farinha de soja o produto Sojinha, da Superbom ${ }^{\circledR}$.

Em cada uma das dietas foram realizadas observa ções biológicas a partir de 100 lagartas.

\subsubsection{3ạ ETAPA - Fontes Protéicas Variáveis: soja e mitho}

Nesta etapa, utilizaram-se diversos genótipos de soja, em forma de farinha, como fonte protëica para as dietas, sendo os grãos de soja secos e moídos em macromoinho mode lo TE-0340 da TECNAL. A composição da dieta básica utilizada 
nesta etapa é apresentada na Tabela 13.

Tabela 13 - Composição da dieta à base de farinha de soja e levedura.

farinha de soja................... $100 \mathrm{~g}$

levedura de cerveja .............. $15 \mathrm{~g}$

ácido ascōrbico . . . . . . . . . . . . . 1,5 g

metil p-hidroxibenzoato (nipagin) ......... 1,0 g

ácido sórbico . . . . . . . . . . . . . . 0,5 g

formaldeído $\left(37,2^{\circ}\right) \ldots \ldots \ldots \ldots$. . . . . . . . $1,0 \mathrm{ml}$

água ....................... $475 \mathrm{ml}$

ăgar ............................ $6 g$

ägua para o ăgar. ................. $250 \mathrm{ml}$

Foram testados os genótipos IAC2, IAC5, IAC6, IAC7, IAC8, IAC9, IAC773090 e Santa Maria, num total de 8 dietas. Incluiu-se, também, uma dieta à base de milho moído, cuja composição é apresentada na Tabela 14. 
Tabela 14 - Composição da dieta à base de farinha de milho, germe de trigo e levedura (modificação daquela proposta por POITOUT e BUES, 1970).

farinha de milho (1)................... $28 \mathrm{~g}$ levedura de cerveja .............. 7,5 g germe de trigo. ...................... $7,0 \mathrm{~g}$

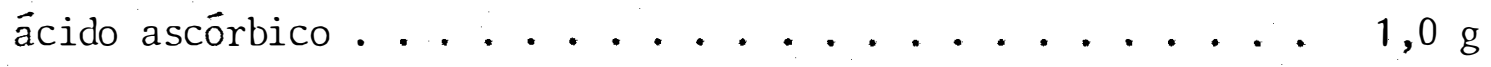
äcido benzóico. . . . . . . . . . . . . 0,25 g metil p-hidroxibenzoato (nipagin) ............ 0,20 g ägua ............................. $100 \mathrm{ml}$

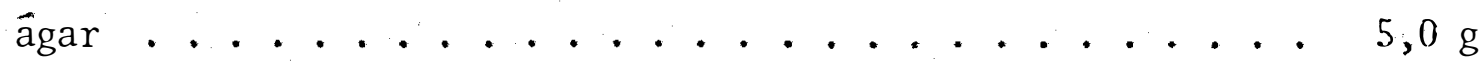
ägua para oägar................. $100 \mathrm{ml}$

(1) utilizou-se o milho do genótipo Nutrimaiz, desenvolvida pela UNICAMP, moído em macromoinho TE-0340 da TECNAL.

Em todas as dietas foram analisadas 75 lagartas.

\subsubsection{4a ETAPA - Fonte Protéica Variável: milho}

Nesta etapa, utilizaram-se 5 genótipos de mi1ho, cujos grãos foram secos e moídos. O genótipo Nutrimaiz(su gary-1 e opaque 2) (milho doce e com baixo teor de amido) foi fornecido pelo Setor de Genétic a da UNICAMP, atravês do Dr. Wil 
liam J. da Silva e os outros 4 genótipos, a saber: VDwx (milho ceroso), VD-2 $\mathrm{br}_{2} \mathrm{O}_{2}$ (milho de norte baixo e opaco), $\mathrm{VD}-2 \mathrm{br}_{2}{ }^{+}$(milho de porte baixo e normal) e $\mathrm{DD}-2$ e $\mathrm{su}_{2} \mathrm{O}_{2} \mathrm{br}_{2}$ (milho doce, opaco e de porte bai xo) foram fornecidas pelo Departamento de Genética da ESALQ, atravês do Dr. Geraldo A. Tosello.

As porcentagens de proteina total e lisina das diferentes variedades de miłho são apresentadas na Tabela 15 .

Tabela 15 - Porcentagens de proteina total e lisina das diferentes varieda des de milho utilizadas nas dietas para criação de $\mathcal{D}$. sacchara lis.

\begin{tabular}{|c|c|c|c|}
\hline Variedades & 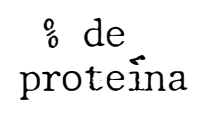 & $\begin{array}{l}\stackrel{\circ}{0} \text { de } \\
\text { lisina }\end{array}$ & Fonte \\
\hline Nutrimaiz & 10,40 & 4,35 & SILVA et alii (1978) \\
\hline VDwX & $\cong 11$ & 2,5 & TOSELLO, G.A., inf. pessoal \\
\hline $\mathrm{VD}-2 \mathrm{br}_{2} \mathrm{O}_{2}$ & $\cong 10$ & 3,5 a 3,8 & TOSELLO, G.A., inf. pessoa] \\
\hline $\mathrm{VD}-2 \mathrm{br}_{2}^{+}$ & $\cong 11$ & 2,5 & TOSELLO, G.A., inf. pessoal \\
\hline$V D-2 s_{2} \mathrm{O}_{2} \mathrm{br}_{2}$ & $\cong 10$ & 4,0 & TOSELLO, G.A., inf. pessoal \\
\hline
\end{tabular}

Nesta etapa, iniciou-se a pesquisa com 75 laga $\underline{r}$ tas por tratamento. 


\subsection{ANÁLise estatística}

Os valores dos diferentes parâmetros biológicos estudados nas 4 etapas foram submetidos à análise de variância, sendo as médias comparadas pelo teste de Tukey, ao nível de $5 \%$ de probabilidade, sen do o delineamento estatístico, em todos os experimentos, inteiramente casualizado.

\subsection{COMPARACÃO DAS 4 DIETAS SELECIONADAS}

Com base na análise estatística e levando-se em consideração as facilidades de aquisição dos componentes e pre paro dos meios, foram selecionadas 2 dietas entre as dietas avaliadas nas 4 etapas, além das duas consideradas como padrão de comparação. Deste modo, avaliaram..se, comparativamente, as dietas constituídas de feijão 'Carioca' (Dieta E) (Tabela 9), e milho 'Nutrimaiz' (Tabela 14), a de HENSLEY e HAMMOND (1968) (Tabela 1) e a dos laboratórios da Usina Santa Bárbara (Tabe1a. 2).

Além dos parâmetros biológicos avaliados anteriormente, foram observados:

- período de pré-.oviposição;

- total de ovos/fêmea;

- viabilidade dos ovos/dia de postura;

- período de incubação;

- longevidade de machos e fêmeas. 
Para a observação destes parâmetros foram separados adultos de 0 . saccharalis recêm-emergidos, na proporção de 2 machos para 1 fémea (MISKIMEN, 1965), em gaiolas feitas de tubos de PVC com $10 \mathrm{~cm}$ de diâmetro e $22 \mathrm{~cm}$ de altura, num total de 10 "conjuntos" para cada uma das 4 dietas. A parte interna das gaiolas foi revestida com papel sulfite (MENDES et alii, 1977; MENDES, 1980); na superfície inferior era colocada uma placa de Petri, de $16 \mathrm{~cm}$ de diâmetro, revestida de papel de filtro para a manutenção da umidade: A extremidade supe rior foi fechada com plástico transparente contendo perfurações que permitiam a ventilação. Tanto o papel sulfite como o papel de filtro eram umedecidos diariamente (MARTINS, 1983).

Os adultos foram alimentados com solução aquosa de mel à $10 \%$, fornecida por capilaridade, através de um pavio de algodão (rolo dental "Johnson's"), mantido dentro de peque nos recipientes de vidro. Este alimento era trocado a cada dois dias (tempo suficiente para que não fermentasse), enquanto que as posturas eram retiradas diariamente.

Das massas de ovos obtidas nas folhas de papel sulfite, recortavam-se pedaços de papel correspondentes a uma alíquota de mais ou menos 100 ovos, para que se pudesse determinar a sua viabilidade e o período de incubação, determinados pela contagem diāria do número de lagartas eclodidas. As massas de ovos foram, previamente, tratadas com solução de formal deído $10 \%$ durante 10 minutos e depois permaneciam em água destilada por mais 10 minutos, para uma esterilização de superfí- 
cie. Essas massas foram, então, transferidas para caixas de ma terial plästico rígido de $6,3 \mathrm{~cm}$ de diâmetro $x 2,3 \mathrm{~cm}$ de altura, forradas com papel de filtro levemente umedecido e vedadas com fita adesiva, para evitar fugas de lagartas recém-eclo didas. As massas de ovos restantes foram acondicionadas em sacos de polietileno devidamente identificados, para a contagem total e mantidas em câmara climatizada modelo 095E da FANEM, regulada a $25 \pm 1^{\circ} \mathrm{C}$, umidade relativa de $70 \pm 10 \%$ e fotofase de 14 horas até a eclosão das lagartas:

A contagem de ovos (aliquota e nümero total) foi feita próxima ao final do estágjo embrionário, quando as . cabeças das lagartas (pontos escuros) já eram distintas, o que facilitava a visualização e aumentava a precisão experimental.

\subsubsection{Nümero de Instares Iarvais}

Para observar se havia alguma interferência da dieta na duração e número de ínstares larvais, retiraram-se de cada uma das 4 dietas selecionadas, 10 lagartas, das quais mediu-se diariamente a largura da câpsula cefälica. As medições foram feitas através de uma ocular graduada OLYMPUS OSM, acoplada a um microscópio-estereoscópico OLYMPUS VMT. 


\subsubsection{Tabela de Vida de Fertilidade}

Com os resultados obtidos nas 4 dietas selecionadas, elaboraram-se as tabelas de vida de fertilidade, sendo que os valores das colunas $x, m x$ e $\ell x$ e os indices Ro, $T, r_{m} e$ $\lambda$ foram calculados segundo SILVEIRA NETO et alii (1976), como descrito a seguir:

\section{$x$ = intervalo de tempo no qual foi tomada a amostra;}

$m x=$ fertilidade específica (número de descendentes produzidos no estágio por fêmea e que darão fêmeas; é, portanto, cal culada em função da razão sexual).

$\ell x=$ taxa de sobrevivência no intervalo de amostragem.

Com base nestes dados, foram calculados os indi ces:

Ro = taxa líquida de reprodução, onde:

$$
\text { Ro }=\sum m x \quad l x ;
$$

$\mathrm{T}$ = duração média de uma geração, onde:

$$
\mathrm{T}=\frac{\sum \mathrm{mx} \cdot \ell \mathrm{x} x}{\operatorname{Ro}}
$$




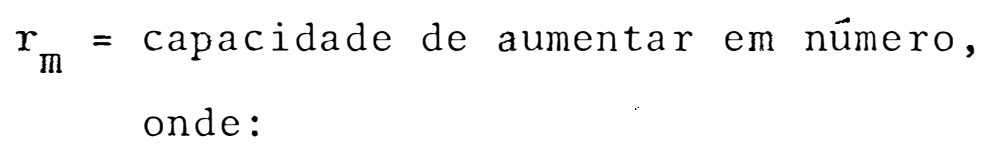
onde:

$$
r_{m}=\frac{R o}{T}
$$

$\lambda=$ razão finita de aumento, onde:

$$
\lambda=e^{r_{m}} \text {. }
$$

3.3.3. Nutrição Quantitativa - Consumo e Utilização do Alimento

Para calcular o consumo e utijização do alimento, foram determinados os indices nutricionais de digestibilidade aproximada (AD) e as eficiências de conversão do alimento ingerido (ECI) e do alimento digerido (ECD), propostos por WALL BAUER (1968), cujas fórmulas são as seguintes:

$$
\begin{aligned}
& \mathrm{AD}=\frac{\mathrm{PI}-\mathrm{PF}}{\mathrm{PI}} \times 100 \\
& \mathrm{ECI}=\frac{\mathrm{GP}}{\mathrm{PI}} \times 100 \\
& \mathrm{ECD}=\frac{\mathrm{GP}}{\mathrm{PI}-\mathrm{PF}} \times 100
\end{aligned}
$$


onde:

PI = peso do alimento consumido durante o período de alimentação;

$P F=$ peso das fezes eliminadas no referido período;

$\mathrm{GP}=$ ganho de peso da lagarta no período experimental.

Assim, para se determinar estes parâmetros foram utilizados 40 tubos para cada uma das 4 dietas seleciona das, iniciando-se com uma lagarta recém-eclodida por recipiente de criação. Quando as lagartas atingiram o máximo desenvolvimento foram mortas em "freezer" e postas a secar em estufa mantida à $55^{\circ} \mathrm{C}$, juntamente com as fezes existentes no tubo, as quais foram cuidadosamente separadas do alimento restante. Após o material ter secado, pesaram-se as fezes e as lagartas, sendo que para se determinar o ganho de peso das lagartas considerou-se o peso inicial desprezível (igual a zero). Além des ses tubos com lagartas, 10 outros foram mantidos sem lagartas e postos a secar, em estufa, para que se pudesse calcular a per da de água do meio. Com este fator de correção pôde-se calcular o peso seco inicial da dieta fornecida às lagartas. A sobra de dieta de cada tubo foi, tambëm, posta a secar, para que se pudesse calcular o peso do alimento ingerido pela lagarta. Portanto, todos os resultados basearam-se em peso de matëria seca.Para a coleta de dados de consumo e utilização de alimento utilizaram-se as planilhas mostradas nas Tabelas 16 e 17 . 
Tabela 16 - Planilha utilizada para anotações dos dados para o cálculo da perda d'água da alíquota.

\begin{tabular}{|c|c|c|c|c|c|}
\hline $\begin{array}{l}\text { Repe- } \\
\text { tições }\end{array}$ & 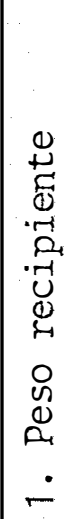 & 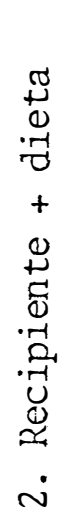 & 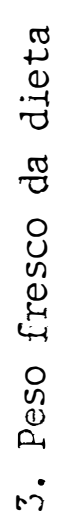 & 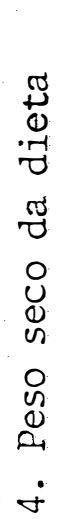 & 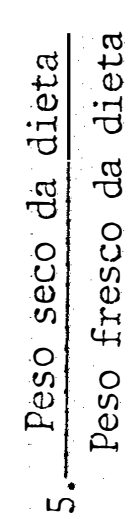 \\
\hline & & & & & \\
\hline & & & & & \\
\hline & & & & & \\
\hline & & & & & \\
\hline & & & & & \\
\hline & & & & & \\
\hline & & & & & \\
\hline & & & & & \\
\hline & & & & & \\
\hline & & & & & \\
\hline & & & & & \\
\hline & & & & & \\
\hline & & & & & \\
\hline & & & & & \\
\hline & & & & & \\
\hline & & & & & \\
\hline & & & & & \\
\hline & & & & & \\
\hline & & & & & \\
\hline & & & & & \\
\hline & & & & & \\
\hline & & & & & \\
\hline & & & & & \\
\hline & & & & & \\
\hline & & & & & \\
\hline & & & & & \\
\hline
\end{tabular}


Tabela 17 - Planilha utilizada para anotações dos dados de consumo e utili zação de alimento por $D$. saccharalis.

\begin{tabular}{|c|c|c|c|c|c|c|c|c|c|}
\hline & 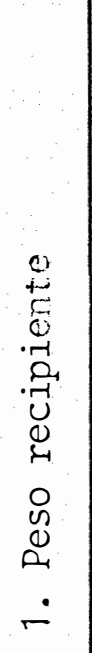 & 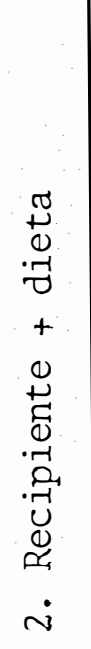 & 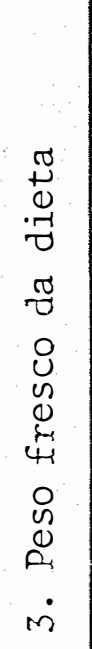 & 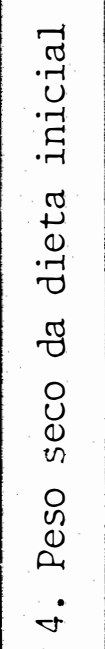 & 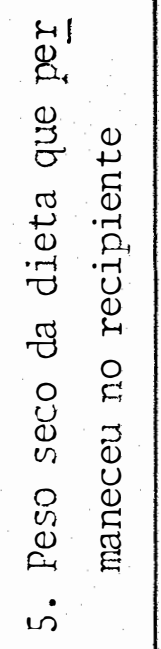 & 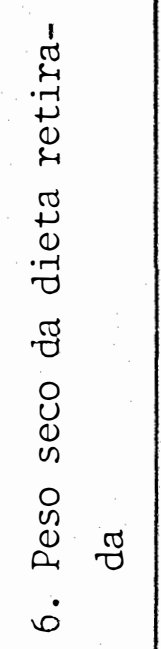 & 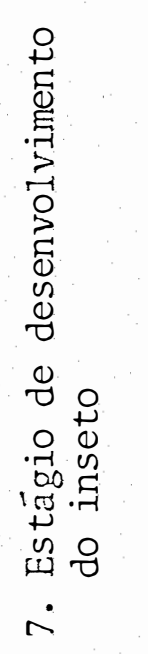 & $\begin{array}{l}0 \\
+ \\
0 \\
w \\
.7 \\
0 \\
0 \\
0 \\
0 \\
0 \\
0 \\
0 \\
\infty \\
0 \\
\infty \\
\infty \\
\infty\end{array}$ & $\begin{array}{l}0 \\
0 \\
N \\
0 \\
4 \\
n \\
\tilde{D} \\
0 \\
0 \\
0 \\
0 \\
0 \\
0 \\
0 \\
0 \\
0 \\
0\end{array}$ \\
\hline Repetições & & & & & & & & & \\
\hline & & & & & & & & & \\
\hline & & & & & & & & & \\
\hline & & & & & & & & & \\
\hline & & & & & & & & & \\
\hline & & & & & & & & & \\
\hline & & & & & & & & & \\
\hline & & & & & & & & & \\
\hline & & & & & & & & & \\
\hline & & & & & & & & & \\
\hline & & & & & & & & & \\
\hline & & & & & & & & & \\
\hline
\end{tabular}




\subsubsection{Análise Protėica}

3.3.4.1. Método de Kjedah1

A análise do teor de proteína nas 4 dietas sele cionadas foi feita através do método de micro-Kjedahl descrito por BATAGLTA et alii (1978), utilizando-se uma concentração de ācido sulfürico de $0,01 \mathrm{~N}$ para a titulação. O volume obtido, em m1, foi multiplicado pelo fator 6,25 para se obter a porcentagem de proteína por mg de dieta.

Foi feita a determinação do teor protéico de la gartas no máximo desenvolvimento. Para avaliar a taxa de eficiência protéica (PER) de $D$. saccharalis, em cada uma das 4 dietas selecionadas, utilizaram-se os dados do teor de proteína de cada dieta, para o cálculo da quantidade de proteína ingerida. A taxa de eficiência protéica é obtida através da seguinte fórmula:

$$
\text { PER }=\frac{\text { ganho de peso da lagarta }}{\text { quantidade de proteína ingerida }}
$$

\subsubsection{Eletroforese}

A eletroforese de disco em gel de poliacrilamida foi utilizada para a determinação da proteína total nas 4 dietas selecionadas. Seguiu-se a metodologia descrita por BRE- 
WER e ASHWORTH (1969), utilizando-se $3 \mathrm{~cm}$ de cada dieta, os quais foram macerados em ägua deionizada. 0 pH do meio era 8,3 e a concentração de poliacrilamida de 7,5\%.

\subsubsection{Custo das 4 Dietas Selecionadas}

0 custo das 4 dietas selecionadas foi feito baseando-se nos preços comerciais de seus componentes (em fevereiro de 1984), nas quantidades utilizadas de cada ingrediente, no consumo alimentar de cada lagarta (item 3.3.3.) ... e na perda d'ägua de cada uma das dietas (item 3.3.3.). Foi feita uma estimativa de custo da dieta para uma produção de 10.000 lagartas de D. saccharalis, baseando-se em Obrigações Reajustäveis do Tesouro Nacional (ORTN).

\subsubsection{Análise Estatística}

Os resultados dos diferentes parâmetros biológ cos estudados nas 4 dietas selecionadas foram submetidos à aná lise de variância, sendo as médias comparadas pelo teste de Tu key, ao nível de 5\% de probabilidade.

Como análise comparativa do desenvolvimento de D. saccharalis nas 4 dietas selecionadas (Unidades Taxonômicas Operacionais - OTU's) envolvendo parâmetros biológicos e nutrí 
cionais conjuntamente realizou-se a "Anälise de Agrupamento" ("cluster analysis") (SNEATH e SOKAL, 1973), sendo necessäria a tranformação dos caracteres (parâmetros biológicos e nutricionais) em vetores binários. Assim, considerando-se o valor médio $(\bar{X})$ de um determinado parâmetro (P) para as 4 dietas selecionadas, tem-se que: $0=\mathrm{P}<\overline{\mathrm{X}}$ e $1=\mathrm{P}>\overline{\mathrm{X}}$.

Os parâmetros empregados nesta análise foram:

\section{(a) biológicos:}

- período larval (dias) (para machos e fêmeas isoladamente) ;

- viabilidade larval $\left(\begin{array}{l}0 \\ 0\end{array}\right)$;

- período pupal (dias) (para machos e fêmeas isoladamente);

- peso de pupas (mg) (para machos e fêmeas isoladamente);

- viabilidade pupal $\left(\begin{array}{l}0 \\ 0\end{array}\right)$;

- longevidade (dias) (para machos e fêmeas isoladamente);

- número médio de ovos por fêmea;

- viabilidade dos ovos $\left(\begin{array}{l}0 \\ 0\end{array}\right)$;

- período de incubação.

(b) nutriciomais:

- ganho de peso da lagarta atê o máximo desenvolvimento (mg);

- alimento consumido pela lagarta atê o máximo desenvolvimento (mg); 
- peso seco das fezes (mg);

- digestibilidade aproximada (AD);

- eficiência de conversão do alimento ingerido (ECI) ;’

- eficiência de conversão do alimento digerido (ECD).

Como anālise complementar, embora sem fundamentos estatísticos teóricos, utilizou-se a anälise dos componentes principais, selecionando três eixos cartesianos ( $x, y$ e z). 


\section{RESULTADOS E DISCUSSÃOO}

\section{1. ia etapa - Fontes Protéicas Variáveis: feijão e milho}

Os resultados dos diferentes parâmetros biológ $\underline{i}$ cos analisados na 1 a etapa são apresentados nas Tabelas 18 a 23 .

As lagartas, que deram origem a machos e fêmeas, apresentaram o maior período larval quando criadas na dieta con tendo milho híbrido. O menor período foi registrado naquela com feijão 'Aroana', sendo que para os machos, o meio contendo 'Ro sinha' também proporcionou um bom desenvolvimento. As dietas tomadas como padrão (Usina Santa Bárbara e HENSLEY e HAMMOND, 1968 ) proporcionaram uma duração intermediária de $D$. sacchara lis, havendo uma tendência de alongamento na primeira dieta (Ta be 1 a 18 ). 
A duração do período larval de $D$. saccharalis na dieta de HENSLEY e HAMMOND (1968) foi de 27,14 dias para os ma chos e 27,95 dias para as fêmeas sendo semelhantes ao valor ob tido por MFLO (1984) que, nas mesmas condições, constatou uma duração de 27,84 dias para machos e fêmeas considerados conjun tamente. Por outro lado, BOWLING (1967) estudando a biologia da broca-da-cana, em dieta artificial contendo feijão, em temperaturas de $26,5 \pm 1,5^{\circ} \mathrm{C}$, obteve um período 1 arval de 30,1 dias, portanto, superioràs durações observadas no presente trabalho para todos os meios que incluíam feijão como fonte protéica (Ta bela 18).

Considerando-se o limite de 5\% como aceitável em termos de contaminação, as dietas que proporcionaram um melhor desenvolvimento da broca poderiam ser excluidas, principalmente aquela com 'Aroana', onde foi constatada uma contaminação de $10,10 \%$ (Tabela 18). Das dietas tomadas como padrão, a da Usina Santa Bárbara foi a melhor delas, com uma contaminação de 4,04\%, sendo que a de HENSLEY e HAMMOND (1968) apresentou uma elevada porcentagem de contaminação por fungos $\left(17,18^{\circ}\right)$, valor este bastante alto se comparado àquele obtido por MÉLO (1984) que, em condições semelhantes, registrou uma contaminação de 6,5\%. Apesar da longa duração da fase larval na dieta com milho híbrido, onde teoricamente haveria mais tempo para que ocorresse a contaminação, a presença de tubos contendo die tas contaminadas foi insignificante. Portanto, não houve re lação entre a duração da fase larval e a ocorrência de fungos (Tabela 18). 
.48 .

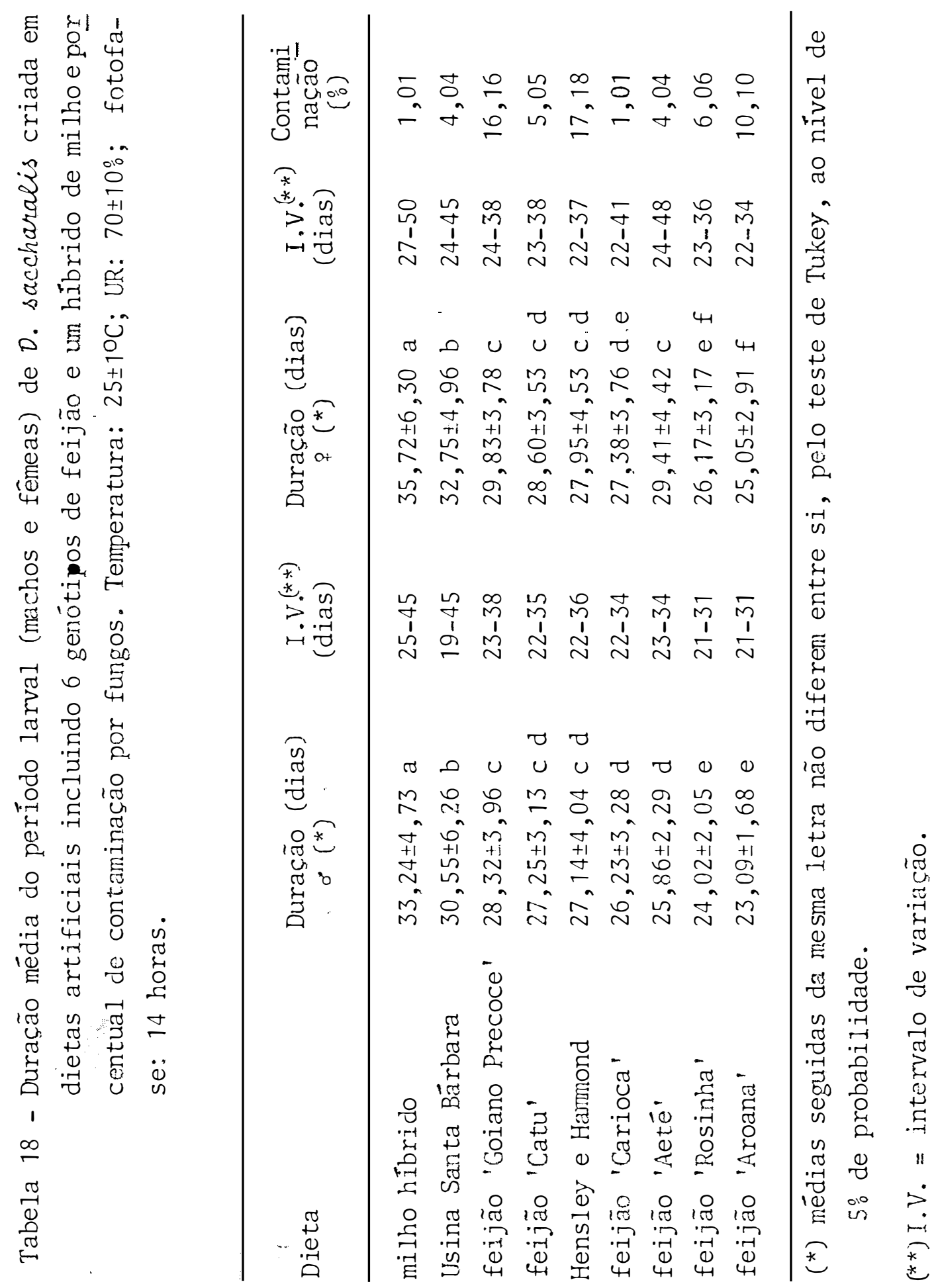


Com relação ao peso de pupas, as dietas tomadas como padrão se destacaram, dando origem a indivíduos com maiores pesos, sendo que aquela contendo milho híbrido foi a que originou as pupas mais leves. Em todos os meios as pupas que originaram fêmeas foram mais pesadas, característica essa bastante marcante em $D$. saccharalis.

Os resultados obtidos na dieta de HENSLEY e HAM MOND (1968) foram pröximos aos relatados por MÉLO (1984). Em relação às dietas incluindo feijão, apesar de terem produzido pupas mais leves do que as obtidas nas dietas tomadas cono pa drão, estes valores foram superiores aos relatados por BOWLING (1967), em pesquisa com dieta contendo feijão. Houve uma marcante influência das variedades sobre o peso de pupas, sen do que o meio artificial contendo feijão 'Aroana' deu origem a pupas (machos) com pesos semelhantes à dieta de HENSIEY e HAMMOND (1968) (Tabe]a 19).

A duração do período pupal em algumas dietas incluindo genótipos de feijão foi menor do que naquelas consideradas como padrão. A dieta de HENSLEY e HAMMOND (1968) propiciou, na presente pesquisa, uma duração maior do que aquela obtida por MELO (1984) que foi de 7,9 e 8,06 dias, para machos o fémeas respectivamente. Nas dietas incluindo genótipos de feijão a duração do período pupal foi superior à referida por BOWLING (1967). Exceto na dieta de HENSLEY e HAMMOND (1968), houve uma tendência da duração do período pupal dos machos ser maior do que a das fêmeas (Tabela 20). 


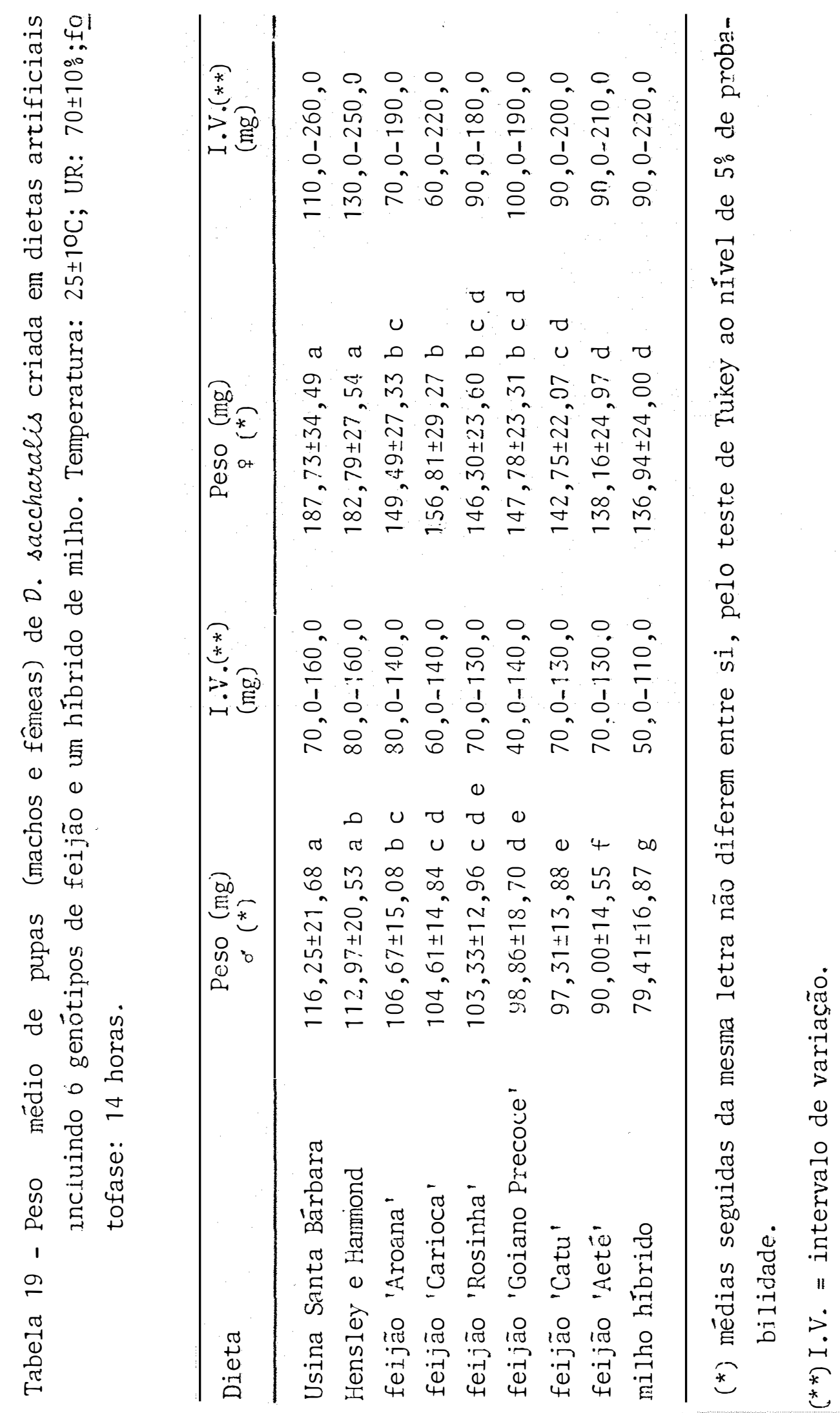




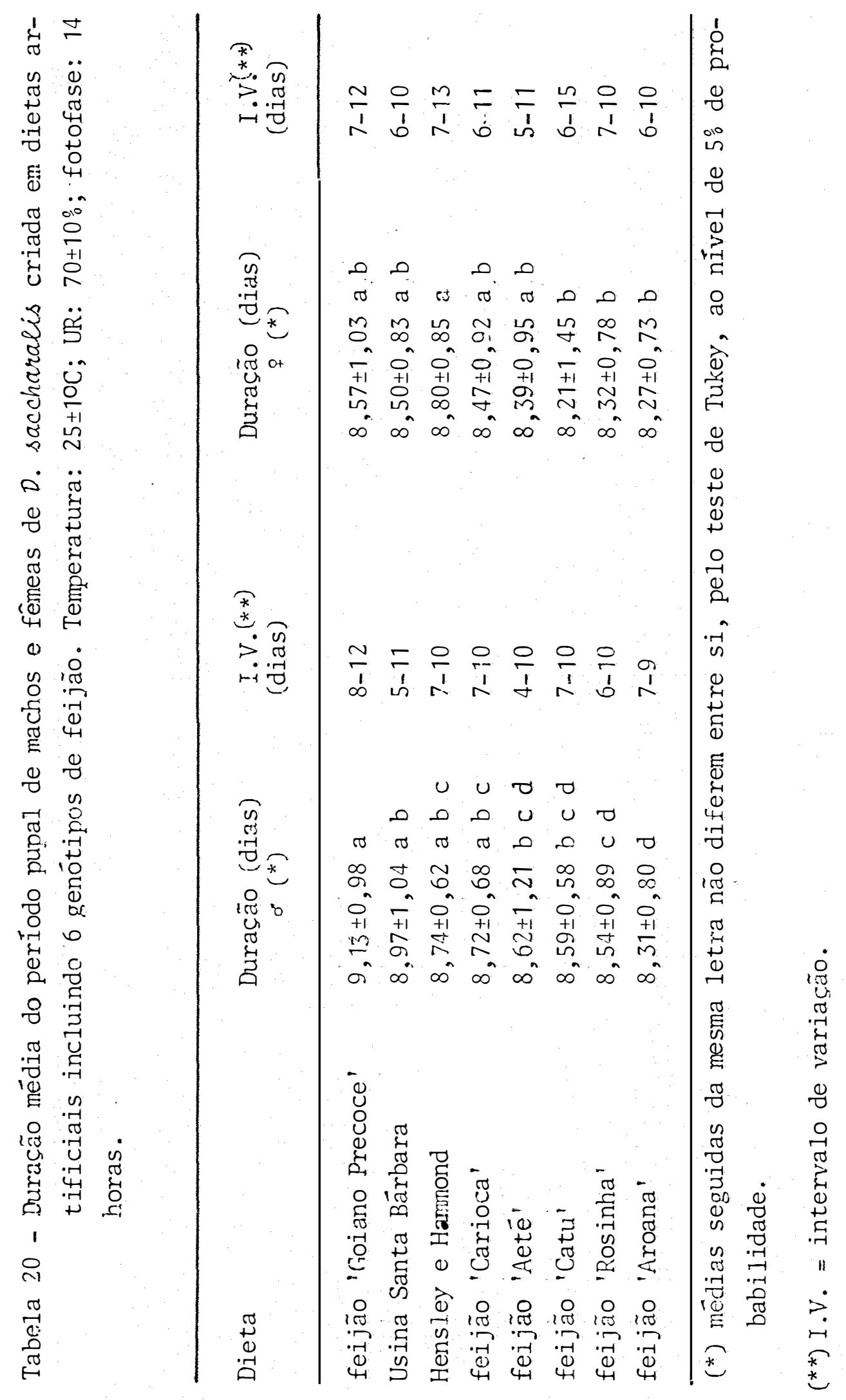


O número reduzido de adultos, obtidos na dieta de milho híbrido, impossibilitou a sua inclusão para a anâlise da duração do período pupal. Para os que emergiram $(28,57 \%$ ' à duração da fase pupal para machos e fêmeas foi de 9,0 e 9,44 dias, respectivamente. Esta baixa viabilidade pupal pode ter sido causada por uma inadequação da dieta, devido a um desbalanceamento de nutrientes ou mesmo falta de algum componente essencial, pois è sabido que os milhos híbridos comuns apresentan uma qualidade protéica inferior e provavelmente, a levedura, utilizada como outra fonte de proteínas (Tabela 4), não foi suficiente para suprir as exigências do inseto.

$$
0 \text { efeito fagoestimulante das dietas, ou seja, as }
$$
características físicas ou químicas que liberaram o comportamento alimentar e que fizeram com que o inseto iniciasse a ali mentação, foi elevado em todas as dietas (Tabela 21). Entretan to, foi nítida a diferença entre as dietas quando se confrontou a viabilidade das diferentes fases. Assim, em termos totais, apenas as dietas com feijão 'Catu', 'Aroana' e 'Rosinha' apresentaram uma viabilidade comparável àquelas tomadas como padrão, e que seriam, baseando-se em SINGH (1983), razoáveis para criações de laboratörio, pois apresentaram uma viabilidade total superior a $75 \%$. A dieta de milho foi a que apresentou a pior performance, principalmente pela alta mortalidade na fa se pupal (Tabela 21). 
Tabela 21 - Efeito fagoestimulante ("pegamento inicial")e viabilidades das diferentes fases de desenvolvimento de $D$. saccharalis cria da em dietas artificiais incluindo 6 genótipos de feijão e um híbrido de milho. Tempera tura: $25 \pm 10^{\circ} \mathrm{C}$; UR: $70 \pm 10^{\circ}$; fotofase: 14 horas.

\begin{tabular}{lcccc}
\hline \multirow{2}{*}{ Dieta } & \begin{tabular}{c} 
Efeito \\
fagoestimu- \\
lante \\
\cline { 5 - 5 }$\left(\begin{array}{c}0 \\
0\end{array}\right)$
\end{tabular} & Larval & Pupal & Total \\
\cline { 5 - 6 } feijão 'Aetē' & 96,97 & 86,87 & 77,91 & 67,68 \\
feijão 'Aroana' & 97,48 & 84,85 & 90,48 & 76,77 \\
feijão 'Carioca' & 92,93 & 86,87 & 74,42 & 64,65 \\
feijão 'Catu' & 98,99 & 92,93 & 86,97 & 80,81 \\
feijão 'Goiano Precoce' & 88,99 & 80,81 & 66,25 & 53,54 \\
feijão 'Rosinha' & 95,96 & 89,89 & 86,52 & 77,78 \\
milho híbrido & 95,96 & 70,71 & 28,57 & 20,20 \\
Hensley e Hammond & 97,98 & 80,81 & 92,50 & 74,75 \\
Usina Santa Báxbara & $\mathbf{8 9 , 9 0}$ & 84,85 & 91,67 & 77,78 \\
\hline
\end{tabular}

A dieta contendo milho híbrido apresentou uma porcentagem elevada de adultos deformados (Tabela 22), confirmando ser inadequada para a criação $D$. saccharalis. O meio de feijão com o genótipo Aroana proporcionou a menor porcentagem de adultos deformados, sendo que os demais meios deram origem a uma porcentagem de deformação próxima àquela registrada nas dietas tomadas como padrão sendo que o valor obtido na de HENS LEY e HAMMOND (1968) foi superior ao encontrado por MELO (1984). 
Tabela 22 - Porcentagem de adultos deformados de $D$. saccharalis obtidos de Iayar as mantidas em dietas artificiais incluindo 6 genótipos de feijão e ui hỉbrido de milho. Temperatura: $25 \pm 10 \mathrm{C}$; UR: $70 \pm$ $10 \%$; fotofase: 14 horas.

Dieta

Adultos deformados ( $\left(\begin{array}{c}0 \\ 0\end{array}\right)$

feijão 'Aetê'

8,96

feijão 'Aroana'

3,95

feijão 'Carioca'

16,67

feijão 'Catu'

5,00

feijão 'Goiano Precoce'

5,66

feijão 'Rosinha'

5,06

milho híbrido

47,62

Hensley e Hamnond

6,76

Usina Santa Bárbara

6,49

Existe uma estreita correlação entre peso de pu pas fêmeas e número de ovos colocados. Assim, considerando-se que mesmo aquelas dietas de feijão ('Catu', 'Aroana' e 'Rosi nha'), que apresentaram viabilidades semelhantes às tomadas como padrão (Tabela 21), deram origem a pupas fêmeas bem mais le ves, nenhuma das dietas utilizadas nesta etapa foi considerada promissora para substituir as convencionais para programas de criação de 0 . saccharalis. 


\subsection{2a etAPA - Fontes PRotéicas VARiáveis: Germe DE tRigo, SOIA, LEVENURA, CASEINA, FEIJÃO E FARELO DE TRIGO}

Os resultados dos diferentes parâmetros biológ cos avaliados na 2 a etapa são apresentados nas Tabelas 23 a 28 .

Foi registrado um menor período larval na dieta da Usina Santa Bārbara (Tabela 23). A menor duração nesta dieta pode ser explicada como uma adaptação das lagartas a este substrato, pois o material biológico utilizado no desenvolvimento do trabalho fora proveniente deste laboratório. A dieta de HENSLEY e HAMMOND (1968) proporcionou um período de desenvolvimento mais longo do que o obtido por MELO (1984), sendo suplantada apenas pelas dietas C (à base de germe de trigo e levedura), E (feijão 'Carioca', germe de trigo e levedura) e da Usina Santa Bārbara. Aparentemente, a combinação do feijão 'Carioca', germe de trigo e levedura estava em proporções balanceadas e proporcionou um ótimo desenvolvimento da broca-da-cana. E sabido que o germe de trigo é uma fonte protéica muito rica, pois contëm todos os nutrientes (18 aminoáci dos comuns, açúcares, triglicerídeos, fosfolipídeos: colina e inositol, vitaminas do complexo B, tocoferol, caroteno, 21 ele mentos minerais e mais de 50 enzimas, com possivel exceção do ácido ascórbico) e tem uma ação fagoestimulante (PARRA, 1979). Esta fonte protéica adicionada ao feijão, aparentemente, supriu às deficiências de alguns aminoácidos (metionina e lis na) apresentadas por esta leguminosa. Alēm disso é provävel que 


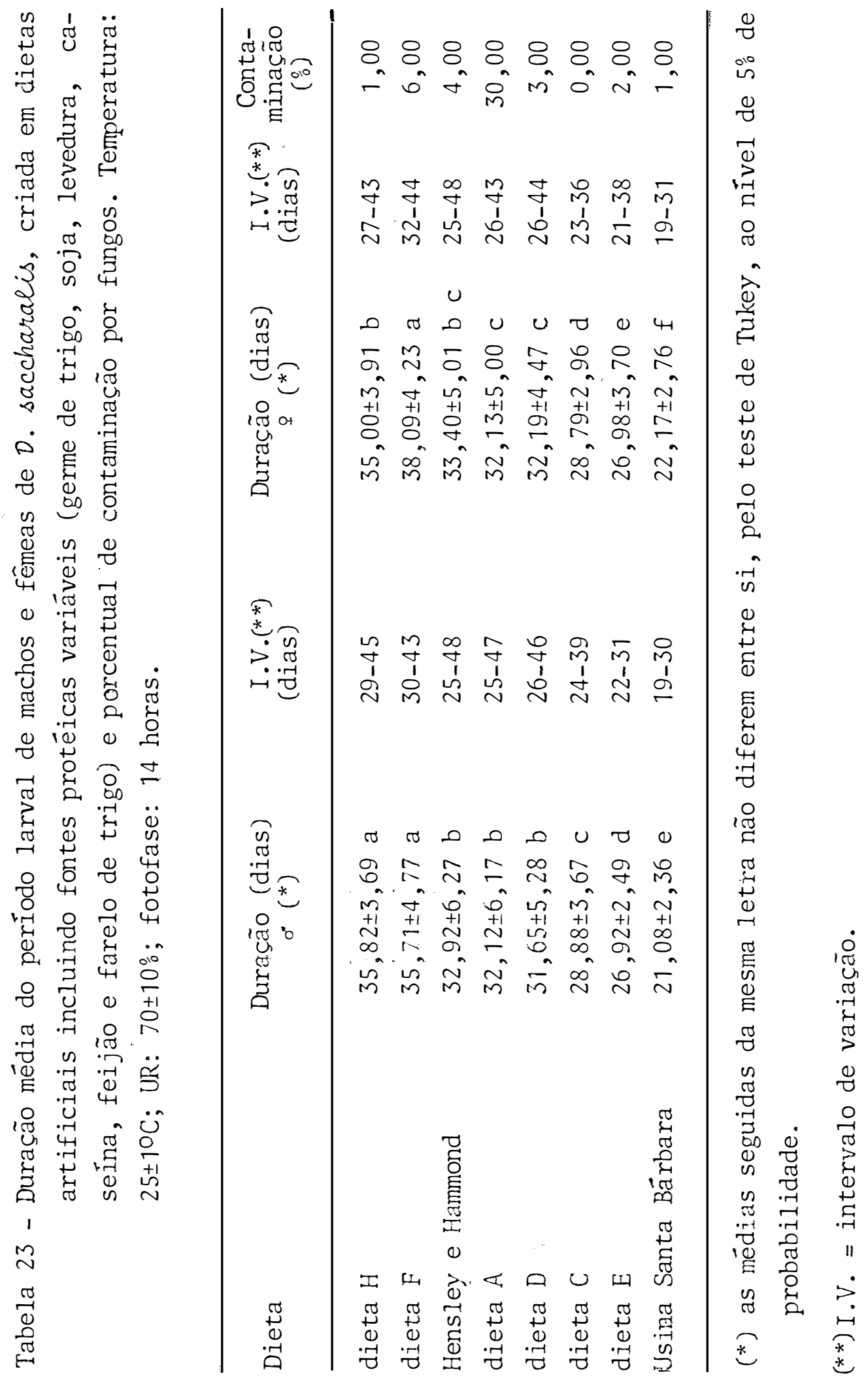


a levedura em combinação à estas 2 fontes, tenham fornecido ou tros aminoácidos, sais minerais e vitaminas indispensáveis ao desenvolvimento de $D$. saccharalis.

Os resultados encontrados por BREWER (1976), à $26 \pm 1{ }^{\circ} \mathrm{C}$, UR: $50 \pm 5^{\circ}$ e fotofase: 14 horas, foram ligeiramente superiores ( 1,5 dias) aos obtidos na presente pesquisa (Tabela 23). Alguns resultados foram discrepantes em relação aos obtidos por outros autores. Assim, BREWER (1976) obteve um período 1a $\underline{\underline{r}}$ val bem mais curto para $D$. saccharalis utilizando a dieta C (à base de germe de trigo e caseína) se comparado ao presente tra balho. Do mesmo modo, as dietas $B$ (à base de germe de trigo e farinha de soja) e G (à base de germe de trigo e farinha de so ja) apresentaram um rendimento tão baixo na presente pesquisa, que foram eliminadas da análise, enquanto o referido autor obteve bons resultados com as mesmas para D. saccharalis. Vários fatores podem ter levado a estas diferenças. Assim, como o estudo de dietas é a nutrição prática, muitas vezes, a forma de preparo do meio, a ordem de colocação dos componentes, a quantidade de água, o tempo de fervura da água, etc, podem alterar uma dieta, e dependendo destes aspectos, ser mais ou menos favorävel a um determinado inseto. Por outro lado, um aspecto que também deve ser levado em consideração é a pureza dos componen tes de dietas utilizados no Brasil. Dado ao preço dos ingredientes, trabalha-se, na maioria das vezes, com componentes não totalmente purificados e que podem muito bem levar a resul tados insatisfatórios (Tabela 23). 
As pupas foram mais pesadas (machos e fêmeas) na dieta padrão utilizada nos laboratórios da Usina Santa Bārbara. A dieta A (à base de farinha de soja e germe de trigo) foi a que apresentou as pupas mais leves.

$$
\text { Em relação à dieta de HENSLEY e HAMMOND }
$$
os resultados foram inferiores aos obtidos por MELO (1984), que relatou pesos de 107,22 e $173,78 \mathrm{mg}$ para machos e fêmeas, respectivamente. Apesar disto, observa-se pela Tabela 24 que foram conseguidas nesta dieta, pupas (fêmeas) com até $250 \mathrm{mg}$, pe so portanto superior ao encontrado em todas as demais dietas. Considerando-se o peso de machos, apenas a dieta $H$ (à base de soja, farelo de trigo e levedura) e a A (à base de germe de trigo e farinha de soja) foram inferiores à de HENSLEY e HAMMOND (1968). Quanto a peso de fêmeas, a estas duas dietas cita das poderia ser adicionada a dieta à base de germe de trigo e caseina (D).

Os resultados referentes à duração do período pupal são provenientes de apenas 6 meios, pois as dietas A (à base de germe de trigo e farinha de soja) e F (à base de germe de trigo e caseína) foran excluídas da análise devido ao pequeno número de adultos emergidos. Não houve influência do meio na duração da fase pupal de fêmeas de $D$. saccharalis (Tabela 25), sen do que para machos apenas a dieta H (à base de soja, farelo de trigo e levedura) proporcionou um alongamento da fase, embora sem diferir dos obtidos na dieta de HENSLEY e HAMMOND (1968) e na dieta $\mathrm{D}$ (germe de trigo e caseína). 


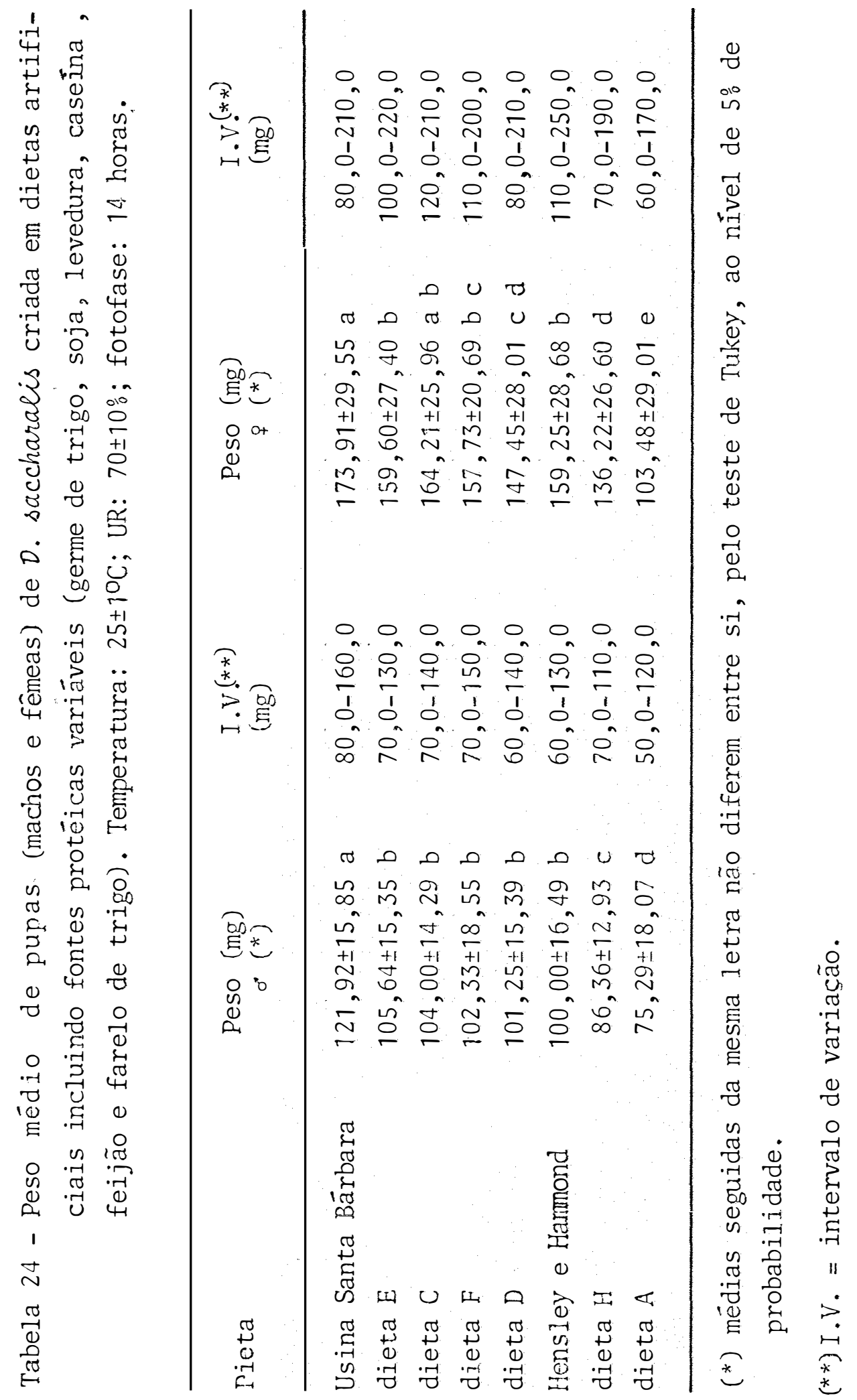


Tabela 25 - Duração média do período pupal de machos e fêmeas de $D$. saccha ralis criada em dietas artificiais incluindo fontes protéicas variáveis (germe de trigo, soja, levedura, caseína, feijão e fa relo de trigo). Temperatura: $25 \pm 1^{\circ} \mathrm{C}$; UR: $70 \pm 10^{\circ}$; fotofase: 14 horas.

\begin{tabular}{|c|c|c|c|c|}
\hline Dieta & $\begin{array}{c}\text { Duração (dias) } \\
0^{*}\left({ }^{*}\right)\end{array}$ & $\begin{array}{l}\text { I.V. }(* *) \\
\text { (dias) }\end{array}$ & $\begin{array}{c}\text { Duração (dias) } \\
o\left({ }^{*}\right)\end{array}$ & $\begin{array}{l}\text { I. } V(* *) \\
(\text { dias })\end{array}$ \\
\hline dieta $\mathrm{H}$ & $9,00 \pm 1,25$ a & $7-11$ & $8,24 \pm 0,66$ a & $7-10$ \\
\hline Hensley e Hammond & $8,65 \pm 0,75$ a b & $8-11$ & $8,24 \pm 0,94$ a & $5-11$ \\
\hline dieta D & $8,53 \pm 1,21$ a b & $6-13$ & $8,26 \pm 0,61 \mathrm{a}$ & $7-10$ \\
\hline Usina Santa Bárbara & $8,41 \pm 0,54 \mathrm{~b}$ & $7-9$ & $8,07 \pm 0,64$ a & $6-10$ \\
\hline dieta $\mathrm{E}$ & $8,33 \pm 0,58 \mathrm{~b}$ & $7-10$ & $8,08 \pm 0,79 a$ & $5-10$ \\
\hline dieta $\mathrm{C}$ & $8,24 \pm 0,75 b$ & $7-11$ & $8,16 \pm 0,45$ a & $7-9$ \\
\hline
\end{tabular}

(*) médias seguidas da mesma letra não diferem entre si, pelo teste de Tukey, ao nivel de 5: de probabilidade.

$(* *)$ I.V. = intervalo de variação.

Os meios que apresentaram efeitos fagoestimulan tes inferiores a $80 \%$ (inadequados para grandes criações) foram aqueles à base de germe de trigo e farinha de soja (A), base de germe de trigo e caseína (F) e com farelo de trigo, soja e levedu ra (H). As dietas C (à base de germe de trigo e levedura), D (germe de trigo e caseína) e E (feijão 'Carioca', germe de trí go e levedura) (Tabela 26) foram comparáveis ou superiores àquelas tomadas como padrão.

Pela viabilidade total (lagarta-adulto) 4 dietas têm potencial para criação de 0 . saccharalis: a dieta pa- 
drão utilizada nos laboratórios da Usina Santa Bárbara, a que inclui feijão 'Carioca', germe de trigo e levedura (E), aquela à base de germe de trigo e caseína (D) e a padrão de HENSLEY e HAMMOND (1968) (Tabela 26).

Tabela 26 - Efeito fagoestimulante ("pegamento inicial") e viabilida des das diferentes fases do desenvolvimento de $D$. saccharalis, criada em dietas artificiais incluindo fontes protéicas variáveis (germe de trigo, soja, levedura, caseína, feijão e farelo de trigo). Temperatura: $25 \pm 1^{\circ} \mathrm{C}$; UR: $70 \pm 10^{\circ}$; fotofase: 14 horas.

\begin{tabular}{lcccc}
\hline Dieta & $\begin{array}{c}\text { Efeito fa- } \\
\text { goestimulan } \\
\text { te }\left(\begin{array}{c}0 \\
0\end{array}\right)\end{array}$ & \multicolumn{3}{c}{ Viabilidade $\left(\begin{array}{c}(0 \\
0\end{array}\right)$} \\
\hline dieta A & 75,00 & 40,00 & 35,00 & 14,00 \\
dieta C & 94,00 & 78,00 & 82,05 & 64,00 \\
dieta D & 95,00 & 87,00 & 94,25 & 82,00 \\
dieta E & 99,00 & 89,00 & 97,75 & 87,00 \\
dieta F & 51,00 & 39,00 & 94,87 & 37,00 \\
dieta H & 67,00 & 59,00 & 67,80 & 40,00 \\
Hensley e Hanmond & 86,00 & 79,00 & 96,20 & 76,00 \\
Usina Santa Bärbara & 98,00 & 94,00 & 98,94 & 93,00 \\
\hline
\end{tabular}

Considerando-se o nümero de adultos deformados, pode-se observar que a dieta de germe de trigo e farinha de so ja (A) não é favorável para D. saccharalis, pois neste meio foram encontrados $20 \%$ de adultos deformados. Por outro lado, as 
dietas D (germe de trigo e caseína) e E (feijão Carioca, germe de trigo e levedura) mostraram-se promissoras para criação do inseto, principalmente aquela que incluía feijão 'Carioca'·(Tabela 27). Tendo em vista o maior peso de pupas fêmeas obtidas na dieta $E$, selecionou-se este meio para comparação final, em relação à dieta $D$.

Tábela 27 - Porcentagem de adultos deformados de D. saccharalis obtidos de lagartas mantidas em dietas artificiais incluindo fontes protéicas variáveis (germe de trigo, soja, levedura, caseína, fei jão e farelo de soja). Temperatura: $25 \pm 10 \mathrm{C}$; UR: $70 \pm 10 \%$; fotofa se: 14 horas.

Dieta

Adultos deformados

$(\%)$

dieta $\mathrm{A}$

20,00

dieta C

7,81

dieta $\mathrm{D}$

2,41

dieta $E$

1,15

dieta $\mathrm{F}$

2,70

dieta $\mathrm{H}$

10,00

Hensiey e Hammond

5,26

Usina Santa Bärbara

0,00 


\subsection{3a ETAPA - Fontes Protéicas VARIÁveis: SOJA e Milho}

Os resultados biológicos obtidos na 3ạ etapa são apresentados nas Tabelas 28 a 32 .

As dietas que proporcionaram um menor período larval e portanto interessantes para programas de criação foram $\underline{\text { a }}$ quelas tomadas como padrão e a que incluía milho. 'Nutrimaiz'. Os resultados obtidos em relação a dieta de HENSLEY e HAMMONI (1968) foram semelhantes aos de MÉLO (1984), que obteve um período larval médio de 27,84 dias, para machos e fêmeas conjuntamente. As dietas incluindo genótipos de soja propiciaram durações mais longas, inłicando a sua inadequação para a criação da broca-da-cana (Tabela 28).

A dieta padrão da Usina Santa Bárbara foi a mais favorável à criação de lagartas de D. saccharalis. A seguir, vieram as dietas de HENSLEY e HAMMOND (1968) e a dieta de mitho 'Nutrimaiz' que não diferiram entre si.

As dietas tomadas como padrão de HENSLEY e HANMOND (1968) e da Usina Santa Bárbara, juntamente com a dieta de milho 'Nutrimaiz', foram aquelas que não apresentaram conta minação por fungos, característica essa favorável a grandes criações de laboratório. Das dietas incluindo genötipos de soja, apenas a de 'IAC2' não apresentou contaminação (Tabela 28).

Os meios contendo os genótipos IAC7 e IAC773090

foram eliminados das anälises porque não proporcionaram a complementação da fase larval de nenhum inseto. 


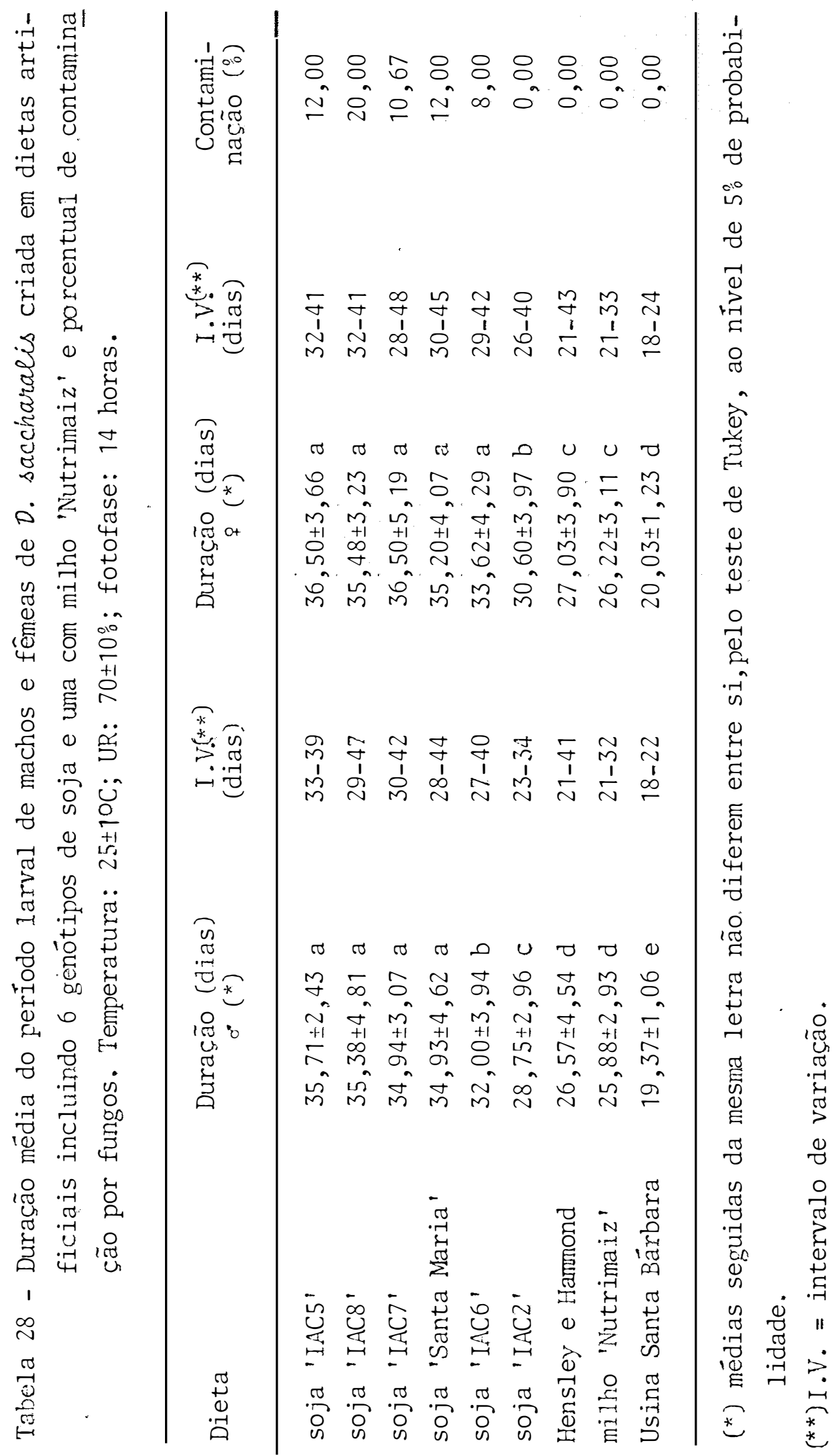


Baseando-se no peso das pupas pode-se observar o bom desempenho da dieta incluindo milho 'Nutrimaiz'. Nesta dieta foram obtidos machos e fêmeas mais pesados, embora não diferenciando da dieta utilizada nos laboratórios da Usina Santa Bärbara e sendo superior à dieta de HENSLEY e HAMMOND (1968). Ape nas a dieta com o genótipo IAC2 foi comparável ao padrão de HENSLEY E HAMMOND (1968) (Tabela 29).

Os insetos mantidos na dieta com 'Nutrimaiz' apresentaram o maior período pupal, com um valor constante para machos e fêmeas, porém 1,79 dias mais longo do que os valores registrados no meio da Usina Santa Bärbara (Tabela 30).

Devido ao número reduzido de adultos emergidos, excluíram-se as dietas com os genötipos de soja IAC5, IAC6, IAC7 e IAC8, da comparação de médias das durações do período pupal.

As dietas tomadas como padrão e a de milho 'Nutrimaiz' apresentaram características que proporcionaram um bom "pegamento inicial", enquanto aquelas com genótipos de soja, desde o início, foram inadequadas para a criação da broca-da-cana (Tabela 31). Na viabilidade total confirmou-se a supe rioridade das dietas tomadas como padrão e da de milho 'Nutrimaiz' (Tabela 31). 


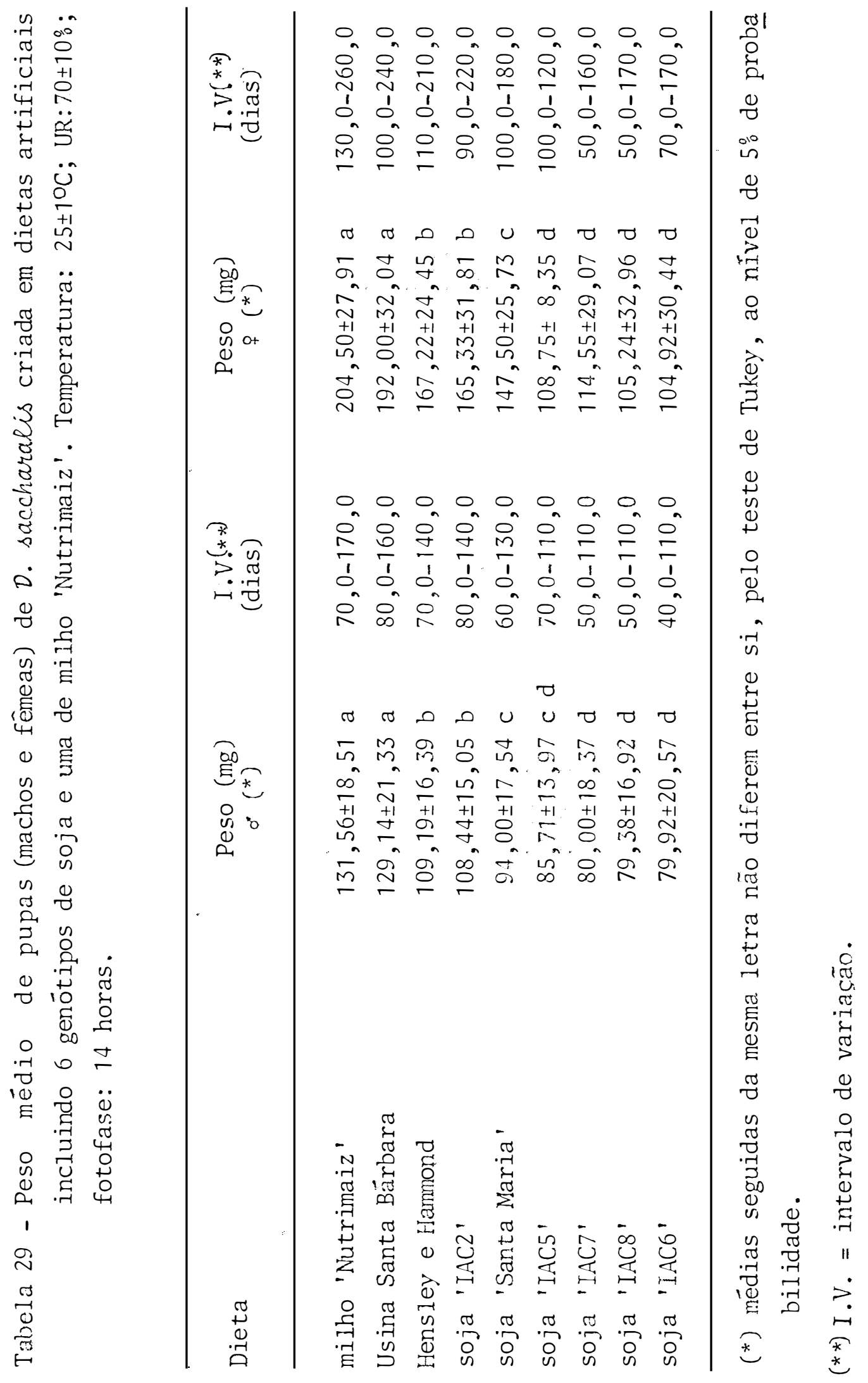


Tabela 30 - Duração média do período pupal de machos e fêmeas de D. saccha ralis criada em dietas artificiais incluindo 2 genótipos de so

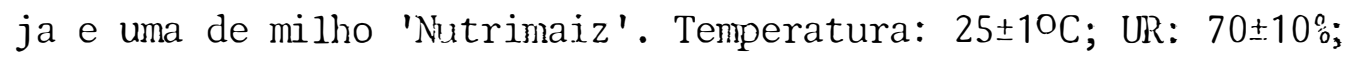
fotefuse: 14 horas.

\begin{tabular}{lcccc}
\hline Dieta & $\begin{array}{c}\text { Duração (dias) } \\
0^{*}(*)\end{array}$ & $\begin{array}{c}\text { I.V. }(* *) \\
(\text { dias })\end{array}$ & $\begin{array}{c}\text { Duração (dias) } \\
+(*)\end{array}$ & $\begin{array}{c}\text { I.V. } .^{(* *)} \\
(\text { dias })\end{array}$ \\
\hline soja 'Santa Maria!: & $9,38 \pm 0,88 \mathrm{a}$ & $8-11$ & $8,86 \pm 0,50 \mathrm{~b}$ & $8-10$ \\
milho 'Nutrimaiz' & $9,29 \pm 0,78 \mathrm{a}$ & $7-11$ & $9,29 \pm 0,73 \mathrm{a}$ & $7-10$ \\
soja 'IAC2' & $8,75 \pm 0,93 \mathrm{~b}$ & $7-11$ & $8,48 \pm 0,82 \mathrm{~b}$ & $6-10$ \\
Hensley e Hammond & $8,29 \pm 0,68 \mathrm{c}$ & $7-9$ & $8,09 \pm 0,75 \mathrm{c}$ & $6-10$ \\
Usina Santa Bärbara & $7,50 \pm 0,55 \mathrm{~d}$ & $7-9$ & $7,50 \pm 0,56 \mathrm{~d}$ & $7-9$ \\
\hline
\end{tabular}

(*) médias seguidas da mesma letra não diferem entre si, pelo teste de Tukey, ao nível de 5\% de probabilidade.

$\left({ }^{* *}\right)$ I.V. = intervalo de variação.

Com relação às características do adulto, os meios de HENSLEY e HAMNOND (1968) e o de milno 'Nutrimaiz', fo ram os melhores, pois deram origem a $100 \%$ de adultos normais, ou seja, sem déformações nas asas (Tabela 32). Das dietas com soja, apenas aquela com 'IAC2' proporcionou uma pequena porcen tagem de adultos deformados, inferior àquela obtida na dieta padrão da Usina Santa Bärbara (Tabela 32). 
Tabela 31 - Efeito fagoestimulante ("pegamento inicial") e viabilida des das diferentes fases do desenvolvimento de $D$. saccharalis, criada em dietas artificiais incluindo 6 genötipos de soja e una de milho 'Nutrimaiz'. Tenperatura: $25 \pm 10^{\circ} \mathrm{C}$; UR: $70 \pm 10^{\circ}{ }^{\circ}$; fotofase: 14 horas.

\begin{tabular}{lcccc}
\hline Dieta & $\begin{array}{c}\text { Efeito fa- } \\
\text { goestimulan- } \\
\text { te }\left(\begin{array}{c}\circ \\
0\end{array}\right)\end{array}$ & \multicolumn{2}{c}{ Viabilidade $\left(\begin{array}{l}0 \\
0\end{array}\right)$} & \\
\cline { 4 - 5 } & & Larval & Pupal & Total \\
\hline soja 'IAC2' & 82,67 & 82,67 & 85,48 & 70,67 \\
soja 'IAC5' & 32,00 & 20,00 & 26,67 & 5,33 \\
soja 'IAC6' & 65,35 & 34,67 & 26,92 & 9,33 \\
soja 'IAC7' & 68,00 & 52,00 & 41,02 & 21,33 \\
soja 'IAC8' & 69,33 & 49,33 & 21,62 & 10,67 \\
soja 'Santa Maria' & 78,67 & 66,67 & 64,00 & 42,67 \\
milho 'Nutrimaiz' & 96,00 & 96,00 & 93,06 & 89,33 \\
Hensley e Hammond & 97,33 & 97,33 & 91,78 & 89,33 \\
Usina Santa Bärbara & 100,00 & 100,00 & 89,33 & 89,33 \\
& & & & \\
\hline
\end{tabular}

Assim, analisando-se todos os parâmetros biológicos obtidos nesta etapa, pode-se concluir que a dieta de milho 'Nutrimaiz' tém características propícias para a criação da broca-da-cana. Embora o milho comum seja una fonte de qualidade protêica inferior, obteve-se con o citado meio, umbom desenvolvimentode $D$. saccharalis, porque o milho 'Nutrimaiz' é qualitativamente su- 
perior pelos niveis de lisina e triptofano (Tabela 15). Alëm disto, o germe de trigo e levedura são fontes protéicas ricas e suplementam as eventuais deficiências existentes. A dieta não apresentou problemas de contaminação por fungos (Tabela 28), sendo de fäcil preparo e constituída de componentes de baixo custo e facilmente adquiriveis no mercado, atendendo, deste mo do, aos objetivos do presente trabalho.

Tabela 32 - Porcentagem de adultos deformados de $D$. saccharalis obtidos de lagartas mantidas em dietas artificiais incluindo 6 genótipos de soja e uma de milho 'Nutrinaiz'. Temperatura: $25 \pm 1^{\circ} \mathrm{C}$; UR: $70 \pm 10 \%$; fotofase: 14 horas.

Dieta

Adultos deformados

$(\%)$

$\begin{array}{lr}\text { soja 'IAC2' } & 1,89 \\ \text { soja 'IAC5' } & 50,00 \\ \text { soja 'IAC6' } & 28,57 \\ \text { soja 'IAC7' } & 6,25 \\ \text { soja 'IAC8' } & 11,11 \\ \text { soja 'Santa Maria' } & 21,87 \\ \text { milho 'Nutrimaiz' } & 0,00 \\ \text { Hensl ey e Hammond } & 0,00 \\ \text { Usina Santa Bärbara } & 3,08\end{array}$


As dietas dos genótipos de soja foram desfavoräveis para a criação de $D$. saccharalis. Apesar da soja apresentar teores protéicos elevados, esta leguminosa não se mostrou adequada para a elaboração de dietas para a broca - da - cá na, inclusive chegando em certos casos, a dar uma porcentagem elevada de adultos deformados (Tabela 32).

Apenas o genótipo IAC2 merece ser estudado com mais detalhes (Tabelas 28 a 32 ), embora tenha proporcionado uma viabilidade total inferior a 75\%. As dietas contendo soja poderiam, em pesquisas futuras, serem preparadas com grãos descascados, pois no presente trabalho, os grãos foram moídos integralmente. Segundo alguns autores, as cascas poderiam conter residuos prejudiciais aos insetos. Além disto, a suplementação protéica foi pobre, utilizando-se apenas levedura; possivelmente, melhores resultados pudessem ser alcançados se se adicionasse outra fonte como o germe de trigo, por exemplo.

\subsection{4a eTAPA - Fonte Protéica Variável: milho}

A fonte protéica variävel desta etapa foi o milho e os resultados obtidos em relação aos 5 genótipos estudados, são apresentados nas Tabelas 33 a 38 .

A dieta incluindo o genótipo VD-2 $\mathrm{br}_{2}{ }^{+}$ocorreu o menor período de desenvolvimento larval, tanto para ma- 
chos como fêmeas. Na dieta de HENSLEY e HAMMOND (1968) registrou-se um período larval menor do que o obtido por MÉLO (1984). Pe los resultados obtidos as dietas à base de milho se mostraram mais uma vez promissoras para criação da broca-da-cana.

A maior porcentagem de contaminação por fungos foi encontrada na dieta incluindo o genótipo VDwx e a menor foi naquela com 'Nutrimaiz' (Tabela 33).

Para o peso de pupas que darão origem a machos, observou-se o bom crescimento na dieta de milho 'VD-br $2_{2}{ }_{2}$ ', enquanto que para aquelas que darão fêmeas, o melhor resultado foi otido com a dieta de HENSLEY e HAMMOND (1968). As dietas de milho de ram origem a pupas que se apresentaram dentro dos padrões normais de peso, sendo que na presente pesquisa, os valores na dieta de HENSLEY e HAMMOND (1968) foram muito superiores aos registrados por MELO (1984), o qual encontrou pesos de fêmeas semelhantes aos obtidos no meio com 'Nutrimaiz' (Tabela 34 ).

A maior duração do período pupal foj registrada na dieta com milho 'Nutrimaiz', semelhante à dieta da Usina Santa Bärbara, porëm superior em 1,12 dias (machos) e 0,33 dias (fêmeas) à duração encontrada na dieta de HENSLEY e HAMMOND (1968) (Tabela 35).

Os níveis de deformação de adultos nas dietas to madas como padrão foram superiores à maioria das dietas com mi 1ho, exceto. 'VDwx' e VD-2 $\mathrm{br}_{2}{ }^{+}$', sendo que o meio com 'Nutri maiz' foi apenas suplantado pelo 'VD-br $2_{2} \mathrm{O}_{2}$ (Tabela 36). 


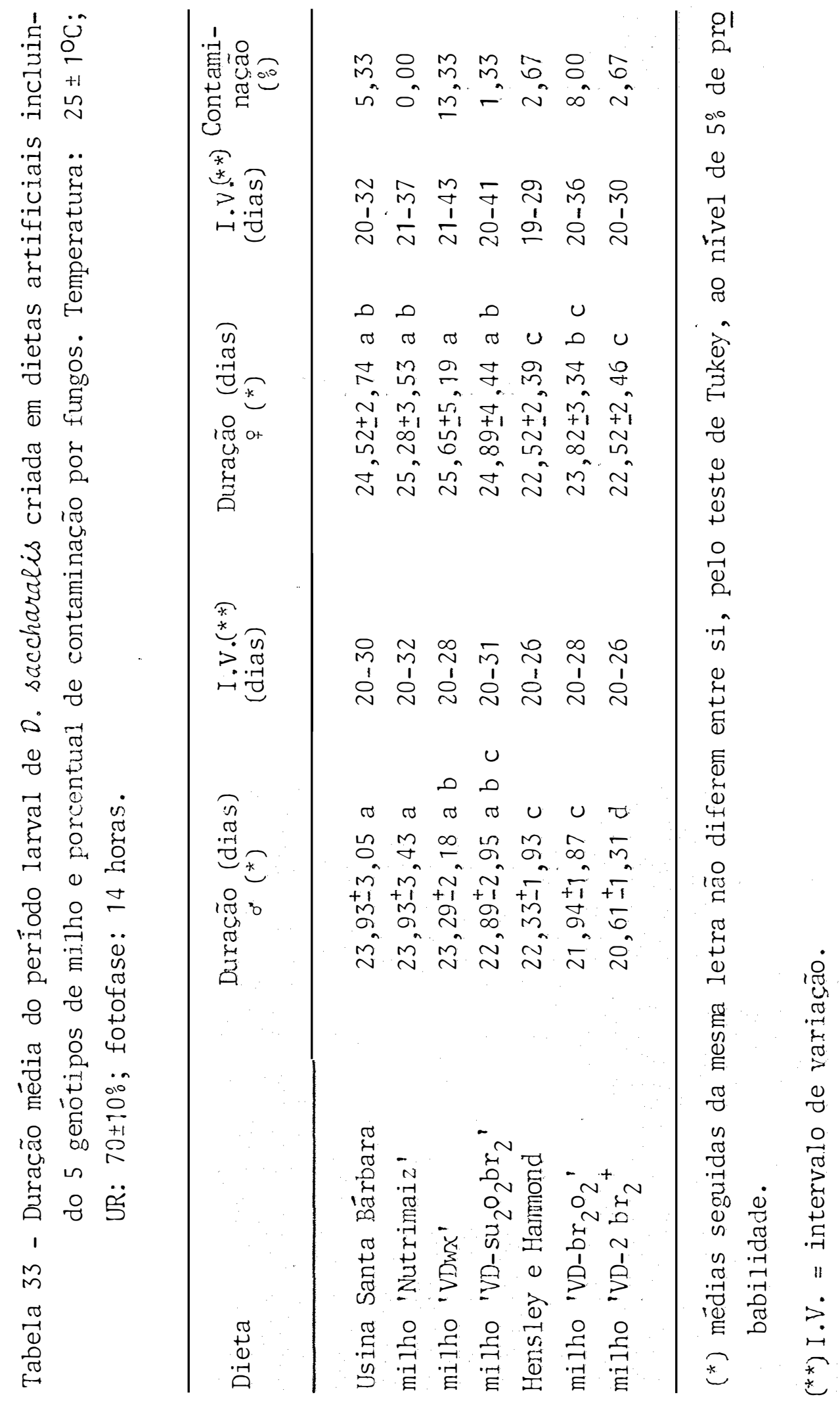




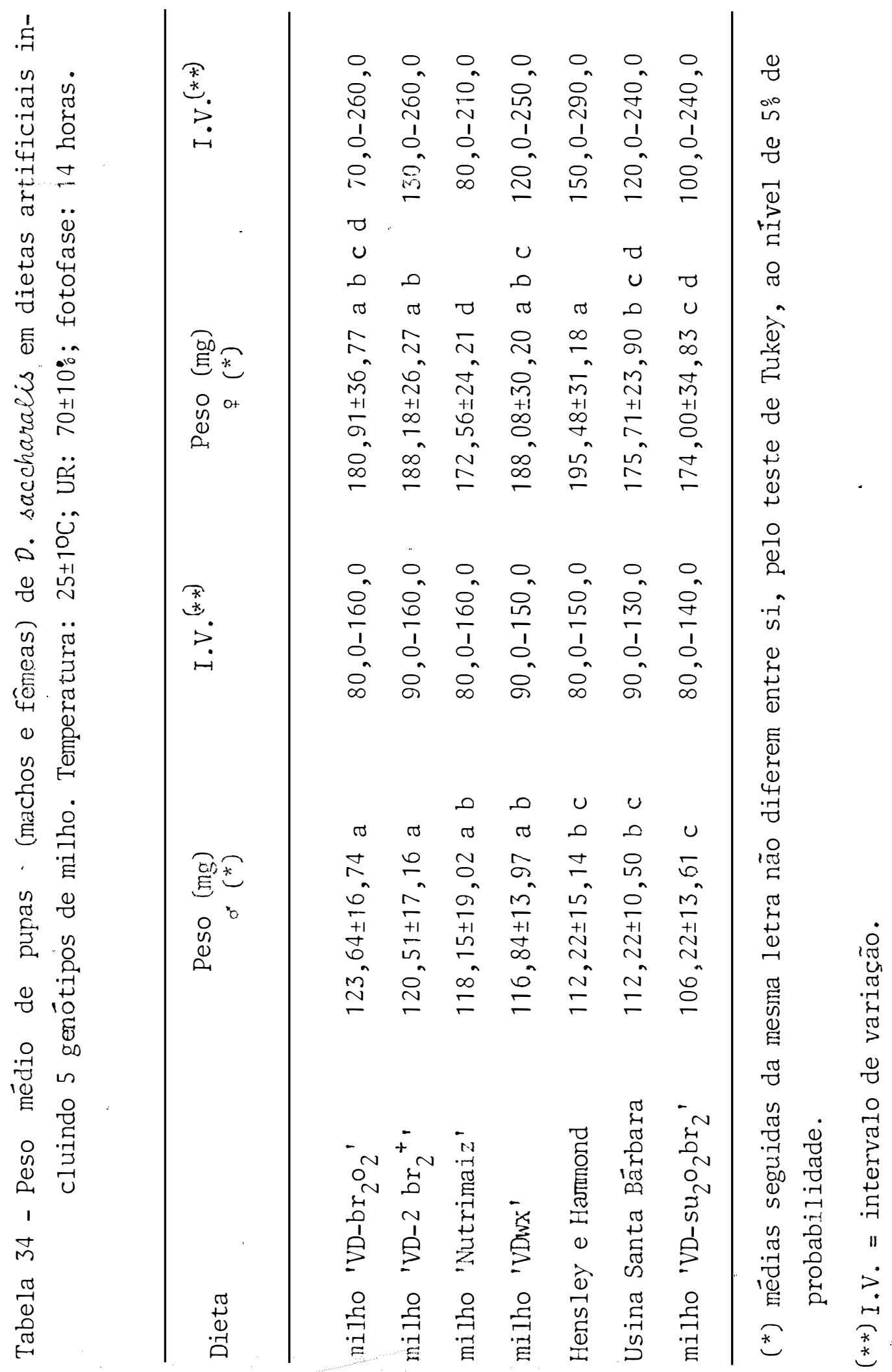




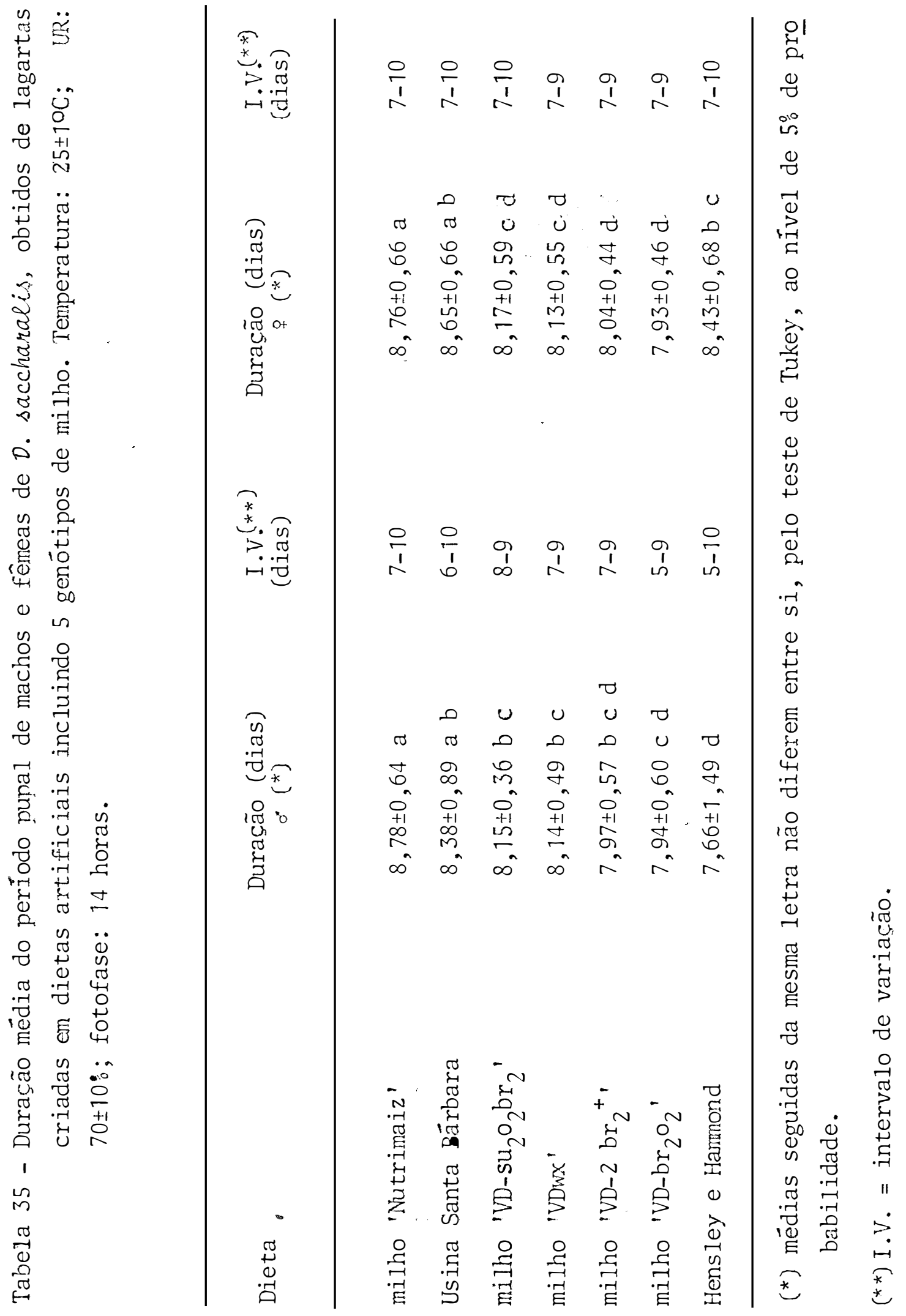


Tabela 36 - Porcentagem de adultos deformados de $D$. saccharalis criada em dietas artificiais, incluindo 5 genötipos de milho. Temperatura: $25 \pm 10^{\circ} \mathrm{C}$; UR: $70 \pm 10^{\circ}$; fotofase: 14 horas.

\begin{tabular}{lc}
\hline Dieta & Adultos deformados \\
\hline milho 'VDwx' & 5,17 \\
milho 'VD-su ${ }_{2}^{\circ} \mathrm{O}_{2} \mathrm{br}_{2}$ ' & 3,17 \\
milho 'VD-2 $\mathrm{br}_{2}{ }^{+,}$ & 9,68 \\
milho 'VD-br${ }_{2}{ }_{2}$ ' & 1,64 \\
milho 'Nutrimaiz' & 2,89 \\
Hensley e Hanmond & 4,61 \\
Usina Santa Bärbara & 3,03 \\
\hline
\end{tabular}

0 efeito fagoestimulante de todas as dietas com genótipos de milho foi elevado, indicando a sua possível utilí zação para a criação da broca-da-cana. A maior viabilidade total foi obtida na dieta incluindo milho 'Nutrimaiz' e a menor naquela com o genótipo VDwx (Tabela 37). 
Tabela 37- Efeito fagoestimulante ("negamento inicial"). e viabilidades das diferentes fases do desenvolvimento de $D$. saccharalis, criada em dietas artificiais incluindo 5 genótipos de milho. Temperatura: $25 \pm 1{ }^{\circ} \mathrm{C}$; UR: $70 \pm 10 \%$; fotofase: 14 horas.

\begin{tabular}{|c|c|c|c|c|}
\hline \multirow{2}{*}{ Dieta } & \multirow{2}{*}{$\begin{array}{c}\text { Efeito fa } \\
\text { goestimu- } \\
\text { lante } \\
\left(\begin{array}{l}0 \\
0\end{array}\right)\end{array}$} & \multicolumn{3}{|c|}{ Viabilidade $\left(\frac{\%}{0}\right)$} \\
\hline & & Larval & Pupal & Total \\
\hline milho 'VDwx' & 98,67 & 86,49 & 90,63 & 77,33 \\
\hline milho 'VD-su ${ }_{2} \mathrm{O}_{2} \mathrm{br}_{2}{ }^{\prime}$ & 97,33 & 98,63 & 87,50 & 84,00 \\
\hline milho 'VD-2 $\mathrm{br}_{2}{ }^{+}$ & 100,00 & 96,00 & 86,11 & 82,67 \\
\hline milho 'VD-br $2_{2}{ }_{2}^{\prime}$ & 100,00 & 88,00 & 92,42 & 81,33 \\
\hline milho 'Nutrimaiz' & 96,00 & 93,33 & 98,57 & 92,00 \\
\hline Hensley e Hamonond & 96,00 & 89,33 & 97,02 & 86,67 \\
\hline Usina Santa Bārbara & 94,67 & 92,00 & 95,65 & 88,00 \\
\hline
\end{tabular}


SINGH (1983) considerou que, para que uma dieta seja considerada adequada, ela deve apresentar uma viabilidade superior a $75 \%$; baseando-se neste valor, nota-se que todas as dietas cerian adoquada para it criação da broca-da-cana (Tabela 37). 0 mi lho é uma fonte qualitativamente pobre de proteínas, devido a deficiên cia dos aminoácidos lisina e triptofano, apresentando, em média, $10 \%$ de proteinas, com $50 \%$ dessa porcentagem representada por zeína. Assim, a eficiência dos meios com milho, como 'VD-br ${ }_{2} \mathrm{O}_{2}$ ', deve-se ao aumento em Iisina pela redução da zeína e conseqüen te aumento nas frações albumina, globulina e glutelina (Jimenes, 1966; Mossé, 1966; Mossé et alii, 1966, citados por TOSEL LO, 1980). Tambêm, no caso do genótipo Nutrimaiz, o perfil de aminoácidos indica um aumento no teor de lisina $(4,35 \%)$ e de triptofano $(1,01 \%$ ) e redução no teor de leucina $(7,47 \%$ ) (SILVA et alii, 1978).

Pelos resultados obtidos e devido a disponibili dade de material durante a condução do experimento, optou - se pelo uso do genótipo Nutrimaiz para o prosseguimento do traba Tho (item 4.5.).

\subsection{COMPARAÇ̃̃O DAS 4 DIETAS SELECIONADAS}

Foram selecionadas das etapas 2,3 e 4 as seguin tes dietas: E (à base de feijāo 'Carioca', germe de trigo e 1e vedura) e aquela de milho 'Nutrimaiz', germe de trigo e levedu ra, alêm das duas dietas consideradas como padrão de comparação. 


\subsubsection{Fase Larva1}

\subsubsection{Duração e viabilidade}

Para lagartas que deram origem a fêmeas as dietas tomadas cono padrão foram as mais adequadas, já que nas mesmas foram observados os menores valores para a duração do periodo larval. Para aquelas que originaram machos, a dieta da Usina Santa Bárbara foi a que promoveu o mais rápido desenvolvimento. A dieta E (à base de feijão 'Carioca', germe de trigo e levedura) alongou demasiadamente o período em 6 e 5,12 dias para machos e fêmeas, respectivamente, em relação à dieta da Usina Santa Bárbara. O meio com milho 'Nutrimaiz' foi superior à dieta E e inferior àqueles tomados como padrão de compa ração (Tabela 38).

A viabilidade larval foi alta nos 4 meios estudados, apresentando-se maior na dieta com milho 'Nutrimaiz'. Por sua vez, esta dieta não apresentou tubos contaminados por fungos, sendo que a contaminação mais elevada foi registrada na dieta padrão de HENSLEY e HAMMOND (1968) (Tabela 38). 
. 79.

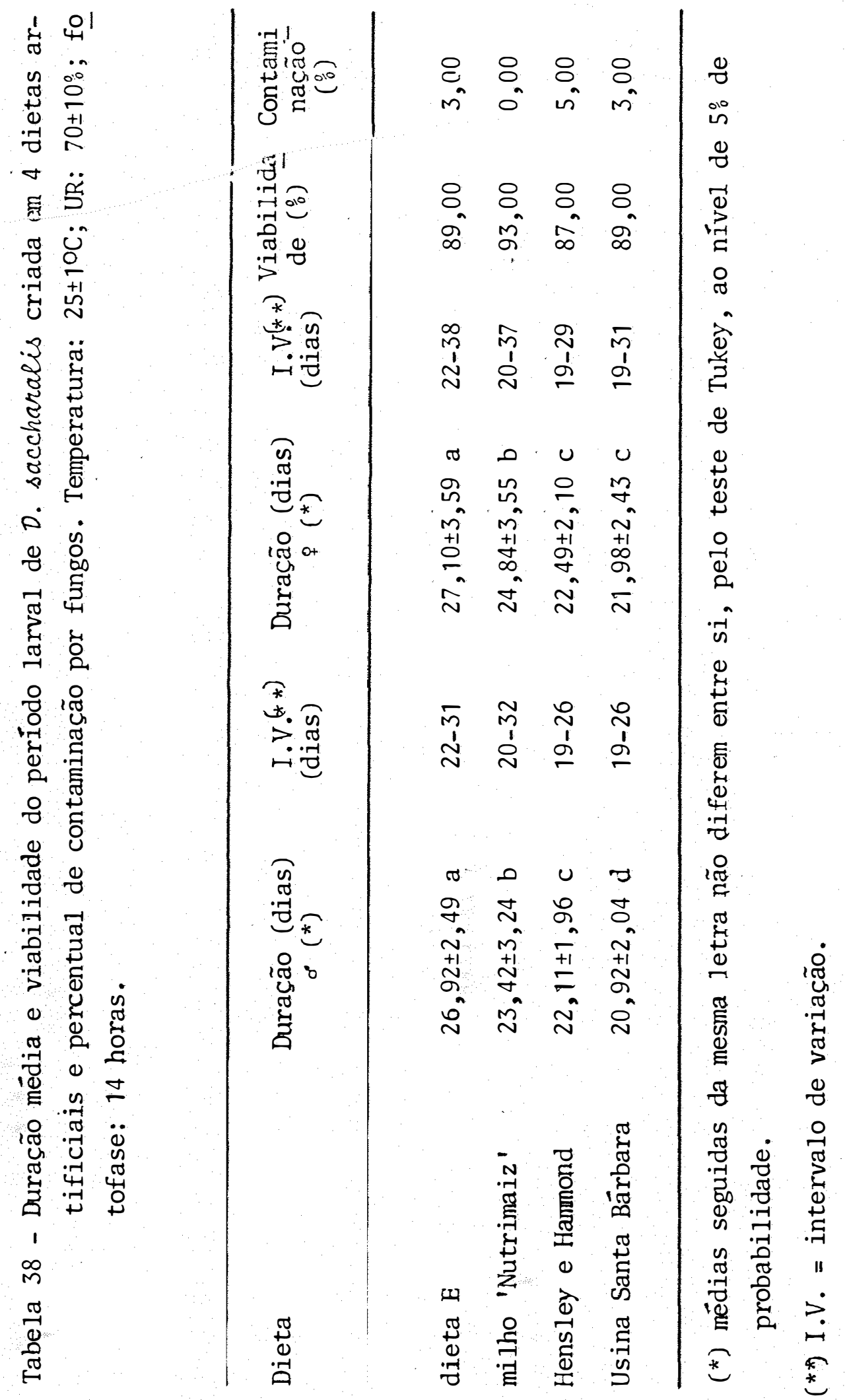


4.5.1.2. Número e duração dos instares larvais nas 4 dietas selecionadas

As larguras das cápsulas cefálicas, o número de instares e a duração de cada instar, com as respectivas razões de crescimento, nas 4 dietas selecionadas, são apresentados nas Tabelas 39 a 42 .

As dietas não afetaram o número de instares de D. saccharalis, sendo que nos 4 meios, as lagartas apresentaram 5 ou 6 instares (Tabelas 39 a 42). O que variou foi a porcentagem de lagartas que apresentaram 5 ou 6 instares em cada um dos substratos (Tabela 43).

Tabela 39 - Largura média da cápsula cefâlica, razão de crescimento e dura ção de cada instar de 10 lagartas de $D$. saccharalis criadas em dieta artificial de HENSLEY e HAMMND (1968). Temperatura: 25 \pm $1^{\circ} \mathrm{C}$; UR: $70 \pm 10^{\circ}$; fotofase: 14 horas.

\begin{tabular}{|c|c|c|c|c|c|}
\hline \multirow[t]{2}{*}{ Instar } & \multicolumn{2}{|c|}{$\begin{array}{c}\text { Largura da cápsula cefá- } \\
\text { lica (mm) }\end{array}$} & \multirow[t]{2}{*}{$\begin{array}{l}\text { Duração }^{\left({ }^{*}\right)} \\
\text { (dias) }\end{array}$} & \multirow{2}{*}{\multicolumn{2}{|c|}{$\begin{array}{l}\text { Razão de } \\
\text { crescimento }\end{array}$}} \\
\hline & $\mathrm{I} \cdot \mathrm{V}^{(* *)}$ & média & & & \\
\hline 19 & $0,31-0,32$ & 0,31 & $5,5 \pm 0,76$ & & \\
\hline 29 & $0,42-0,46$ & 0,43 & $3,3 \pm 0,49$ & 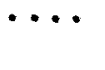 & 1,39 \\
\hline 30 & $0,60-0,75$ & 0,68 & $3,5 \pm 0,78$ & $\cdots$ & 1,51 \\
\hline 49 & $0,96-1,14$ & 1,04 & $4,5 \pm 0,53$ & $\cdots$ & 1,53 \\
\hline 50 & $1,22-1,63$ & 1,47 & $3,7 \pm 1,11$ & $\cdots$ & 1,41 \\
\hline 69 & $1,73-2,16$ & 1,79 & $6,1 \pm 1,86$ & $\cdots$ & 1,22 \\
\hline
\end{tabular}

(*) $70 \%$ das lagartas apresentaram 5 instares com duração média do 50 ins-

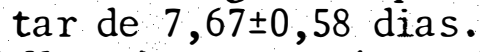

$(* *)$ I.V. = intervalo de variação. 
Tabela 40 - Largura média da cápsula cefálica, razão de crescimento e dura ção média de cada ínstar de 10 lagartas de $D$. saccharalis cria das em dieta artificjal utilizada na Usina Santa Bärbara. Temperatura: $25+$ PC; UR: $70 \pm 10 \%$; fotofase: 14 horas.

\begin{tabular}{|c|c|c|c|c|c|}
\hline \multirow{2}{*}{ Instar } & \multicolumn{2}{|c|}{$\underset{(\mathrm{mm})}{\text { Largura da cápsula cefálica }}$} & \multirow{2}{*}{$\begin{array}{c}\text { Duração }(*) \\
\text { (dias) }\end{array}$} & \multirow{2}{*}{\multicolumn{2}{|c|}{$\begin{array}{l}\text { Razão de } \\
\text { crescimen- } \\
\text { to }\end{array}$}} \\
\hline & I.V $(* *)$ & Média & & & \\
\hline 19 & $0,31-0,33$ & 0,31 & $4,8 \pm 0,79$ & & 130 \\
\hline $2 ?$ & $0,42-0,45$ & 0,43 & $3,3 \pm 0,48$ & & 1,09 \\
\hline $3 ?$ & $0,53-0,79$ & 0,65 & $3,0 \pm 0,82$ & & 155 \\
\hline $4 ?$ & $0,85-1,11$ & 1,00 & $3,8 \pm 0,79$ & $\cdots$ & 149 \\
\hline 50 & $1,40-1,59$ & 1,49 & $3,0 \pm 0,00$ & $\cdots$ & 102 \\
\hline $6 ?$ & $1,74-1,92$ & 1,82 & $5,7 \pm 2,31$ & & \\
\hline
\end{tabular}

Média da razão de crescimento 1,43

(*) $70 \%$ das lagartas apresentaram 5 ínstares com duração média do 50 in ins tar de 7,5 $\pm 0,84$ dias.

(**) I.V. = intervalo de variação. 
Tabela 41 - Largura média da cápsula cefálica, razão de crescimento e dura ção de cada instar de 10 lagartas de $D$. saccharalis criadas em dieta de feijão 'Carioca', germe de trigo e levedura (E). Temperatura: $25^{\circ} 1^{\circ} \mathrm{C}$; UR: $70 \pm 10 \%$; fotofase: 14 horas.

\begin{tabular}{|c|c|c|c|c|c|}
\hline \multirow{2}{*}{ Instar } & \multicolumn{2}{|c|}{$\begin{array}{c}\text { Largura da cápsula cefálica } \\
(\text { (mnn) }\end{array}$} & \multirow{2}{*}{$\begin{array}{l}\text { Duração }(*) \\
\quad \text { (dias) }\end{array}$} & \multirow{2}{*}{\multicolumn{2}{|c|}{$\begin{array}{c}\text { Razão de } \\
\text { crescimen- } \\
\text { to }\end{array}$}} \\
\hline & I.V. ${ }^{(* *)}$ & Média & & & \\
\hline 19 & $0,30-0,33$ & 0,32 & $3,7 \pm 0,483$ & & \\
\hline $2 ?$ & $0,41-0,47$ & 0,43 & $3,2 \pm 0,633$ & $\cdots$ & 1,34 \\
\hline 39 & $0,56-0,75$ & 0,66 & $3,4 \pm 0,699$ & $\cdots$ & 1,54 \\
\hline 49 & $0,83-1,18$ & 1,03 & $3,7 \pm 0,483$ & $\cdots$ & 1,55 \\
\hline 59 & $1,31-1,59$ & 1,45 & $4,2 \pm 0,753$ & $\cdots$ & \\
\hline 69 & $1,66-1,90$ & 1,72 & $6,3 \pm 1,708$ & $\cdots$ & 1,10 \\
\hline \multicolumn{3}{|c|}{ Mëdia da razão de crescimento } & & & 1,41 \\
\hline
\end{tabular}

(*) $60 \%$ das lagartas apresentaram 5 ínstares com duração média do 5 o instar de 7,83 0,75 dias.

(**) I.V. = intervalo de variação. 
Tabe1a 42 - Largura média da câpsula cefả1ica, razão de crescimento e dura ção de cada instar de 10 lagartas de $D$. saccharalis criadas em dieta artificial incluindo milho 'Nutrimaiz'. Temperatura: 25 10C; UR: $70 \pm 10 \%$; fotofase: 16 horas.

\begin{tabular}{|c|c|c|c|c|}
\hline \multirow{2}{*}{ Instar } & \multicolumn{2}{|c|}{ Largura da cápsula cefálica } & \multirow{2}{*}{$\begin{array}{l}\text { Duração (*) } \\
\text { (dias) }\end{array}$} & \multirow{2}{*}{$\begin{array}{l}\text { Razão de } \\
\text { crescimento }\end{array}$} \\
\hline & I.V. $(* *)$ & Mé dia & & \\
\hline 19 & $0,27-0,33$ & 0,30 & $3,3 \pm 0,82$ & 118 \\
\hline 29 & $0,42-0,47$ & 0,44 & $3,4 \pm 0,70$ & 1,40 \\
\hline 39 & $0,59-0,73$ & 0,68 & $3,7 \pm 0,67$ & 147 \\
\hline 49 & $0,85-1,10$ & 1,00 & $3,9 \pm 0,74$ & 1,43 \\
\hline 59 & $1,33-1,59$ & 1,43 & $5,0 \pm 1,07$ & 1,29 \\
\hline 69 & $1,69-1,96$ & 1,85 & $7,3 \pm 1,16$ & 1,29 \\
\hline
\end{tabular}

Média da razão de crescimento

1,44

(*) $20 \%$ das lagartas apresentaram 5 instares com duração média do 5 ? instar de $9,5 \pm 2,12$ dias.

(**) I.V. = intervalo de variação.

A razão de crescimento foi semelhante nas 4 die tas, sendo que o valor obtido na presente pesquisa, para a die ta padrão de HENSLEY e HAMMOND (1968) assemelhou-se ao valor de 1,43 registrado por MELO (1984). Os valores aqui conseguidos (Tabelas 39 a 42) para a razão de crescimento em cada uma das 4 dietas selecionadas, encontram-se inseridos no intervalo de 1,1 a 1,9 estabelecido por DYAR (1890). 
Tabela 43 - Porcentagem de lagartas de D. saccharalis que apresentaram 5 ou 6 instares, criadas em 4 dietas artificiais. Temperatura : $25 \pm 10 \mathrm{C}$; UR: $70 \pm 10 \%$; fotofase: 14 horas.

Dieta

5 instares $\left(\begin{array}{l}0 \\ 0\end{array}\right)$

6 instares ( $\left(\frac{0}{0}\right)$

$\begin{array}{lcc}\text { dieta E } & 60 & 40 \\ \text { milho 'Nutrimaiz' } & 20 & 80 \\ \text { Hensley e Hanmond } & 70 & 30 \\ \text { Usina Santa Bärbara } & 70 & 30\end{array}$

\subsubsection{Fase Pupal}

4.5.2.1. Peso

0 peso de pupas fêmeas, que è o parâmetro que tem maior importância em termos biolögicos, por estar intimamente relacionado à fecundidade, foi maior para aqueles insetos mantidos na dieta de HENSLEY e HAMMOND (1968), suplantando - peso daqueles provenientes das dieta de milho 'Nutrimaiz' e Usina Santa Bärbara, os quais foram semelhantes entre si. Para machos, os maiores pesos foram registrados nas pupas provenien tes do meio da Usina Santa Bärbara, sem diferir no entanto, da dieta com 'Nutrimaiz'. Os menores pesos de pupas, para ambos os 
sexos, foram obtidos na dieta E (à base de feijão 'Carioca', ger me de trigo e levedura) (Tabela 44).

Talela 44 - Peso médio das pupas (machos e fêmeas) de $D$. saccharalis criada em 4 dietas artificiais. Temperatura: $25 \pm 1{ }^{\circ} \mathrm{C}$; UR: $70 \pm$ $10 \%$; fotofase: '14 horas.

\begin{tabular}{ccccc}
\hline Dieta & Peso $(\mathrm{mg})$ & $\begin{array}{c}\text { I.V. }(* *) \\
0^{*}\left(*^{*}\right)\end{array}$ & $\begin{array}{c}\text { Peso }(\mathrm{mg}) \\
(\text { dias })\end{array}$ & $\begin{array}{c}\text { I.V. }(* *) \\
(\text { dias })\end{array}$ \\
\hline
\end{tabular}

Usina Santa Bärbara

$122,04 \pm 16,45$ a $80,0-160,0 \quad 173,00 \pm 29,28$ b $80,0-220,0$ milho 'Nutrimaiz' $118,89 \pm 17,69$ a b $80,0-160,0 \quad 180,00 \pm 20,53$ b 120,0-220,0 Hensley e Hamonond

dieta $\mathrm{E}$ $113,26 \pm 14,15$ b $\quad 80,0-150,0 \quad 195,64 \pm 28,65$ a $150,0-290,0$ $104,94 \pm 15,25$ c $\quad 70,0-130,0 \quad 160,50 \pm 26,70$ c $180,0-220,0$

${ }^{*}$ ) médias seguidas da mesma letra não diferem entre si, pelo teste de Tukey, ao nível de $5 \%$ de probabilidade.

(**)I.V. = intervalo de variação.

\subsubsection{Duração e viabilidade}

A duração do período pupal de fêmeas de $D$. saccharalis foi bastante próxima nas 4 dietas, sendo que para machos os menores valores foram obtidos na dieta de HENSLEY e HAMMOND (1968) (Tabela 45).

A viabilidade do período pupal foi maior na die ta de milho 'Nutrimaiz', sendo semethante ao valor encontrado 
na dieta de HENSLEY e HAMMOND (1968). O menor valor foi obtido naquele meio incluindo feijão 'Carioca', germe de trigo e leve dura (E) e este valor assemelhou-se ao da Usina Santa Bärbara $($ Tats? $a+5)$

4.5.3. Fase Adulta: longevidade, período de pré-oviposição, nümero de ovos por fêmea e porcentagem de deformação

A longevidade, tanto de machos como de fêmeas, da broca-da-cana foi semelhante nas 4 dietas selecionadas, não havendo, portanto, influência do meio neste parâmetro biológico (Tabela 46). A dieta de HENSLEY e HAMMOND (1968) deu origem ao maior número de adultos deformados, sendo a menor porcentagem observada na dieta de milho 'Nutrimaiz' (Tabela 46).

O major número de ovos foi obtido de fêmeas prọ venientes da dieta com milho 'Nutrimaiz' ( 866,9 ovos/fêmea), em bora este valor não tenha diferido daquele colocado por fêmeas oriundas da dieta de HENSLEY e HAMMOND (1968) (738,6 ovos/fêmea), que foi o meio que deu origem a fêmeas com menor capacidade de postura. O número de ovos, colocado por fêmeas provenientes dos 4 meios, foi muito superior aos valores registra dos na literatura (KING e.t alii, 1975; ARAUJO e.t alii, 1980; ME LO, 1984). O período de pré-oviposição não foi afetado pelos di ferentes meios utilizados (Tabela 47). 


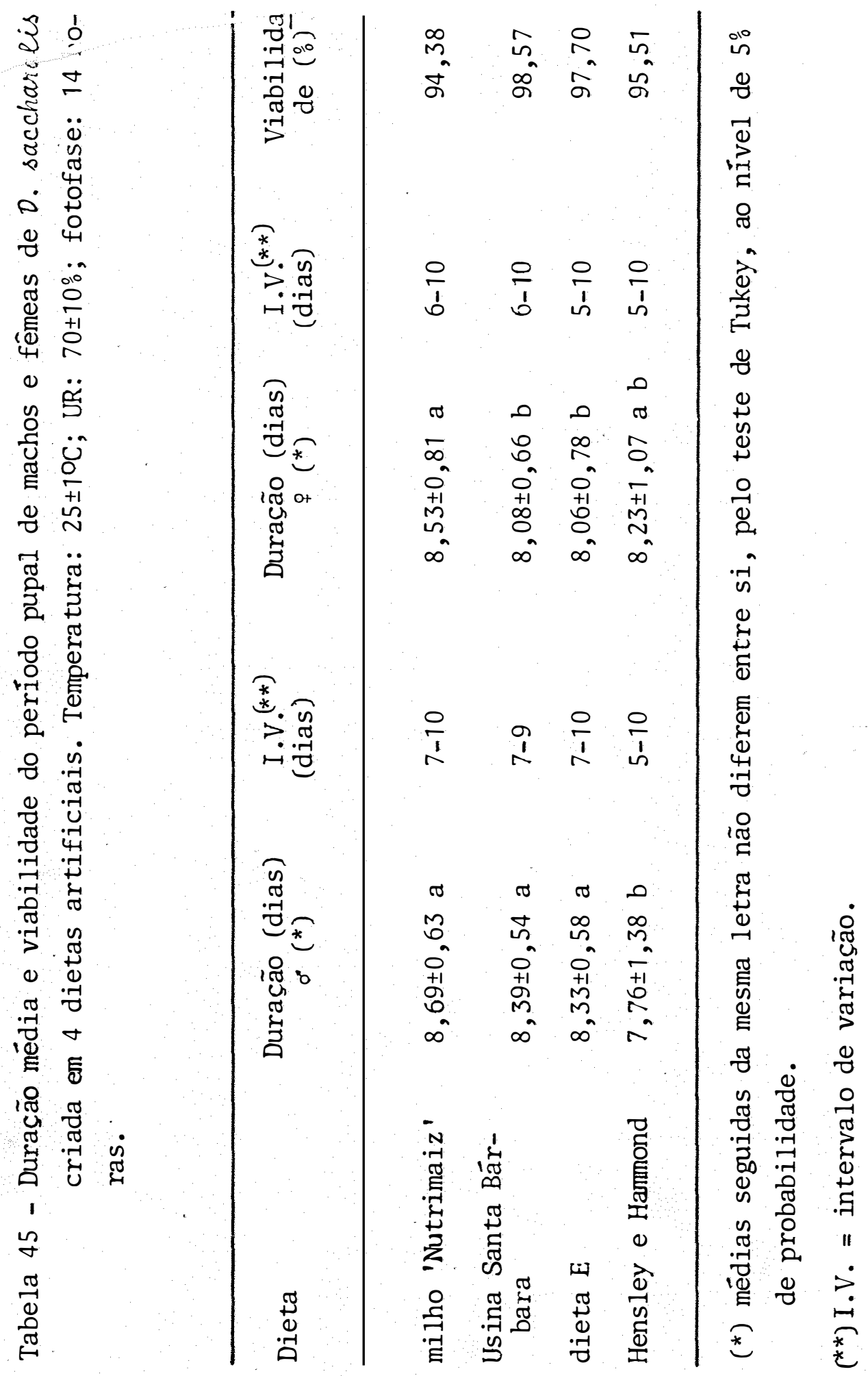


.88 .

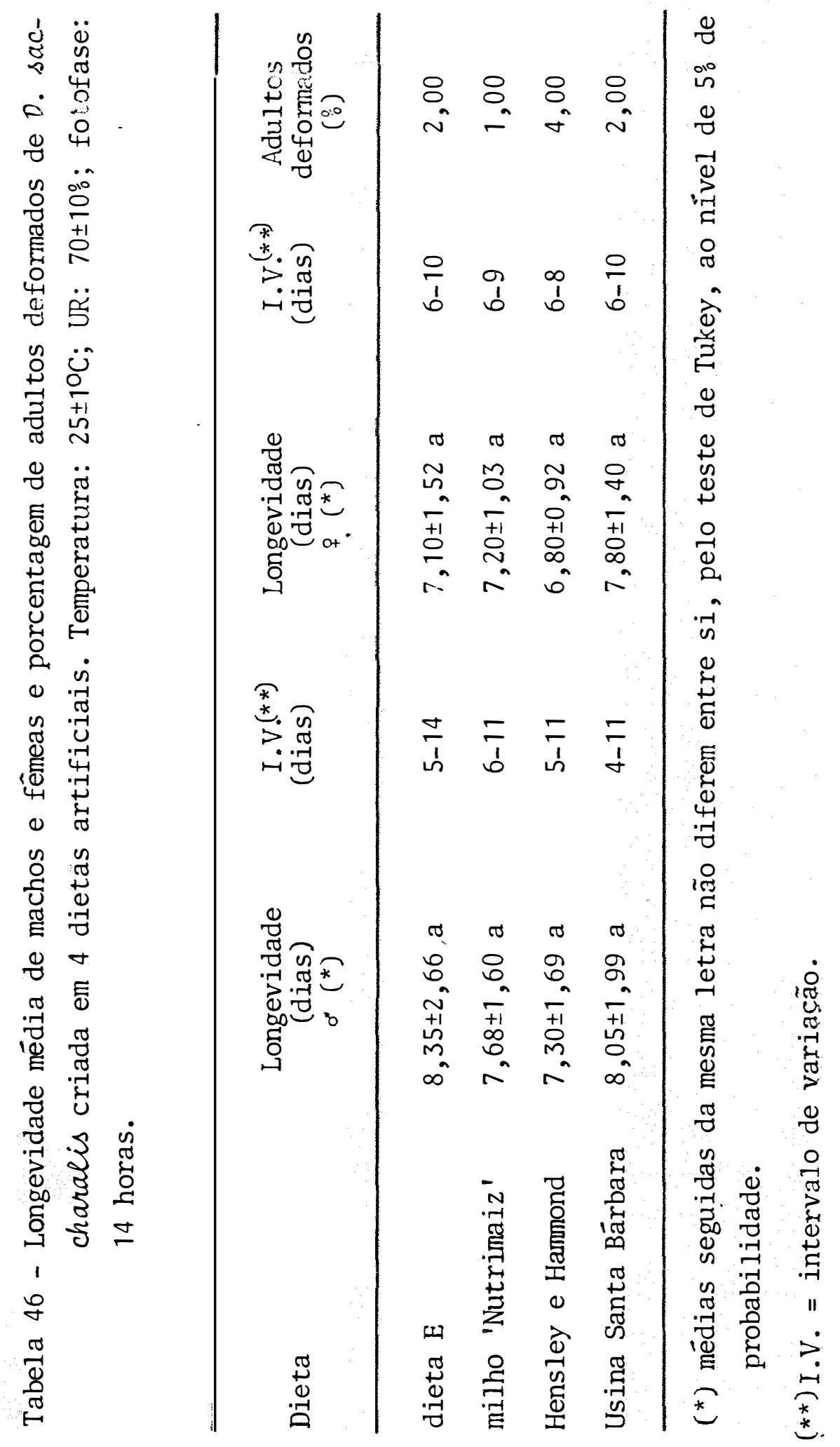


Tabela 47 - Período de prê-oviposição e total dos ovos por fêmea de D. sac charalis criada em 4 dietas artificiais. Temperatura: $25 \pm 10 \mathrm{C}$; UR: $70 \pm 10 \%$; fotofase: 14 horas.

\begin{tabular}{|c|c|c|c|}
\hline Dieta & $\begin{array}{c}\text { Pré-oviposi- } \\
\text { ção } \\
\text { (dias) }\end{array}$ & $\frac{\text { Total de ovos }}{\text { fêmea }}(*)$ & $I \cdot V(* *)$ \\
\hline dieta $E$ & $2,00 \pm 0,46$ & $749,8 \pm 92,79$ a & $616-916$ \\
\hline milho 'Nutrimaiz' & $2,00 \pm 0,00$ & $866,9 \pm 104,31 \mathrm{a}$ & $725-1055$ \\
\hline Hensley e Hammond & $2,00 \pm 0,00$ & $738,6 \pm 125,93$ a & $446-839$ \\
\hline Usina Santa Bärbara & $2,00 \pm 0,00$ & $766,2 \pm 128,47 \mathrm{a}$ & $551-933$ \\
\hline
\end{tabular}

(*) médias seguidas da mesma letra não diferem entre si, pelo teste de Tukey, ao nível de 5\% de probabilidade.

(**) I.V. = intervalo de variação.

A maior porcentagem de posturas ocorreu no primeiro dia (Fig. 3) para as fêmeas obtidas nas 4 dietas selecio nadas. Entretanto, observou-se que, para a dieta padrão de HENS LEY e HAMMOND (1968) e para aquela incluindo feijão 'Carioca', germe de trigo e levedura (E), houve apenas seis dias de postu ras, sendo que as fêmeas começaram a morrer a partir do 4 o dia. Deste modo, no 49, 59 e 69 dias de postura apenas oito, seis e uma fêmea para a $\uparrow$ ạ dieta e nove, quatro e uma fêmea para a 2 a dieta foram observadas, respectivamente. No 60 dia de postura, para ambas as dietas, a porcentagem de eclosão foi nula. Para a dieta da Usina Santa Bärbara e aquela de milho 'Nutrimaiz', as fêmeas delas provenientes apresentaram sete dias 


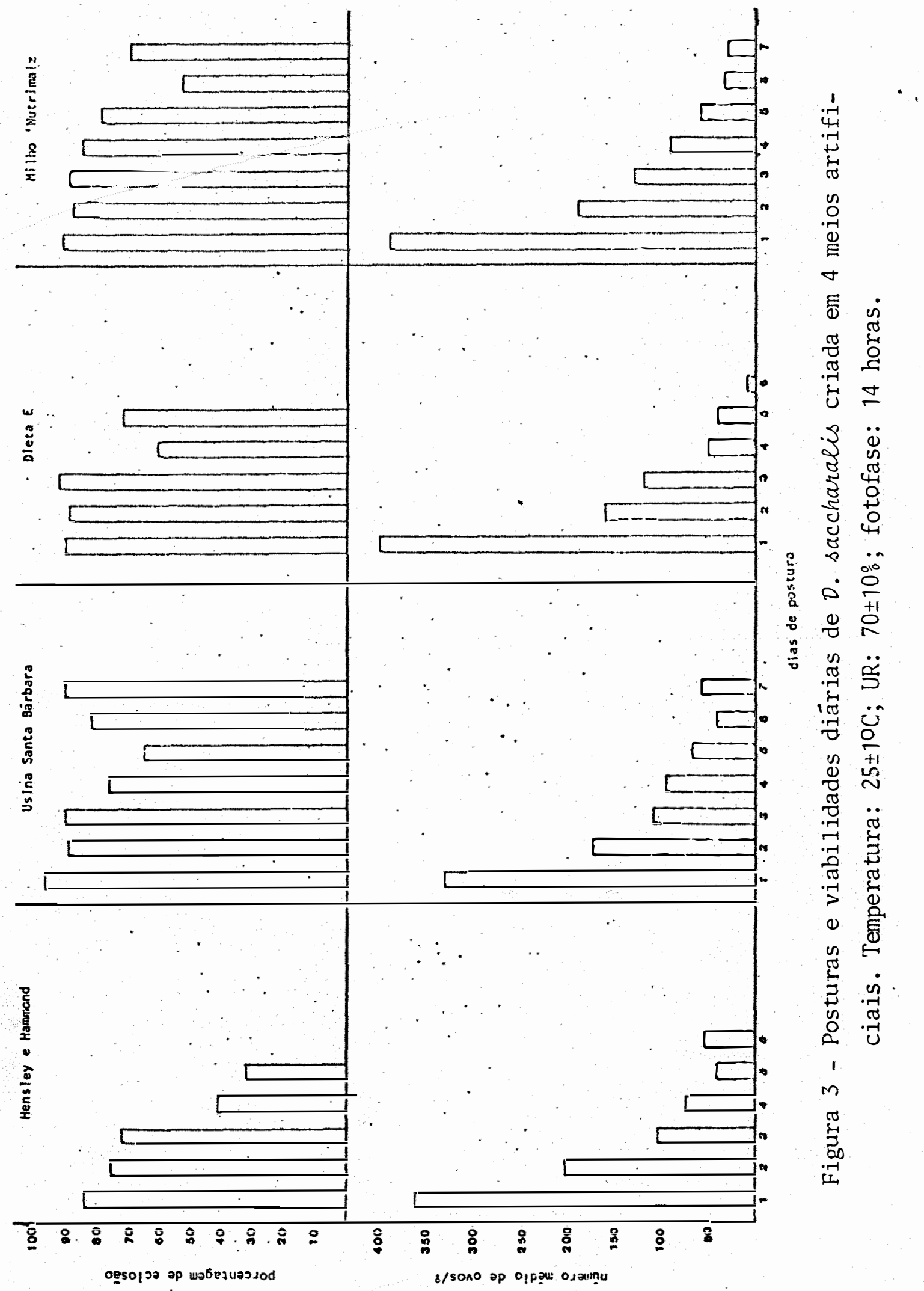


de postura e a mortalidade começou a partir do 5 o dia, sendo que nos 59,69 e 79 dias, observaram-se cinco, quatro e uma fêe mea para a lạ dieta e oito, quatro e duas fêmeas para a 2 ạ die ta, respectivamente. As posturas obtidas no 79 dia para as duas dietas, tivenim uma viabilidade elevada. Apesar desta diferença de comportamento, estatisticamente, não houve diferença entre a longevidade de fêmeas oriundas dos 4 meios testados (Tabela 46).

\subsubsection{Fase de Ovo: período de incubação e viabilidade}

A menor duração do período de incubação foi obtido na dieta padrão da Usina Santa Bärbara, embora este valor não tenha diferido daquele registrado na dieta incluindo feijão. 'Carioca', germe de trigo e levedura. Este valor, por sua vez, não diferiu daqueles obtidos para as dietas de HENSLEY e HAMMOND (1968) e da de milho 'Nutrimaiz'. As viabilidades foram elevadas em insetos criados em todos os meios (Tabela 48). 
Tabela 48 - Período de incubação e viabilidade dos ovos de 0 . saccharalis criada em 4 dietas artificiais. Temperatura: $25 \pm 1{ }^{\circ} \mathrm{C}$; UR: $70 \pm$ $10 \%$; fotofase: 14 horas.

Dieta

Período de incu-

bação (dias) (*)

I.V.(**) Viabilidade

(dias)

dos ovos

$\left(\begin{array}{l}0 \\ 0\end{array}\right)$

dieta $\mathrm{E}$

$6,41 \pm 0,51$ a b

$5-10$

88,82

milho 'Nutrimaiz'

$6,66 \pm 0,45$ a

$5-8$

87,00

Hensley e Hammond

$6,74 \pm 0,46$ a

$6-10$

83,00

Usina Santa Bärbara

$6,08 \pm 0,28 \mathrm{~b}$

5-8

87,46

(*) médias seguidas da mesma letra não diferem entre si, pelo teste de Tukey, ao nível de 5\% de probabilidade.

(**) I.V. = intervalo de variação.

\subsubsection{Efeito Fagoestimulante e Viabilidade Total}

O efeito fagoestimulante das dietas sobre as la gartas recém-eclodidas da broca-da-cana foi elevado. A dieta de milho 'Nutrimaiz' apresentou o valor mais elevado, enquanto que na dieta padrão da Usina Santa Bárbara registrou-se o menor"pegamento inicial" (Tabela 49).

Analisando-se os parâmetros biológicos estudados, nota-se que a dieta de milho. 'Nutrimaiz' foi a que apresentou a maior viabilidade total, nenhuma contaminação por fun 
gos, reduzida porcentagem de adultos deformados e a maior capa cidade média de postura. Fixando-se o valor de $75 \%$ de viabilidade total como o nivel para que uma dieta artificial possa ser utilifrea (SINGH, 1983), a dieta de milho 'Nutrimaiz' poderia ser considerada a mais adequada para a criação da broca-da-cana, pois aquelas tomadas como padrão, especialmente a de HENS LEY e HAMMOND (1968), estiveram aquém deste valor (Tabela 49). Ficou patenteada a importância do milho nesta dieta, pois os componentes da dieta $\mathrm{E}$ são os mesmos desta dieta, apenas com substituição do milho pela feijão e todavia foram obtidos resul tados inferiores.

Tabela 49 - Efeito fagoestimulante ("pegamento inicial") e viabilida de total de $D$. saccharalis criada em 4 dietas artificiais. Tem peratura: $25 \pm 10^{\circ} \mathrm{C}$; UR: $70 \pm 10^{\circ}$; fotofase: 14 horas.

Dieta

Efeito fagoestimulante

$\left(\begin{array}{l}0 \\ 0\end{array}\right)$
Viabilidade total

$\left(\begin{array}{l}\% \\ 0\end{array}\right)$

$\begin{array}{lll}\text { dieta E } & 95,00 & 74,61 \\ \text { milho 'Nutrimai.z' } & 98,00 & 79,75 \\ \text { Hensley e Hanmond } & 95,00 & 70,55 \\ \text { Usina Santa Bärbara } & 93,00 & 74,34\end{array}$




\subsubsection{Tabe1a de Vida de Fertilidade}

As tabelas de vida de $D$. saccharalis criada nas 4 dietas selecionadas são anxesentadas nas Tabelas 50 a 53.

Observou-se que a taxa líquida de reprodução (Ro) foi maior na dieta de milho 'Nutrimaiz', obtendo-se um aumento da população de 338,38 vezes a cada geração. Os valores encontrados nas demais dietas foram menores e semelhantes entre si. Na dieta de HENSLEY e HAMMOND (1968) foi obtido o menor valor $(261,88)$ sendo, no entanto, superior ao registrado por MÉLO (1984) .

0 menor período para completar uma geração

foi encontrado na dieta de HENSLEY e HAMMOND (1968), sendo este valor de 41,19 dias, bastante inferior aos 57,90 dias encon trados por MELO (1984). O maior período foi observado na dieta de fei jão 'Carioca', germe de trigo e levedura. As dietas de milho 'Nutrimaiz' e da Usina Santa Bárbara anresentaram valores intermediários de duração de uma geração.

A capacidade de aumentar em nümero $\left(\mathrm{r}_{\mathrm{m}}\right)$ foi menor na dieta de feijão 'Carioca', germe de trigo e levedura (E) apresentando valores semelhantes e superiores para as demais dietas. A razão finita de aumento ( $\lambda$ ) foi próxima nas die tas tomadas como padrão e na de milho 'Nutrimaiz', sendo menor na dieta de feijão 'Carioca', germe de trigo e levedura. 
Tabela 50 - Tabela de vida de fertilidade para D. saccharalis mantida em dieta artificial à base de feijão 'Carioca', germe de trigo e levedura. Temperatura: $25 \pm 1{ }^{\circ} \mathrm{C}$; UR: $70 \pm 10 \%$; fotofase: 14 horas.

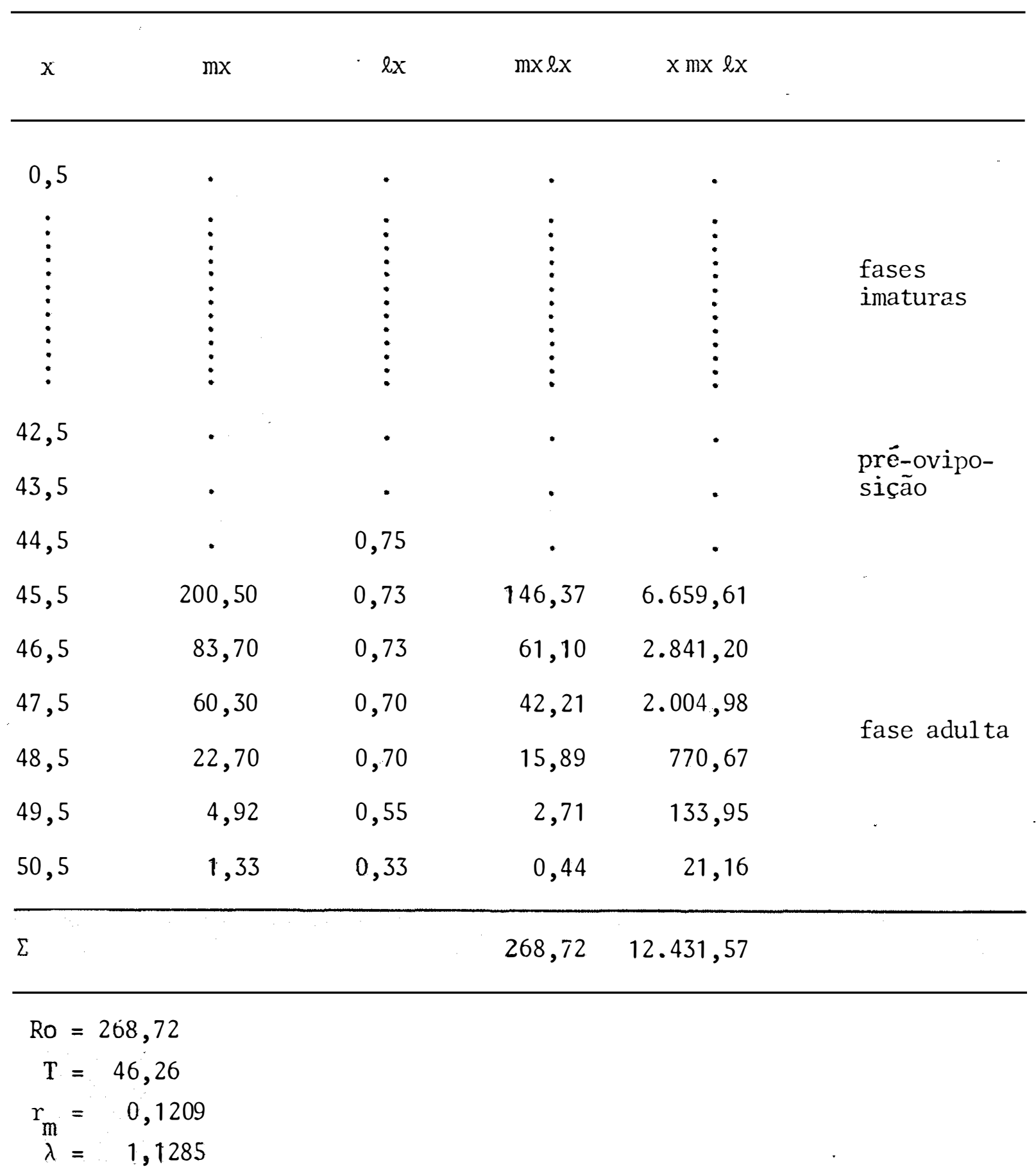


Tabela 51 - Tabela de vida de fertilidade para D. saccharalis mantida em dieta artificial de milho 'Nutrimaiz'. Temperatura: $25 \pm 1^{\circ} \mathrm{C}$; UR: $70 \pm 10 \%$; fotofase: 14 horas.

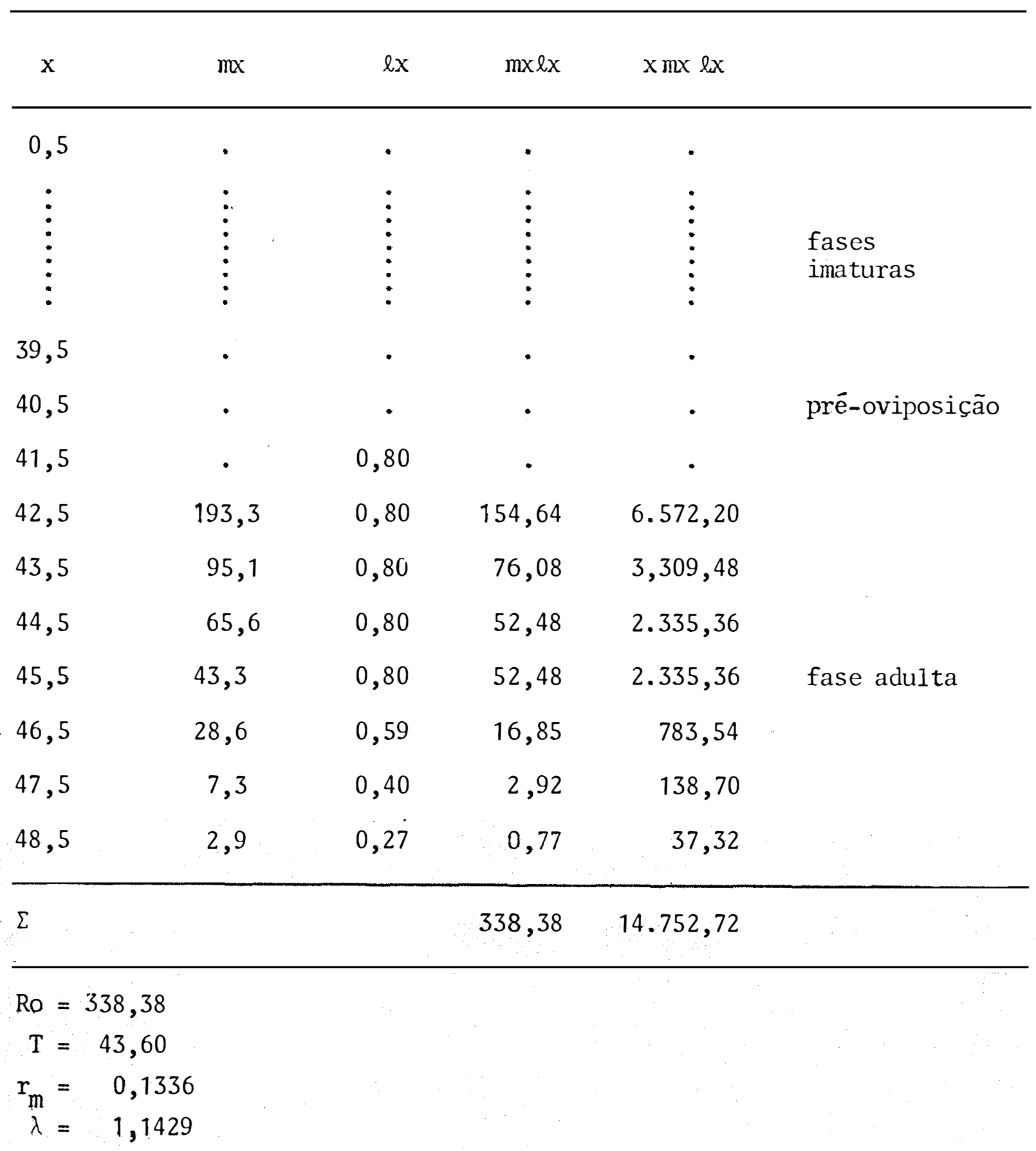


Tabela 52 - Tabela de vida de fertilidade para D. saccharalis mantida em dieta artificial de HENSLEY e HAMMOND (1968). Temperatura: 25 10C; UK: $70 \pm 10 \%$; fotofase: 14 horas.

\begin{tabular}{|c|c|c|c|c|c|}
\hline$x$ & $\mathrm{mx}$ & $\ell x$ & $\operatorname{mxlx}$ & $x \operatorname{mx} l x$ & \\
\hline 0,5 & - & - & - & - & \multirow[b]{2}{*}{ fases imaturas } \\
\hline$\vdots$ & $\vdots$ & $:$ & $\vdots$ & $\vdots$ & \\
\hline 37,5 & - & 0,71 & - & • & \multirow{2}{*}{ prē-oviposiçāo } \\
\hline 38,5 & - & 0,71 & - & - & \\
\hline 39,5 & 180,8 & 0,71 & 128,37 & $5.070,54$ & \multirow{6}{*}{ fase adulta } \\
\hline 40,5 & 103,8 & 0,71 & 73,70 & $2.985,77$ & \\
\hline 41,5 & 50,8 & 0,69 & 30,05 & $1.454,66$ & \\
\hline 42,5 & 29,3 & 0,66 & 19,31 & 820,46 & \\
\hline 43,5 & 17,1 & 0,45 & 7,71 & 335,52 & \\
\hline 44,5 & 8,8 & 0,31 & 2,74 & 121,81 & \\
\hline$\Sigma$ & & & 261,88 & $10.787,76$ & \\
\hline
\end{tabular}

$$
\begin{aligned}
\mathrm{Ro} & =261,88 \\
\mathrm{~T} & =41,19 \\
\mathrm{rm} & =0,1352 \\
\lambda & =1,1448
\end{aligned}
$$


Tabela 53 - Tabela de vida de fertilidade para $D$. saccharalis mantida em dieta artificial da Usina Santa Bärbara. Temperatura: $25 \pm 1^{\circ} \mathrm{C}$; UR: $70 \pm 10 \%$; fotofase: 14 horas.

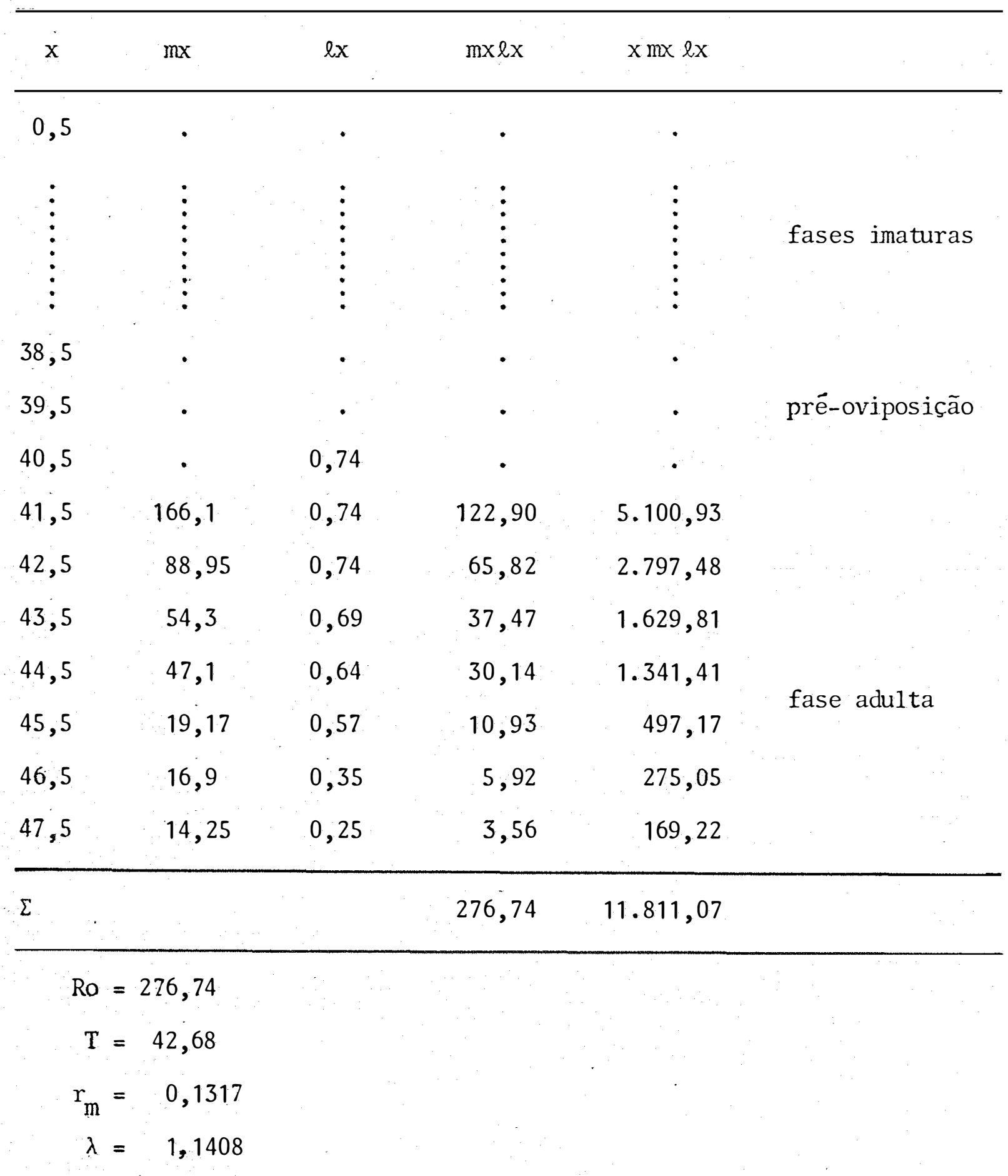




\subsubsection{Consumo e Utilização do Alimento nas 4 Dietas} Selecionadas

Os resultados obtidos em relação aos diferentes parâmetros nutricionais, calculados para as 4 dietas seleciona das, são apresentados na Tabela 54.

A quantidade de alimento consumido (AC) foi semelhante nas 4 dietas pesquisadas. Por sua vez, o ganho de peso de lagartas, no máximo desenvolvimento, foi maior na dieta contendo milho 'Nutrimaiz'. Deste modo, observa-se que o ganho de peso não está diretamente associado a quantidade de alimento consumido, indicando a alimentação diferencial do inseto, de pendendo do meio (Tabela 54).

A digestibilidade aproximada (AD) foi maior na dieta padrão de HENSLEY e HAMMOND (1968) e menor naquela incluindo feijão 'Carioca', germe de trigo e levedura, a qual não diferiu, entretanto, do valor obtido para a de milho 'Nutrimaiz'. A dieta da Usina Santa Bárbara apresentou um valor intermediário (Tabela 54). A eficiência de conversão do alimen to ingerido (ECI) foi maior no substrato com milho 'Nutrimaiz', sendo semelhante nos demais. Para a eficiência de conversão do alimento digerido (ECD), destacou-se, novamente, a de milho 'Nutrimaix'. Portanto, dos índices preconizados por WALDBAUER (1968) e utilizados com sucesso para a comparação de dietas artificiais por vários autores, inclusive para D. saccharalis (BREWER, 1981), as eficiências de conversão do alimento ingerido e digerido fo 
.100 .

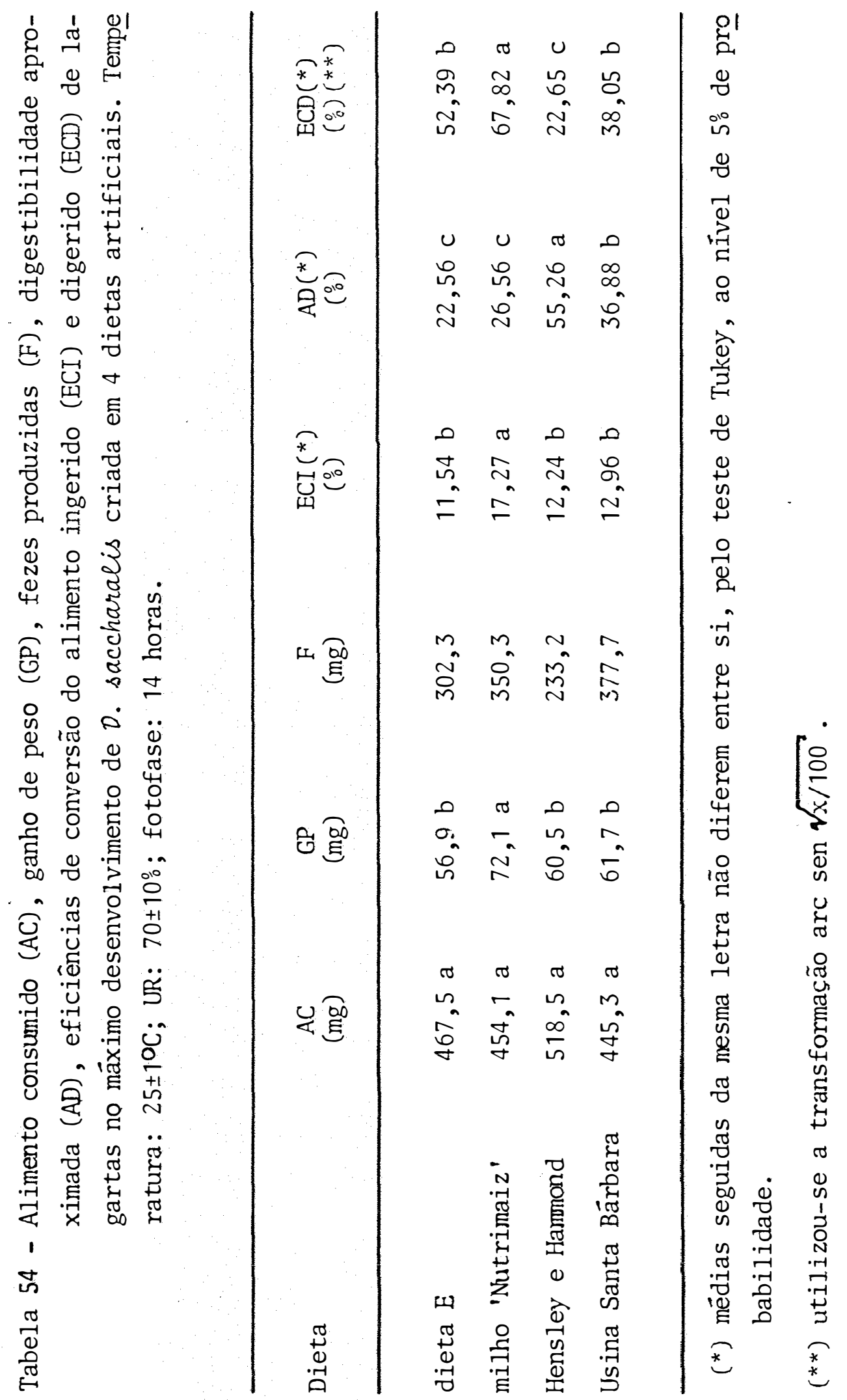


ram maiores na dieta de milho 'Nutrimaiz', indicando sua maior eficiência nutricional para a broca-da-cana.

\subsubsection{Anảlise de Proteína}

\subsubsection{Método de Kjedahl}

As porcentagens de proteina nas 4 dietas selecionadas e em lagartas no máximo desenvolvimento, criadas nestes meios selecionados, são apresentadas na Tabela 55.

A porcentagem de proteína total foi menor na dieta de milho. 'Nutrimaiz', sendo semelhante nas três outras. O valor encontrado na dieta de HENSLEY e HAMMOND (1968) foi de $24,14 \%$, assemelhando-se àquele de $24,0 \%$ relatado por MARTINS (1983). Os teores de proteínas em lagartas no máximo desenvolvimento foram semelhantes indicando que, apesar das diferentes porcentagens protéicas das dietas, houve diferenças na capacidade de conversão pelo inseto (Tabela 55).

Pelo valor da taxa de eficiência protéica (PER) constatou-se que a dieta de milho 'Nutrimaiz' foi a mais apropriada para a criação da broca-da-cana, pois, a despeito de a-

presentar uma baixa porcentagem de proteínas, a eficiência de conversão pelas lagartas foi muito elevada neste meio, possi- 
velmente, pela maior disponibilidade das proteinas presentes pa ra o desenvolvimento do inseto, em relação as outras dietas (Tabela 56).

Tabela 55 - Porcentagens de proteína total em lagartas de $D$. saccharalis no máximo desenvolvimento e das 4 dietas utilizadas para a sua criação. Temperatura: $25 \pm 1^{\circ} \mathrm{C}$; UR: $70 \pm 10 \%$; fotofase: 14 horas.

Dieta

Proteína Total $\left(\begin{array}{c}0 \\ 0\end{array}\right)$

Dieta Lagarta

dieta $\mathrm{E}$

23,89

46,64

milho 'Nutrimaiz'

17,88

43,08

Hensley e Harmnond

24,14

45,69

Usina Santa Bārbara

26,95

43,19

Tabela 56 - Taxa de eficiência protéica (PER) de lagartas de D. saccharalis, no máximo desenvolvimento, criadas em 4 dietas artificiais, Temperatura: $25 \pm 1{ }^{\circ} \mathrm{C}$; UR: $70 \pm 10^{\circ}$; fotofase: 14 horas.

\begin{tabular}{lc}
\hline Dieta & PER \\
\hline dieta E & 0,5071 \\
milho 'Nutrimaiz' & 0,8821 \\
Hensley e Hammond & 0,4862 \\
Usina Santa Bärbara & 0,5132 \\
\hline
\end{tabular}




\subsubsection{Eletroforese}

Através da análise eletroforética, esquemàtizou-se o eletrofoterograma das 4 dietas selecionadas (Fig. 4). Não se pode afjrmar que todas as proteinas incluidas nas dietas e que influem no seu desempenho, tenham sido detectadas, devido às próprias limitações do método utilizado para esta fi nalidade.

Observou-se que a dieta de HENSLEY e HAMMOND (1968) apresentou o maior nümero de bandas protéicas (13), o que se justifica pela sua composição, provavelmente, superestí mada, devido a maior quantidade de componentes utilizados. A dieta de feijão 'Carioca', germe de trigo e levedura apresentou 12 bandas, enquanto a de 'milho 'Nutrimaiz' e da Usina San ta Bärbara apresentaram 11 e 9 bandas, respectivamente. Não hou ve, portanto, correspondência entre a presença de bandas e dis ponibilidade para o inseto. 

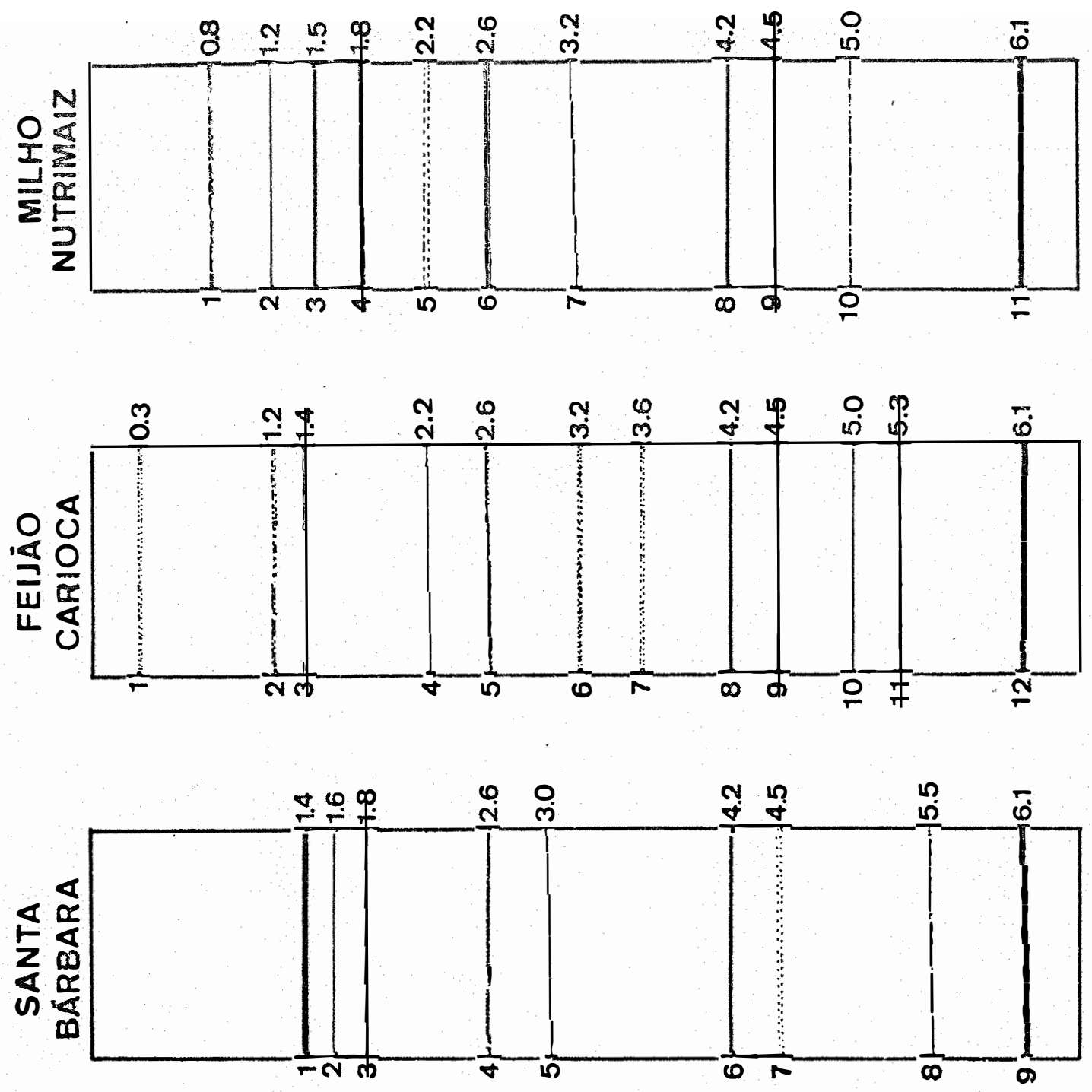

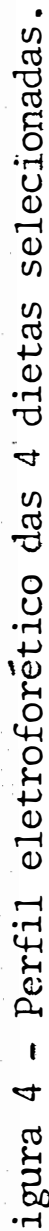

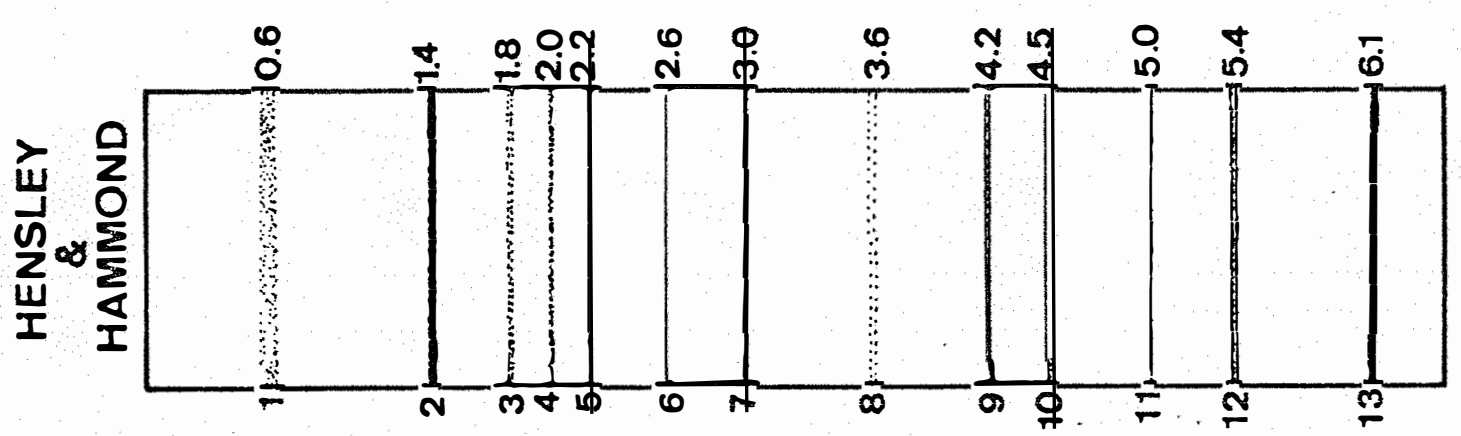




\subsubsection{Custø das 4 Dietas Selecionadas}

Os resultados de custo das dietas são apresentados, em Cr\$, nas Tabelas 57 a 60 .

Tabela 57 - Composição e custo de $1000 \mathrm{~g}$ da dieta de HENSLEY e HAMMOND (1968).

\begin{tabular}{lrc}
\hline Componentes & Quantidade & Preço (Cr $\$)$ \\
\hline tetraciclina & $1,0 \mathrm{~g}$ & 106,20 \\
sais de Wesson & $36,0 \mathrm{~g}$ & 1152,00 \\
caseína & $108,0 \mathrm{~g}$ & 4968,00 \\
sacarose & $180,0 \mathrm{~g}$ & 279,00 \\
germe de trigo & $108,0 \mathrm{~g}$ & 289,00 \\
cloreto de colina & $3,6 \mathrm{~g}$ & 475,20 \\
solução vitamínica & $36,0 \mathrm{ml}$ & 417,60 \\
ácido ascórbico & $14,4 \mathrm{~g}$ & 1512,00 \\
formaldeído (37,2\%) & $1,8 \mathrm{ml}$ & 22,00 \\
metil p-hidroxibenzoato (nipagin) & $5,4 \mathrm{~g}$ & 426,00 \\
ägar & $720 \mathrm{~g}$ & 5688,00 \\
água & $3116,0 \mathrm{ml}$ & - \\
\hline Total & $3682,2 \mathrm{~g}$ & 15696,30 \\
\hline & $1000,0 \mathrm{~g}$ & 269,39 \\
\hline
\end{tabular}


Tabela 58 - Composição e custo de $1000 \mathrm{~g}$ da dieta utilizada na Usina Santa Bärbara.

\begin{tabular}{lcc}
\hline Componentes & nuantidade & Preço (Cr\$) \\
\hline germe de trigo & $54,0 \mathrm{~g}$ & 129,60 \\
caseína & $54,0 \mathrm{~g}$ & 2484,00 \\
sacarose & $90,0 \mathrm{~g}$ & 139,50 \\
sais de Wesson & $18,0 \mathrm{~g}$ & 756,00 \\
ácido ascórbico & $7,2 \mathrm{~g}$ & 1890,00 \\
metil p-hidroxibenzoato (nipagin) & $2,7 \mathrm{~g}$ & 213,30 \\
cloreto de colina & $1,8 \mathrm{~g}$ & 64,80 \\
tetraciclina & $1,0 \mathrm{~g}$ & 102,60 \\
formaldeído (37,2\%) & $2,0 \mathrm{ml}$ & 25,00 \\
solução vitamínica & $20,0 \mathrm{ml}$ & 232,00 \\
ácido acético & $2,0 \mathrm{ml}$ & 37,00 \\
ágar & $36,0 \mathrm{~g}$ & 2844,00 \\
água & $1450,0 \mathrm{ml}$ & - \\
\hline Total & $1738,7 \mathrm{~g}$ & 5136,65 \\
\hline
\end{tabular}


Tabela 59 - Composição e custo de 1000 g da dieta com milho 'Nutrimaiz'.

\begin{tabular}{lcc}
\hline Componentes & Quantidade & Preço (Cr\$) \\
\hline farinha de milho & $28,00 \mathrm{~g}$ & 39,67 \\
levedura de cerveja & $7,50 \mathrm{~g}$ & 33,75 \\
germe de trigo & $7,00 \mathrm{~g}$ & 16,80 \\
ácido ascórbico & $1,00 \mathrm{~g}$ & 105,00 \\
ácido benzöico & $0,25 \mathrm{~g}$ & 12,15 \\
metil p-hidroxibenzoato (nipagin) & $0,20 \mathrm{~g}$ & 15,80 \\
ágar & $5,00 \mathrm{~g}$ & 395,00 \\
água & - & - \\
\hline Total & $248,95 \mathrm{~g}$ & 618,17 \\
\hline
\end{tabular}


Tabela 60 - Composição e custo de $1000 \mathrm{~g}$ da dieta com feijão 'Carioca', gẹ me de trigo e levedura.

\begin{tabular}{lrc}
\hline Componentes & Quantidade & Preço (Cr\$)' \\
\hline gemne de trigo & $40,00 \mathrm{~g}$ & 96,00 \\
feijão 'Carioca' & $173,00 \mathrm{~g}$ & 295,50 \\
ácido ascórbico & $2,60 \mathrm{~g}$ & 273,00 \\
levedura de cerveja & $25,50 \mathrm{~g}$ & 114,75 \\
metil p-hidroxibenzoato (nipagin) & $1,60 \mathrm{~g}$ & 126,40 \\
ácido ascórbico & $0,80 \mathrm{~g}$ & 60,00 \\
formaldeído (37,2\%) & $0,65 \mathrm{ml}, 13$ \\
ágar & $10,20 \mathrm{~g}$ & 805,80 \\
água & $611,00 \mathrm{ml}$ & - \\
\hline Total & $865,35 \mathrm{~g}$ & 1779,88 \\
\hline
\end{tabular}

Pelos cálculos de custo realizado (Tabela 61) pô de-se constatar que, um dos meios mais econômicos para a criação de $D$. saccharalis é aquele com milho 'Nutrimaiz'. Portanto, aliado ao excelente resultado biológico obtido neste meio, este custo de 2,69 e 2,54 vezes menor do que aquele obtido, respectivamente, nas dietas de HENSLEY e HAMMOND (1968) e da Usina Santa Bárbara, o credencia a ser um substituto, com vanta- 
gens, das dietas normalmente utilizadas no rasil para a criação da broca-da-cana.

Tabela 61 - Custo da dieta (ORIN) para a produção de 10.000 lagartas de D. saccharalis em 4 meios artificiais. Temperatura: $25 \pm 1{ }^{\circ} \mathrm{C}$; UR: $70 \pm 10 \%$; fotofase: 14 horas.

\begin{tabular}{|c|c|c|c|c|}
\hline Dieta & $\begin{array}{l}\text { Consumo da } \\
\text { lagarta } \\
\text { (mg) }\end{array}$ & Perda d 'agua & $\begin{array}{c}\text { Viabilidade } \\
\text { larval } \\
\left(\begin{array}{l}0 \\
0\end{array}\right)\end{array}$ & $\begin{array}{c}\text { Preço da dieta } \\
\text { (ORTN) } \\
(10000 \\
\text { lagartas) }\end{array}$ \\
\hline dieta $E$ & 467,5 & 81 & 89 & 2,08 \\
\hline milho 'Nutrimaiz' & 454,1 & 82 & 93 & 2,45 \\
\hline Hensley e Hanmond & 518,5 & 86 & 87 & 6,60 \\
\hline $\begin{array}{l}\text { Usina Santa Bár- } \\
\text { bara }\end{array}$ & 445,3 & 85 & 89 & 6,23 \\
\hline
\end{tabular}

\subsubsection{Análise de Agrupamento}

Pelo fenograma (Fig. 5) evidenciou-se a presenca de 2 grupos distintos: um formado pelas dietas tomadas como padrão e aquela de feijão 'Carioca', germe de trigo e levedura e outro pela dieta com milho 'Nutrimaiz', respectivamente, aos níveis de semelhança adotados de 0,500 e 0,545 .

Complementando a técnica para avaliação da simi laridade entre as 4 dietas selecionadas, a análise dos compo- 
nentes principais confirmou a pré-suposição da existência de 2 grupos distintos mostrados no gräfico tridimensional da Figu ra 6 .

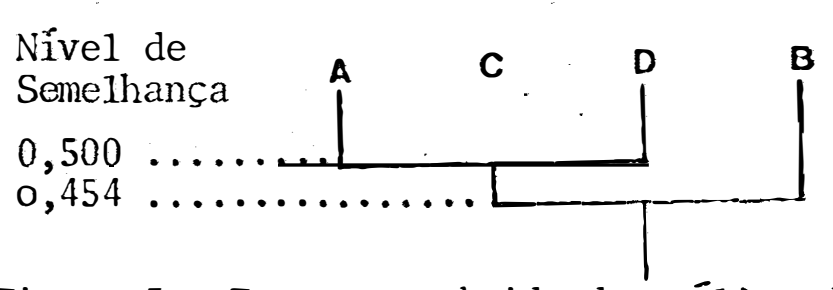

A: feijão 'Carioca' e germe de Nivel de Semelhança trigo

Figura 5 - Fenograma obtido da análise de agrupamento de 4 dietas artificiais, em função de seus parâmetros biológicos e nutricionais.
A: $(-0,8 ;-2,7 ;+7,3)$
B: $(+4,3 ;+1,7 ;+5,6)$
C: $(-3,5 ;+2,6 ;+5,1)$
D: $(0,0 ;-1,6 ;+2,1)$

C: Hensley e Hammond

D: Usina Santa Bárbara

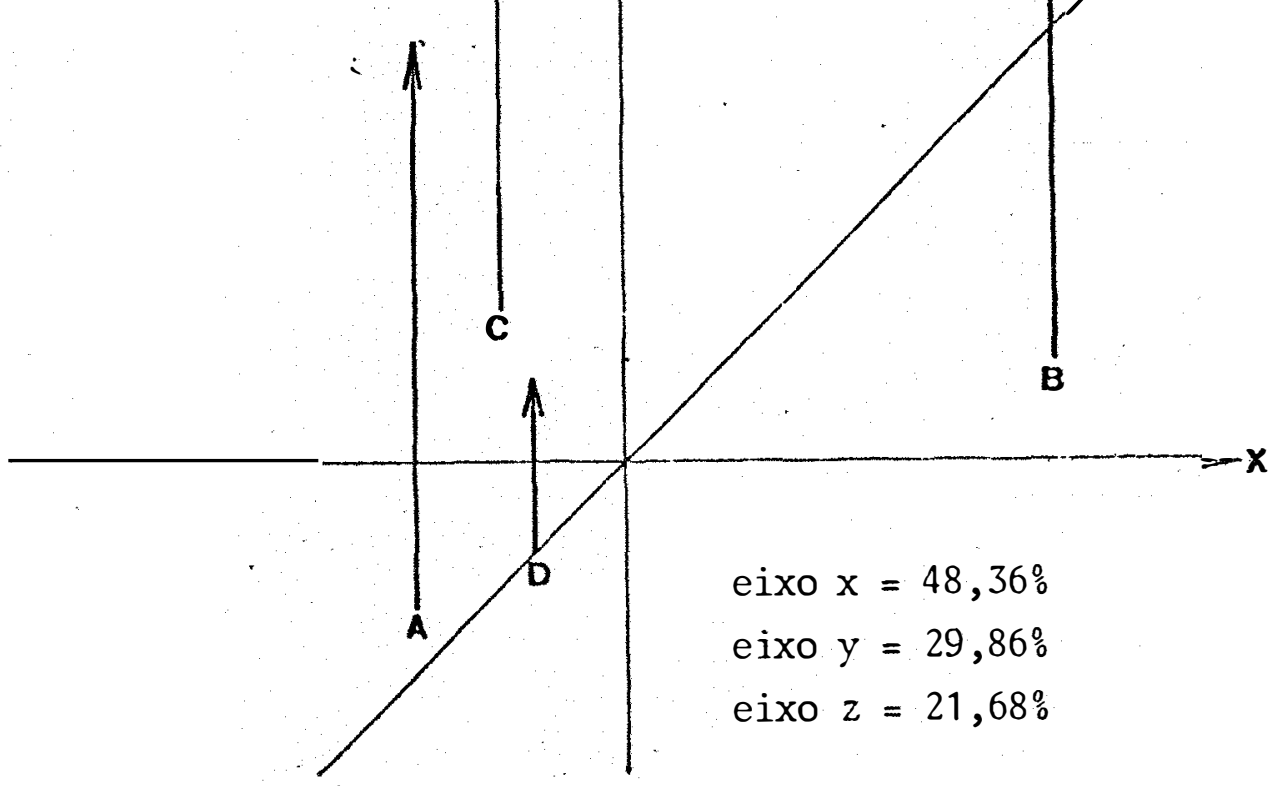

Figura 6 - Diagrama tridimensional comparativo das 4 dietas selecionadas, em função dos seus parämetros biológicos e nutricionais, pelo método de análise dos componentes principais. 
.111.

\section{CONCLUSÃO}

Baseando-se nos resultados obtidos, conclui-. -se que a dieta à base de milho 'Nutrimaiz' pode substituir, com vantagens, dietas normalmente utilizadas para criações de laboratório de Diatraea saccharalis (Fabricius, 1794). 


\section{LITERATURA CITADA}

ARAUJO, J.R.; S.M.S. ARAUJO; P.S.M. BOTELHO e N. DEGASPARI, 1980. Obtenção de posturas de Diatraea saccharalis em condições de laboratório. Brasil Açucareiro. Rio de Janeiro, 97(3): 67-73.

BATAGLIA, O.C.; J.P.F. TEIXEIRA; A.M.C. FURLANI e J.R. GALLO, 1978. Métodos de análise cuímica de plantas. Campinas, Instituto Agronômico. 31p. (Circular nọ 87).

BERGER, R.S., 1963. Laboratory techiniques for rearing Heliothis spp. on artificial medium. A.R.S., United State Department of Agriculture. Washington, 33-84, 4p. 
BOWLING, C.C., 1967. Rearing of two lepidopterous pests of rice on a common artificial diet. Annals of the Entomological Society of America: Columbus, 60(6): 1215$-1216$.

BREWER, F.D., 1976. Development of the sugarcane borer on various artificial diets. A.R.S., United State Department of Agriculture. Washington, 116: 1-6.

BREWER, F.D., 1977a. Alternate protein sources and supplemental B-vitamin requeriments in rearing the sugarcane borer on a wheat germ diet. Journal of the Georgia Entomological Society. Athens, 12(4): 283-291.

BREWER, F.D., 1977b. Development of Heliothis zea and Diatraea saccharalis on a flash sterilized soyflour-wheat germ diet. Journal of the Georgia Entomological Society. Athens, 12(2): $154-157$.

BREWER, F.D., 1981. Development of Heliothis virescens and Diatraea saccharalis on a soyflour-corn oil diet. Annals of the Entomological Society of America: Columbus, 74(3): 320-323.

BUTT, B.A. e E. CANTU, 1962. Sex determination of lepidopterous pupae. A.R.S., United State Department of Agriculture. Washington, no 33-75, 7n. 
BREWER, J.M. e R.B. ASHWORTH, 1969. Disc electrophoresis. Journal of Chemical Education. Eastern, 46: 41-45.

DYAR, H.G., 1980. The number of molts of lepidopterous larvae. Psyche. Massachussets, $\underline{5}: 420-422$.

GALLO, D.; F.M. WIENDL; R.N. WILLIAMS e E. BERTI FILHO, 1969. Método de criação artificial da broca da cana-de-açúcar para emprego no seu controle. In: II Reunião Anual da Sociedade Entomológica do Brasil. Recife, 4p. [Resumos] .

HENSLEY, S.D. A A.H. HAMMOND, 1968. Laboratory techniques for rearing the sugarcane borer on an artificial diet. Journal of Economic Entomology. Geneva, 61(6): 1742-1743.

KASTEN, Jr., P.; A.A.C.M. PRECETTI e J.R.P. PARRA, 1978. Dados biológicos comparativos de spodoptera frugiperda (J.E. Smith, 1797) em duas dietas artificiais e substrato natural. Revista da Agricultura. Piracicaba, 53(1-2): 67-78.

KING, E.G.; F.D. BREWER e D.F. MARTIN, 1975. Development of Diatraea saccharalis (Lep.: Pyralidae) at constant temperatures. Entomophaga. Paris, 20 (3): 301-306. 
KOGAN, M., 1980. Bases nutricionais e aplicações em programas de manejo de pragas. In: Anais do VI Congresso Brasileiro de Entomologia. Campinas, 45-76.

MACEDO, N.; P.S.M. BOTElHO; N. DEgASPARI; L.C. AlMEIDA; J.R. ARAUJJO e E.A. MAGRINI, 1983. Controle Biológico da broca da cana-de-açúcar. Manual de Instrução. Piracicaba, IAAPLANALSUCAR. $22 \mathrm{p}$.

MANGAT, B.S., 1970. Rearing the black cutworm in the laboratory. Journal of Economic Entomology. Geneva, 63: 1325-1326.

MARTINS, J.F.S., 1983. Resistência de variedades de arroz à Diatraea saccharalis (Fabricius, 1794) (Lepidoptera-Pyralidae) e sua associação com características biofísicas e bioquímicas das plantas. Piracicaba, ESALQ/USP, 139p. [Tese de Doutoramento] .

MELO, A.B.P., 1984. Biologia de Diatraea saccharalis (Fabricius, 1794) (Lepidoptera-Pyralidae) em diferentes temperaturas para determinação das exigências térmicas. Piracicaba, ESALQ/ USP, 101p. [Dissertação de Mestrado].

MENDES, A.C., 1980. Métodos de criação de parasitos da broca: da cana-de-açúcar, Diatraea saccharalis (Fabricius, 1794). In: Anais do VI Congresso Brasileiro de Entomologia. Campinas, $103-132$. 
MENDES, A.C.; P.S.M. BOTELHO e N. MACEDO, 1977. Estudos comparativos de novos substratos para a oviposilão de Diatraea saccharalis (Fabr., 1794) (Lep.: Crambidae) em condições de 1aboratório. Brasil Açucareiro. Rio de Janeiro, 87(6): 73-77 .

MENDONÇA FILHO, A., 1973. Criação artificial em laboratório dos parasitos da broca da cana-de-açúcar (Diatraea spp.) (Lep., Crambidae). Brasil Açucareiro. Rio de Janeiro, 81(4): $47-80$.

MISKIMEN, G.W., 1965. Nonaseptic laboratory rearing of the sugarcane borer, Diatraea saccharalis. Annals of the Entomological Society of America. Columbus, 58(6): 820-823.

MORAES, G.J. e D. GALLO, 1976. Contribuição a metodologia de criação de Diatraoa saccharalis. In: Resumo do II Congresso de Entomologia, Maceiô, p.157.

NOVARETTI, W.R. e F.O. TERAN, 1976. Melhorias introduzidas nas dietas usadas para a criação da Diatraea saccharalis (Fabr., 1794). In: Anais do IV Seminärio COPERSUCAR da Agroindústria Açucareira. São Paulo, p.81-84.

PAN,Y. e W.H. LONG, 1961. Diets for rearing the sugarcane borer. Journal of Economic Entomology. Geneva, 54 (2): 257-261. 
PARRA, J.R.P., 1979, Biologia dos Insetos. Piracicaba, ESALQ. 383p. [mimeografado].

POITOUT, S. e R. BUES, 1970. Elevage de plusieurs espèces de lépidoptères Noctuidae sur milieu artificiel riche et sur milieu artificial simplifié. Annales de Zoologie. Ecologie. Paris, 2: 79-91.

RISCO, S.H.; N. MORALES e G. AYQUIPA, 1973. Una dieta para la crianza masiva de orugas del borer de la caña de azücar: Diatraea saccharalis (Fabr.) (Lep.: Crambidae). Saccharum. São Paulo, 1(1): 27-42.

ROE, R.M.; A.M. HAMMOND e T.C. SPARKS, 1982. Growth of larval Diatraea saccharalis (Lepidoptera: Pyralidae) on an artificial diet and synchronization of the last larval stadium. Annals of the Entomological Society of America. Columbus, 75(4): $421-429$.

SANFORD, J.W., 1971. A comparison of 3 artificial diets for the sugarcane borer. In: Proceedings of the International Society of Sugar Cane Technologists. New Orleans, 14: 462-465 . 
SANTA CRUZ, J.M.S.; C.S. MOSS; G.G. RANAUD e C.G. MONTALVO, 1964. Cria artificial de Diatraea saccharalis Fab. (Lepidoptera: Pyralidae) y su aplicación en la evolución de résistencia en má̃z. Agrociência. México, 18: 3-13.

SGRILLO, R.B., 1973. Criação em laboratório da broca da cana-de-açúcar [Diatraea saccharalis (Fabrius, 1794)] visando seu controle. Piracicaba, ESALQ/USP, 98p. [Dissertação de Mestrado].

SGRILLO, R.B.; J.M.M. WALDER e F.M. WIENDL, 1976. Progressos na criação da broca da cana-de-açúcar, Diatraea saccharalis (F.) realizados no Centro de Energia Nuclear na Agricultura CENA. O Solo. Piracicaba, 69(1): 58-60.

SILVA, W.J.; J.P.F. TEIXEIRA; P. ARRUDA e M.B. LOVATO, 1978. Nutrimais, a tropical sweet maize cultivar of high nutritional value. Maydica, 23: 129-136.

SILVEIRA NETO, S.; O. NAKANO; D. BARBIN e N.A. VILLA NOVA, 1976. Manual de Ecologia dos Insetos. São Paulo. Ed. Agronômica Ceres. $419 \mathrm{p}$.

SINGH, P., 1977. Artificial diets for insects, mites and spiders. IFI/Plenum, New York, 718p. 
SINGH, P., 1983. A general purpose laboratory diet mixture for rearing insects. Insects Science Application. Grã-Bretanha, $4(4): 357-362$.

SNEATH, P.H.A. e R.R. SOYKAL, 1973. Numerical Taxonomy. San Francisco, W.H. Freeman. 573p.

TERAN, F.O., 1980. Criação de parasitos de Diatraea saccharalis (Fabricius, 1794). In: Anais do VI Congresso Brasileiro de Entomologia. Campinas, p.133-140.

TOSELLO, G.A., 1980. Milhos especiais e seu valor nutritivo. In: PATERNIANI, E., Coord. Melhoramento e produção do milho no Brasil. Piracicaba/ESALQ, Ed. Marprint. 650p.

VAN DINTHER, J.B.M. e P.A. GOOSSENS, 1970. Rearing of Diatraea saccharalis on diets in Surinam. Entomologia Experimentalis et Applicata. Amsterdam, 13: 320-326.

VILlACORTA, A. e J.A. MAGRO, 1975. Criação massal de Diatraea saccharalis (Lepidoptera: Pyralidae) em laboratório. Anais da Sociedade Entomológica do Brasil. Jaboticabal, $\underline{4}(1)$ : $43-48$. 
WALDBAUER, G.P., 1968. The consumption and utilization of food by insects. Advances in Insect Physiology. London, 5: 229-288 .

WALDER, J.M.M.; V. ARTHUR; R.E. DOMARCO; F.M. WIENDL e R.B. SGRILLO, 1976. Uma nova dieta para criação de lagartas de Diatraca saccharalis (F.). In: Resumo do III Congresso Brasileiro de Entomologia, Maceió. p.159.

WALKER, D.W., 1968. Potential for control of sugarcane borer through radio-induced sterility. In: Radiation, radioisotopes and rearing methods in control of insects pests. Proceedings of a Painel. Tel-Aviv, IAEA, p.131-140.

WALKER, D.W.; A.V. ALEMANY; V. QUINTANA; F. PADOVANI e K.S. HAGEN, 1966. Improved xenic diets for rearing the sugarcane borer in Puerto Rico. Journal of Economic Entomology. Geneva, $59(1): 1-4$.

WONGSIRI, T. e N.M. RANDOLPH, 1962. A comparison of the biology of the sugarcane borer on artificial and natural diets. Journal of Economic Entomology. Geneva, 55(4): 472-473. 